University of Louisville

ThinkIR: The University of Louisville's Institutional Repository

$12-2005$

\title{
Origins of imperial Ottoman architecture in Istanbul : a cross- cultural interpretation on the development of a new Classical tradition.
}

Shannon P. Carneal

University of Louisville

Follow this and additional works at: https://ir.library.louisville.edu/etd

\section{Recommended Citation}

Carneal, Shannon P., "Origins of imperial Ottoman architecture in Istanbul : a cross-cultural interpretation on the development of a new Classical tradition." (2005). Electronic Theses and Dissertations. Paper 211. https://doi.org/10.18297/etd/211

This Master's Thesis is brought to you for free and open access by ThinkIR: The University of Louisville's Institutional Repository. It has been accepted for inclusion in Electronic Theses and Dissertations by an authorized administrator of ThinkIR: The University of Louisville's Institutional Repository. This title appears here courtesy of the author, who has retained all other copyrights. For more information, please contact thinkir@louisville.edu. 
ORIGINS OF IMPERIAL OTTOMAN ARCHITECTURE IN ISTANBUL:

A CROSS-CULTURAL INTERPRETATION ON THE DEVELOPMENT OF A NEW CLASSICAL TRADITION

UNIVERSITY OF LOUISVILLE

A THESIS SUBMITTED TO

THE FACULTY OF THE GRADUATE SCHOOL

IN CANDIDACY FOR THE DEGREE OF

MASTER OF ARTS

DEPARTMENT OF FINE ARTS

BY

SHANNON P. CARNEAL

LOUISVILLE, KENTUCKY

DECEMBER 2005 
Copyright 2005 by Shannon P. Carneal

All rights reserved 
ORIGINS OF IMPERIAL OTTOMAN ARCHITECTURE IN ISTANBUL:

A CROSS-CULTURAL INTERPRETATION ON THE DEVELOPMENT OF A NEW CLASSICAL TRADITION

\section{By}

Shannon P. Carneal

B.A., Bellarmine University, 1999

A Thesis Approved on

December 05, 2005

by the following Thesis Committee:

Thesis Advisor 


\section{DEDICATION}

This thesis is dedicated to my parents

$$
\text { Mr. James W. Carneal Jr. }
$$

and

Mrs. Penney Carneal

who have supported me in my academic endeavors. 


\section{ACKNOWLEDGMENTS}

I would like to thank my professor and advisor, $\mathrm{Dr}$. Karen Britt, for her guidance and instruction. I would also like to thank the other committee members, Dr. Linda Gigante, Dr. Justin McCarthy, and Dr. Christopher Fulton, for their time and invaluable input. I also extend my appreciation to Dr. Jonathan Bloom for his help in setting my research in the right direction. My sincerest gratitude to Mrs. Sheridan, my Humanities teacher at Ballard High School, without whom I may have never developed an appreciation for art. 


\title{
ABSTRACT
}

ORIGINS OF IMPERIAL OTTOMAN ARCHITECTURE IN ISTANBUL: A CROSS-CULTURAL INTERPRETATION ON THE DEVELOPMENT OF A NEW CLASSICAL TRADITION

\author{
Shannon P. Carneal
}

December 15,2005

Following the conquest of Constantinople in 1453 by the Ottomans, a new trend in architecture developed that achieved a balance between the traditional ottoman building practices of Bursa and Edirne with the styles found in Byzantium and the West. This thesis uncovers what led to the creation of a new Classical Ottoman architecture through an examination of the architectural resources available to the Ottoman sultans and their architects. The goal of this thesis is to discover what, if anything, is ottoman about ottoman imperial architecture in Istanbul.

Was this new architecture the result of a logical progression of a traditional style or was it influenced by the new availability of Byzantine and Western resources? Sinan, chief architect under sultan suileyman, attained a mastery of material and visual harmony in his silleymaniye Mosque Complex. Through a chronological study of his earlier mosques and the mosques of his predecessors, I intend to show the mosques of Sinan were responses to cross-cultural 
influences. Since mosque architecture is not restricted by plan requirements, almost any structure regardless of form may be converted to mosque use. This means that mosque construction is not limited to a particular style and therefore may be adapted to exist as a composite of building traditions.

I consulted historical accounts and recent scholarship regarding Ottoman architectural history, along with associated myths and legends concerning the appropriation of the Byzantine Church of Hagia Sophia for Ottoman worship. I also compiled comparison data and statistics on the physical characteristics and dimensions of the mosques including plans and layout, and construction and decoration techniques. 
TABLE OF CONTENTS

PAGE

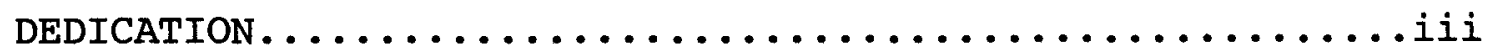
ACKNOWLEDGMENTS ............................. . . . . . .

ABSTRACT. ..............................

LIST OF FIGURES..............................

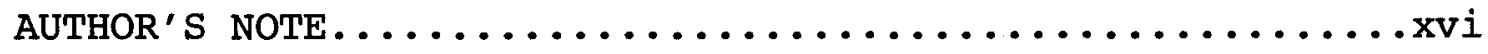

\section{CHAPTER}

I. INTRODUCTION. ..........................

II. BIRTH OF THE OTTOMAN MOSQUE.................. 5

Mosque of the Prophet....................

Turkish Mosques........................

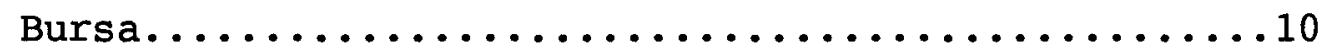

Yesil Camii.............................11

Edirne................................ 18

Üç Serefeli Camii......................... 20

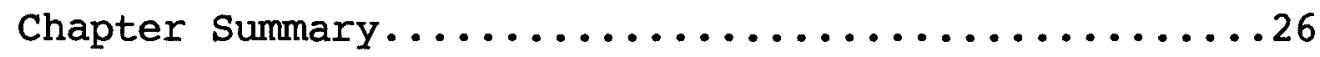

III. BYZANTINE CHURCH CONSTRUCTION. ................28

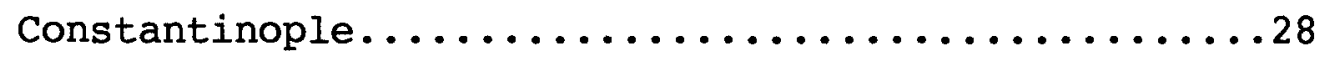

ss sergius and Bacchus..........................

Hagia Sophia............................. 34

Constantine Lips........................41

Theotokos Pammakaristos.................... 44

Chapter summary........................47

IV. WHEN THE WEST MOVED EAST. .....................49

The Early Years of Sultan Mehmed II.............49

The Art of Conquest..................... 50

Renaissance and the East...................... 55 
Legacy of the fâtih....................63

Chapter summary........................63

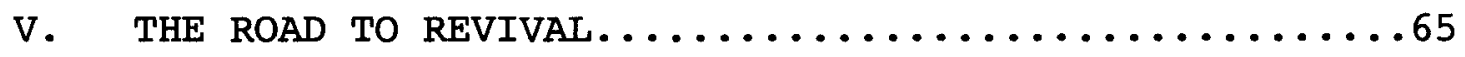

staking claims.........................65

Ayasofya Camii.........................66

Küçük Ayasofya Camii.......................69 69

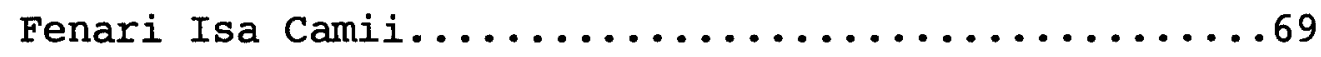

Fethiye Camii.......................... 70

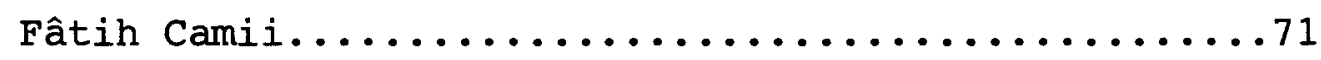

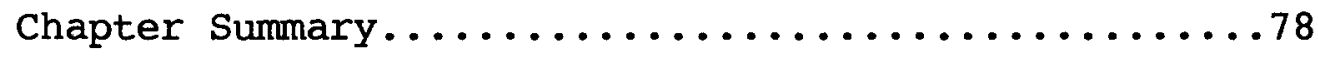

VI. THE RISE OF CLASSICAL OTTOMAN ARCHITECTURE........79

Sultan Bayezid II Camii.............................

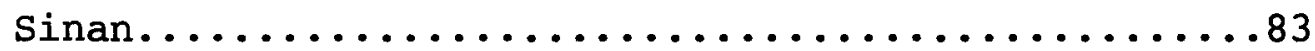

Sehzade Camii........................... 84

Sïleymaniye Camii........................88

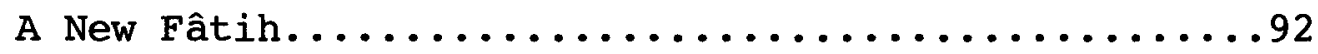

VII. THE OTTOMAN ARCHITECTURAL CONQUEST OF CONSTANTINOPLE.95

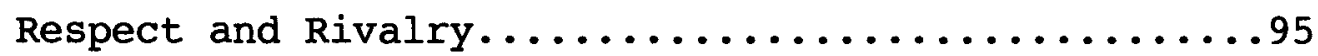

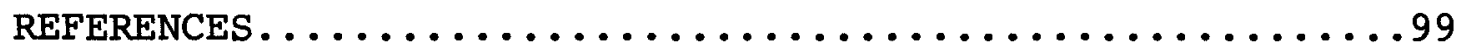

CURRICULUM VITAE............................ 106 


\section{LIST OF FIGURES}

FIGURE

PAGE

1. House of the Prophet, Medina..................

Plan After R. Ettinghausen, Islamic Art and

Architecture 650-1250 (New Haven, 2001)

2. Great Mosque, Sivas.......................8

View of Prayer Hall From Archnet,

<http://archnet.org>

3. Great Mosque, Diyarbakir.....................8

View of Prayer Hall From Archnet,

<http: //archnet.org>

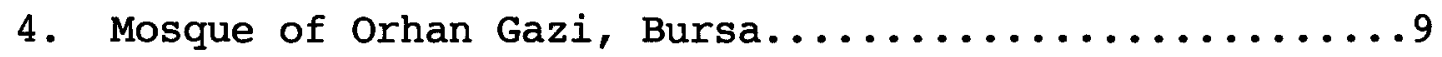

Plan From Archnet, <http://archnet.org>

5. Mosque of Murad I, Bursa...................... 10

Plan From Archnet, <http://archnet.org>

6. Yesil Camii, Bursa.........................11

Exterior From Archnet, <http://archnet.org>

7. Great Mosque of Isfahan, Iran...................

Courtyard and Iwans From Archnet,

<http://archnet.org>

8. Great Mosque of Isfahan, Iran.....................

Plan From G. Michell, Architecture of the Islamic

World (London, 1978)

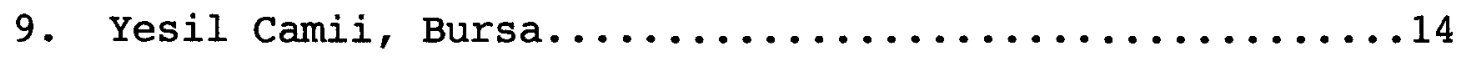

Floor Plan of Ground Level From Archnet,

<http: //archnet.org> 
10. Yesil Camii, Bursa......................... 15

Interior View Toward Prayer Hall From Archnet, <http://archnet.org>

11. Yesil Camii, Bursa.......................

Interior Detail of Tilework From Archnet, <http://archnet.org>

12. Yesil Camii, Bursa.......................

Façade Showing Arch Springs From Archnet,

<http://archnet.org>

13. Yesil Camii, Bursa.......................

Floor Plan of Gallery Level From Archnet,

<http://archnet.org>

14. Yesil Camii, Bursa....................... 18

Sultan's Lodge From Archnet,

<http://archnet.org>

15. Selimiye Camii, Edirne.................... 19

Plan after G. Goodwin, ottoman Turkey (London, 1977)

16. Selimiye Camii, Edirne........................

Exterior From Archnet, <http://archnet.org>

17. Üç Serefeli Camii, Edirne................... 20

Floor Plan After G. Goodwin, Ottoman Turkey

(London, 1977)

18. Üç Serefeli Camii, Edirne..................

Interior View Toward Qibla From Archnet,

<http://archnet.org>

19. Üç Serefeli Camii, Edirne..................22

Courtyard From Archnet, <http://archnet.org>

20. Üç Serefeli Camii, Edirne...................

Detail of Tile-work From Archnet,

<http://archnet.org>

21. Üç Serefeli Camii, Edirne...................24 
Main Portal From Archnet, <http://archnet.org>

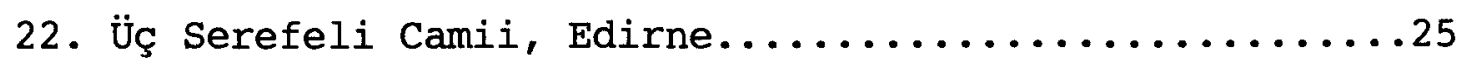

Exterior From Archnet, <http://archnet.org>

23. Ü̧̇ Serefeli Camii, Edirne...................... 25

Exterior After S. Blair and J. Bloom, The Art and

Architecture of Islam 1250-1800 (New Haven, 1994)

24. Map of Byzantine Empire 633...................29

Map After $W$. Treadgold, A History of the Byzantine

State and Society (Stanford, 1997)

25. Map of Byzantine Empire 1282...................29

Map After W. Treadgold, A History of the Byzantine

State and Society (Stanford, 1997)

26. Ss Sergius and Bacchus, Constantinople............31

Plan After W. Müller-Wiener, Bildlexikon Zur

Topographie Istanbuls (Germany, 1977)

27. Ss Sergius and Bacchus, Constantinople.................

Plans and Exterior After R. Krautheimer, Early

Christian and Byzantine Architecture (New York, 1986)

28. Ss Sergius and Bacchus, Constantinople............32

Exterior From Archnet, <http://archnet.org>

29. SS Sergius and Bacchus, Constantinople................

Plan From Archnet, <http://archnet.org>

30. Hagia Sophia, Constantinople...................... 36

Plan After G. Necipoglu, Age of Sinan: Architectural

Culture in the ottoman Empire (Princeton, 2005)

31. Hagia Sophia, Constantinople.......................

Exterior From Archnet, <http://archnet.org>

32. Hagia Sophia, Constantinople........................

Apse Semi-dome and Central Dome From Archnet,

<http://archnet.org> 
33. Hagia Sophia, Constantinople.................. 39

Interior Central Dome From Archnet,

<http://archnet.org>

34. Hagia Sophia, Constantinople...................40

Inner Narthex and Imperial Door From Archnet,

<http://archnet.org>

35. Hagia Sophia, Constantinople..................40

Interior View of Nave Toward the Apse From Archnet,

$<$ http: //archnet.org>

36. Constantine Lips, Constantinople.................42

Ground Floor and Gallery Plans After R. Ousterhout,

Master Builders of Byzantium (Princeton, 1999)

37. Constantine Lips, Constantinople.................43

Plan After R. Ousterhout, Master Builders of Byzantium

(Princeton, 1999)

38. Theotokos Pammakaristos, Constantinople...........44

Plan After R. Ousterhout, Master Builders of Byzantium

(Princeton, 1999)

39. Theotokos Pammakaristos, Constantinople..........45

Exterior Facing Parekklesion From Archnet,

<http: //archnet.org>

40. Theotokos Pammakaristos, Constantinople..........46

Interior of Parekklesion From Archnet,

<http: //archnet.org>

41. Fâtih Complex, Istanbul..................... 56

Plan After G. Necipoglu, Age of Sinan: Architectural

Culture in the ottoman Empire (Princeton, 2005)

42. Ospedale Maggiore, Milan....................57

Plan and Elevation After G. Necipoglu, Age of Sinan:

Architectural Culture in the ottoman Empire 
(Princeton, 2005)

43. St. Peter's, Rome...................... 58

Medal Depicting Elevation After G. Necipoglu, Age of

Sinan: Architectural Culture in the Ottoman Empire

(Princeton, 2005)

44. St. Peter's, Rome..........................

Plans After G. Necipoglu, Age of Sinan: Architectural

Culture in the Ottoman Empire (Princeton, 2005)

45. St. Peter's Rome......................60

Michelangelo's Plan and Elevation After G. Necipoglu,

Age of Sinan: Architectural Culture in the ottoman

Empire (Princeton, 2005)

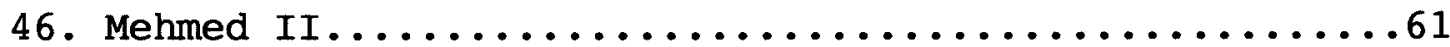

Medals by Costanzo de Ferrara and Bernini After G.

Necipoglu, Age of Sinan: Architectural Culture in

the Ottoman Empire (Princeton, 2005)

47. Fâtih Camii, Istanbul....................

Elevation Drawing After G. Necipoglu, Age of Sinan:

Architectural Culture in the Ottoman Empire

(Princeton, 2005)

48. Fâtih Camii, Istanbul....................

Plan From Archnet, <http://archnet.org>

49. Fâtih Camii, Istanbul.....................

Main Portal From Archnet, <http://archnet.org>

50. Sultan Bayezid II Camii, Istanbul..............79

Exterior From Archnet, <http://archnet.org>

51. Sultan Bayezid II Camii, Istanbul............. 80

Plan From Archnet, <http://archnet.org>

52. Sultan Bayezid II Camii, Istanbul.............

View of Façade From Courtyard From Archnet, 
<http: //archnet.org>

53. Sultan Bayezid II Camii, Istanbul...............81

Interior View of Central Dome and Semi-domes From

Archnet, <http://archnet.org>

54. Sultan Bayezid II Camii, Istanbul..............82

Interior Looking Toward Qibla From Archnet,

<http://archnet.org>

55. Sehzade Camii, Istanbul.....................85

Plan After G. Goodwin, A History of Ottoman

Architecture (Baltimore, 1971)

56. Sehzade Camii, Istanbul....................86

Exterior From ArtServe <http://rubens.anu.edu.au>

57. Sehzade Camii, Istanbul....................87

Exterior After G. Necipoglu, Age of Sinan:

Architectural culture in the Ottoman Empire

(Princeton, 2005)

58. Süleymaniye Camii, Istanbul..................88

Exterior From ArtServe <http://rubens.anu.edu.au>

59. Süleymaniye Camii, Istanbul...................89

Interior of Central Dome and Semi-domes After

G. Necipoglu, Age of Sinan: Architectural Culture

in the Ottoman Empire (Princeton, 2005)

60. Süleymaniye Camii, Istanbul..................90

Plan After G. Goodwin, A History of Ottoman

Architecture (Baltimore, 1971)

61. Silleymaniye Camii, Istanbul.................91

Interior of Prayer Hall From John S. Murray

Photography

<http://johnsmurrayphotography.homestead.com>

62. Süleymaniye Camii, Istanbul..................91 
Interior After G. Necipoglu, Age of Sinan:

Architectural Culture in the ottoman Empire

(Princeton, 2005)

63. Fâtih Camii, Istanbul.......................

Exterior From Archnet <http://archnet.org>

64. Fâtih Camii, Istanbul.....................

Plan From Archnet <http://archnet.org>

65. Fâtih Camii, Istanbul....................... 94

Interior of Domed Superstructure From Archnet

<http://archnet.org>

66. Transformation of Mosque Plans................

Plans After G. Necipoglu, Age of Sinan: Architectural

Culture in the Ottoman Empire (Princeton, 2005)

67. Süleymaniye Camii, Istanbul................98

View of Façade From Courtyard After G. Necipoglu,

Age of Sinan: Architectural Culture in the Ottoman

Empire (Princeton, 2005) 


\section{AUTHOR'S NOTE}

Turkish Characters, Pronunciation, and Spelling The lack of a standard Turkish to English transliteration leads to a variety of alternate spellings. Some authors elect to write phonetically, but I have chosen to use Turkish characters in the spelling of words and names whenever possible. For formatting reasons however, in this paper the cedilla (,) has been removed from the $S$ in Pasa, Serefeli, serefe, sadirvan, Sehzade, and Yesil, but the pronunciation remains sh in these words. In a few cases I have chosen to spell out familiar Turkish words in the Western manner, as in the cases of Istanbul and Iznik.

Some Turkish to English pronunciations

Ç is pronounced $c h$ as in church

C is pronounced $j$ as in jury

s with cedilla is pronounced sh as in shuffle

The name Mehmed is often found in sources written as Mehmet while Bayezid, as I have chosen to spell it, is frequently written as Beyazid, Bayezit, Beyazit, or even Bayazid. 
CHAPTER I

INTRODUCTION

There are two primary schools of thought in the debate over the origin of 16 th century Classical Ottoman mosque architecture. One group subscribes to the theory that the new architectural style developed from a logical progression of traditional ottoman planning and design. The opposing side relies heavily on the belief that the presence of the Byzantine church of Hagia Sophia had a significant impact on future construction within Constantinople. There is a third possible influence which is frequently omitted from the rivalry of those first two theories but offers a similarly valid argument. Sultan Mehmed II Fâtih ( $r$. 1444-5 and 145181), the Ottoman conqueror of Constantinople, is credited with leading the reconstruction of the city and opening the path toward a new architecture. Not only did he have knowledge of early Ottoman building techniques and the Byzantine structures newly available to him in the city but, as a connoisseur and collector of Western European arts and literature, he had a substantial knowledge of Renaissance practices as well. As the first sultan of Istanbul, his imperial patronage provided the foundation upon which the future of the Ottoman Empire was created both politically and artistically.

To determine the validity of each theory this thesis will examine the prevalent building traditions of the 
Ottomans (1281-1924) in their early capitals of Bursa and Edirne, and those of the Byzantines in Constantinople, and within the imperial city created by Mehmed II. An analysis of the works of Sinan, the preeminent ottoman architect of the 16th century credited with the creation of the Classical Ottoman style, will provide the documentation from which the evidence for the prevailing theories will be gathered.

Traditional Ottoman architecture has Anatolian Selçuk roots. The early ottoman capital of Bursa (1326-1403) is home to several selçuk inspired mosques, the most famous being the Yesil Camii (Green Mosque) built around 1419. This mosque is an example of the standard by which other mosques were to be measured. Its traditional style marked the point of departure into the multiunit style found in Ottoman cities thereafter. Edirne became the Ottoman capital after the loss of Bursa in 1403. The Üç Serefeli Camii (Three Balconied Mosque), built between 1437-1447, is considered by many to be the precursor to the domed multiunit mosques of Istanbul because it melds traditional styles with the innovations of the future. Did the Muslims have the same commitment to Islamic architectural tradition as they did to their faith?

The Byzantines were prodigious builders and their monuments to Christianity stood for centuries, both in Constantinople and beyond, well before the Ottoman invasion of the city. The domed Byzantine churches of SS Sergius and Bacchus (527-536), Constantine Lips (908), Theotokos Pammakaristos (12th century), and the jewel of the Empire, Hagia Sophia (532-537), could have been known to the Ottomans before 1453 but they were undoubtedly made evident to them upon their arrival in Constantinople. These esteemed churches of Byzantium survived nearly intact throughout the 
almost 500 years of Ottoman occupation of the city and, therefore, must have been regarded with some significance by the Ottomans themselves. Was it the architecture or the symbolic associations of power and religion that saved the churches of Constantinople from destruction?

Sultan Mehmed II Fâtih (r. 1451-1481) was highly educated. He thirsted for vast cultural knowledge and amassed a library of books and artwork from both the East and the West. He governed the Ottoman empire from Istanbul for nearly 30 years, imposing his will upon both the people and the land they occupied. As the founder of the Islamic city of Istanbul, he laid the foundation from which the future of the empire would develop. Did his desire for the goods and services of the West spill from private admiration and collection to public display and construction?

The mosques of Mehmed II Fâtih and his successors reached a zenith in the work of sinan culminating in the development of a new classical style. An understanding of the Fâtih Mosque (1463-1470), located within the first imperial mosque complex of Istanbul, and the Beyazid II Mosque (1500-1505) is central to interpreting the works of Sinan. Sinan, the undisputed master of ottoman architecture, remade the skyline of Istanbul with his Sehzade Mosque (15431548), a so-called work of his apprenticeship and the Silleymaniye Mosque (1550-1557), his masterpiece for Sultan Süleyman (r. 1520-1566).

The creation of a new empire led to the creation of a new architecture. Was this a systematic development of a traditional style or was it influenced by the new availability of Byzantine and Western resources? Sinan, chief architect under sultan Süleyman, achieved a mastery of 
material and visual harmony in his Süleymaniye Mosque Complex. Through a chronological study of one of his earlier mosques and the mosques of his predecessors, I intend to show that the mosques of Sinan were responses to cross-cultural influences culminating in a new Classical Ottoman tradition best exemplified by the 16 th century Süleymaniye Mosque Complex. 
CHAPTER II

BIRTH OF THE OTTOMAN MOSQUE

\section{Mosque of the Prophet}

In 622, the Prophet Mohammed gathered adherents to the new faith at his home in Medina, Arabia. That domestic building became the first Islamic mosque. Plans of future mosques tend to incorporate elements based on the ritual of worship that occurred there, as well as the general design of the building. At the time of his death in 1481, Mohammed had not laid down any rules governing the creation of mosque architecture either in the Qur'an or his other correspondence. Without any documentation, mosque form was open to interpretation. ${ }^{1}$

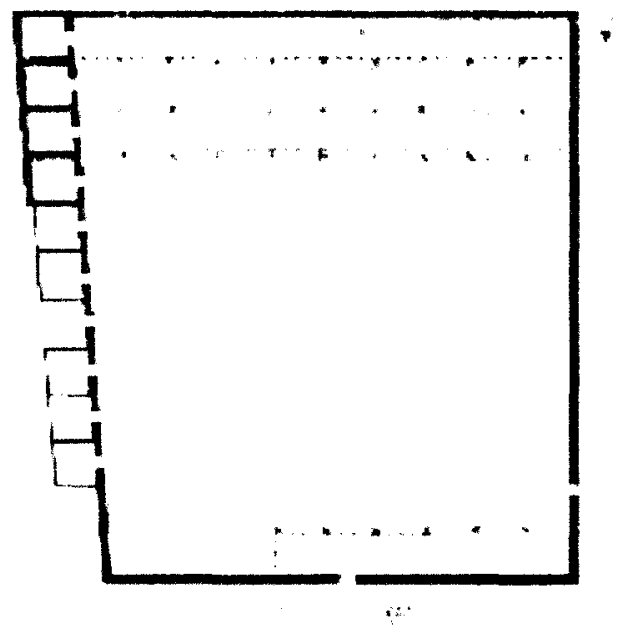

Figure 1. Mosque of the Prophet, Medina (622) Plan.

Richard Ettinghausen, Oleg Grabar, and Marilyn Jenkins-Madina, The Art and Architecture of Islam, 650-1250, 2nd ed. (New Haven: Yale University Press, 2001) 3-5. 
Mohammed's house was a simple rectangular structure nearly 50 by 50 meters made of sun baked bricks. The building was inward facing with a large courtyard and private rooms hidden from view by the surrounding exterior walls. Along the southern wall of the courtyard a covered area was built for protection against the sun. This area was supported by rows of columns made of palm trunks and was covered by thatches of palm leaves. This hypostyle hall was where the faithful gathered to hear the sermons given by the Prophet. The southern wall of the complex served as the qibla, denoting the direction toward which the faithful were to pray. The small pulpit from which Mohammed led services was called a minbar, the name given to a judge's seat. ${ }^{2}$

Based upon the prototype of the Prophet's house, the minimum requirements for mosques came to include a mihrab along the qibla wall which indicates the direction of Mecca; a minbar from which the imam gives the sermon in congregational mosques; and a prayer hall where the faithful gather in rows to prostrate themselves in prayer. An elevated place from which to issue the call to prayer, usually a tower (minaret), became a requirement as did a fountain for cleansing (ablution fountain). The mosque form in its most elementary state became a covered sanctuary preceded by a courtyard with the size, shape and design being variable features. ${ }^{3}$

Since mosque architecture is not restricted by plan requirements, almost any structure regardless of form may be converted to mosque use. This means that mosque construction is not limited to a particular style and therefore may be

\footnotetext{
Ettinghausen 3-5.

${ }^{3}$ Dogan Kuban, Muslim Religious Architecture Part I: The Mosque and its Early Development (Leiden: E. J. Brill, 1974) 1-3.
} 
adapted to exist as a composite of several building traditions. Mosque architects are thus able to draw on a vast array of building traditions in their design of new mosques. Also, buildings which traditionally serve other functions can be easily converted to use as a mosque. Large congregational mosques are built to house the masses that assemble communally for Friday prayers. Daily prayers may be held anywhere, indoors or out, but are frequently attended in smaller neighborhood mosques." This thesis concentrates on the imperial construction of congregational mosques in the three Ottoman capitals of Bursa, Edirne, and Istanbul.

Mosque decoration is more restrictive than mosque design. No figural representations may be on display in the religious structures. Secular Islamic art, on the other hand, includes images which depict figural representations. Islam very clearly prohibits idols, as do other religions, but somehow this fundamental boundary was translated into an opposition to all figural representations in religious art. For this reason Qur'anic inscriptions, geometric patterns, and floral and vegetal motifs are extremely popular decorative designs. In the conversion of existing buildings to mosques during the ottoman period, the structures themselves were often kept intact despite the necessity of being subjected to defacement and whitewashing, common methods for the removal of existing figural elements. ${ }^{5}$

\footnotetext{
Kuban, Muslim Religious Architecture Part I 1-3.

${ }^{5}$ Ettinghausen 5-7.
} 
The earliest Turkish mosques were constructed as simple hypostyle halls following the prototype of the Prophet's house in Medina.

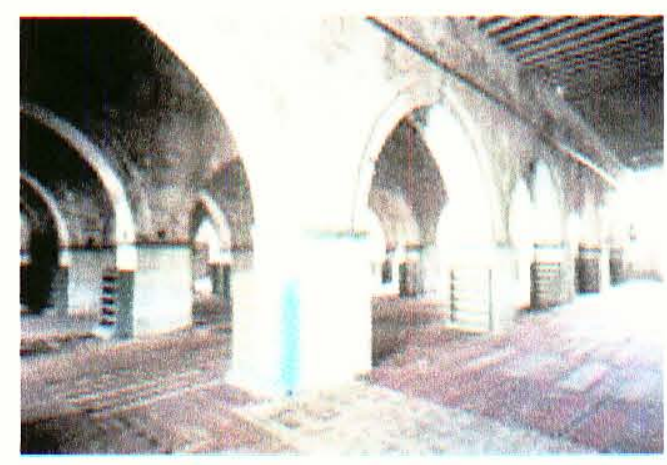

Figure 2. Great Mosque, Sivas (1197) View of prayer hall.

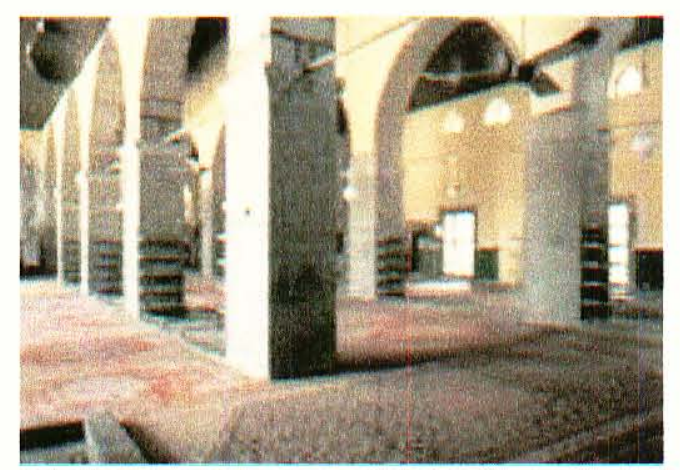

Figure 3. Great Mosque, Diyarbakir (1091) View of prayer hall.

Deviation from this plan occurred under the Anatolian Selçuks (1071-1300) who dispensed with the preceding courtyard in their mosque designs. ${ }^{6}$

Anatolia was united under the Selçuks of Rum until around 1300. At this point, the region split into many smaller tribal factions of which the Ottomans became the most successful. These tribes, when discussed as a group, are ${ }^{6}$ Dogan Kuban, Muslim Religious Architecture Part II: Development of Religious Architecture in Later Periods (Leiden: E. J. Brill, 1985) 19 . 
referred to as the Beyliks. While the Selçuk buildings in Iran were built of brick, Ottoman buildings which followed the Anatolian Selçuk tradition were built of stone." ${ }^{7}$ The Selçuk mosques were richly decorated with stone carvings, tiled mosaics, and painted woodwork. The mosques were rectangular in shape with multi-bay porches. A small domed entryway led into a domed central hall which contained a pool beneath an oculus. Beyond the central court was a raised platform which contained the qibla and served as the mosque proper. The sides of the court were surrounded by smaller iwans (covered halls) which served as hostels and meeting rooms. Examples of Selçuk mosques include the Mosques of Orhan Gazi (1339) and Murad I (1366-85) in Bursa. ${ }^{8}$

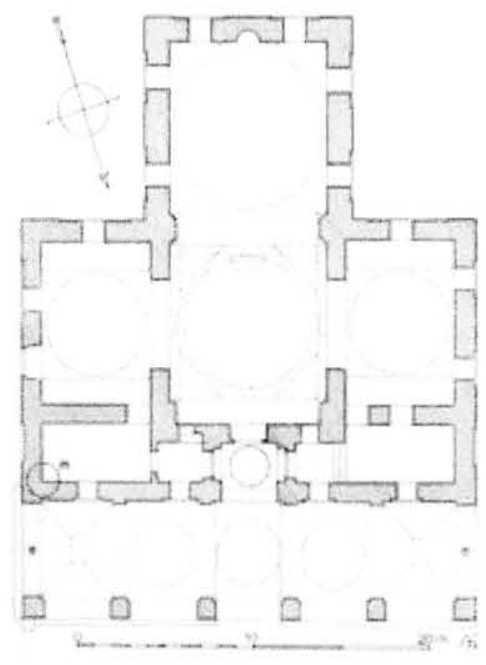

Figure 4. Orhan Gazi Mosque, Bursa (1339) Plan.

\footnotetext{
"Aptullah Kuran, "Turkish Architecture, Past and Present: A Brief Account," Conservation as Cultural Survival, Ed. Renata Holod (Philadelphia: The Aga Khan Award for Architecture, 1980) 82. <http://archnet.org/library/documents/onedocument.tcl?document_id=2605>.

${ }^{8}$ Sheila S. Blair and Jonathan M. Bloom, The Art and Architecture of Islam 1250-1800 (New Haven: Yale University Press, 1994) 132-138.
} 
Figure 5. Mosque of Murad I, Bursa (1366-85) Plan.

It is from this Selçuk tradition that the Ottoman mosque plan developed. Early Ottoman mosque construction was divided between two interpretations of mosque design. The first style is a close adherent to the Anatolian Selçuk tradition of creating multipurpose mosques, the best example of which is the Yesil Camii in Bursa. The second approach developed from the "old scheme of a mosque with a domed maqsura and a courtyard culminating in the mosque of Üç Serefeli in Edirne." ${ }^{9}$

\section{Bursa}

Bursa (Brusa) is located just south of Constantinople across the Sea of Marmara. After Bursa was captured by the Ottomans, it became their first capital. The city remained the seat of imperial power from 1326 to 1403, when an opposing Beylik tribe headed by Timur finally captured the city from the Ottomans. The Ottoman defeat, however, did not ${ }^{9}$ Kuban, Muslim Religious Architecture Part II 20-21. 
mean the end of architectural advancements and Ottoman influence within the city. The son of the defeated Sultan Bayezid I recaptured Bursa and the other provinces of Anatolia by $1413 .^{10}$

\section{Yesil Camii}

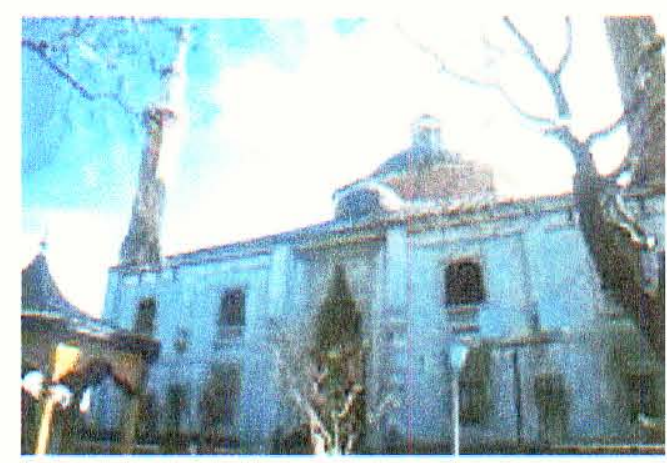

Figure 6. Yesil Camii, Bursa (1419-21) Exterior.

The Yesil Camii (Green Mosque) at Bursa melds the architecture of the Selçuks with other early Ottoman influences. Constructed between 1419 and 1421 by architect Haci Ivaz Pasa under Sultan Mehmed I, the design of the building incorporates several independent spaces with only the largest central space devoted to mosque use. ${ }^{11}$ In a career move similar to that of Sinan in the sixteenth century, Haci Ivaz (bin Ahi Beyazit) Pasa first served as an army commander under Bayezid I and Mehmed I before being called upon to serve as Mehmed's architect and then becoming a vizier. He used the services of Persian craftsmen to aid the construction of the Yesil Camii and "sought to improve the architecture of the empire by bringing into the capital artists and artisans from different regions of the Islamic

\footnotetext{
Blair and Bloom 141-142.

${ }^{11}$ Kuban, Muslim Religious Architecture Part II 21.
} 
world". ${ }^{12}$ Like the great mosques to follow, the Yesil Camii was built atop a hill from where it dominated the landscape. ${ }^{13}$ The Yesil Camii was built in the Anatolian Selçuk tradition of the four-iwan plan. After its use in Bursa it also became known as the cruciform, reverse T-shaped, cross-axial, or the Bursa plan. ${ }^{14}$

A good surviving example of the Selçuk four-iwan plan is the Great Mosque of Isfahan in Iran. Though the complex has undergone many distinct periods of construction and endured a wide variety of additions, at the heart of it all is the Selçuk four-iwan plan in which the four large vaulted halls face onto an open courtyard.

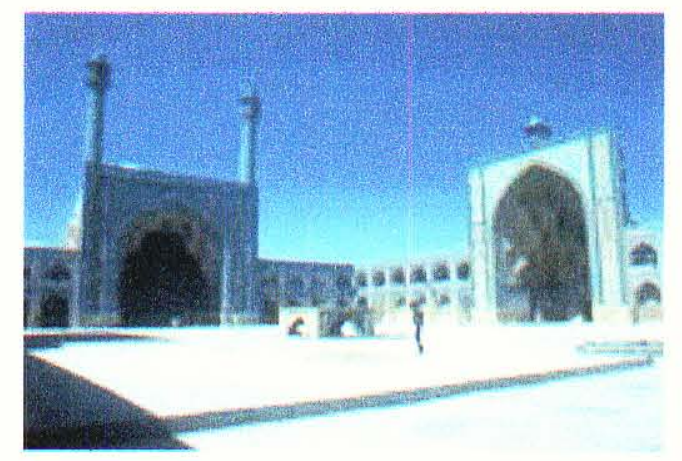

Figure 7. Great Mosque of Isfahan, Iran (8th-17th C.) Courtyard and iwans.

\footnotetext{
12 "Haci Ivaz Pasa," <http://archnet.org/library/parties/oneparty.tcl?party_id $=627>$

${ }^{13}$ Iffet Orbay, Bursa (Istanbul: The Awards Ceremony Local Office, 1986) 15. <http://archnet.org/library/documents/onedocument.tcl?document_id=3704>.

${ }^{14}$ Aptullah Kuran, The Mosque in Early Ottoman Architecture (Chicago: The University of Chicago Press, 1968) 72 .
} 


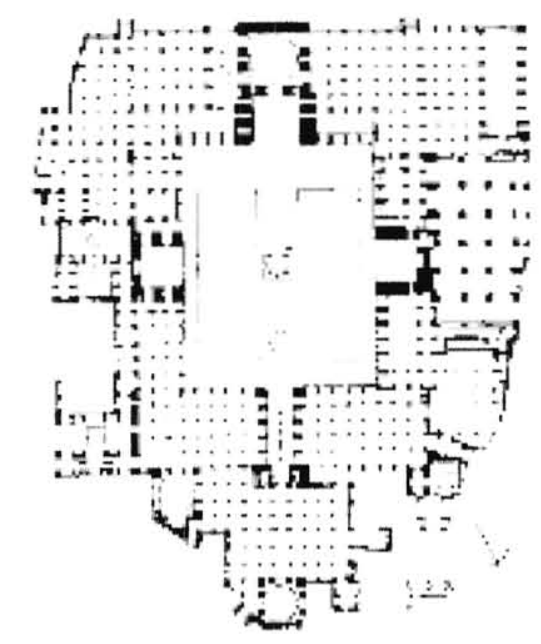

Figure 8. Great Mosque of Isfahan, Iran (8th-17th C.) Plan.

Iwans were common in the Sassanian world before Islam and rapidly became incorporated into Islamic architecture. The greatest period of diffusion was under the Selçuks in the tenth century when iwans became established as one of the basic units of Islamic architecture. One of the most typical iwan arrangements is to have four iwans opening onto a central courtyard. ${ }^{15}$

The Yesil Camii is one of the last Ottoman mosques to have such a strong connection with the Selçuk traditions. The use of iwans continued, but not in mosque architecture where the plans shifted back to mosques functioning solely as prayer halls, preceded by open-air courtyards. ${ }^{16}$

\footnotetext{
15 "Ivvan," The Dictionary of Islamic Architecture, 1996. <http://archnet.org/library/dictionary/entry.tcl?entry_id=DIA0162>.

${ }^{16}$ Kuran, "Turkish Architecture" 82.
} 
Figure 9. Yesil Camii, Bursa (1419-1421) Plan.

The plan of the Yesil Camii consists of four domed halls (iwans) which open onto a rectangular central court. The central court has a 12.5 meter diameter domed roof which once was topped with an oculus but was later filled by a lantern, and a pool at the center of its floor which collected water for the cleansing of the faithful. Both of these elements were common in iwan mosques. ${ }^{17}$ Across from the small vaulted entry hall is the elevated main iwan containing the mihrab. This domed area is smaller than the central court, with the dome covering only 11 meters in diameter. It is this space which was designated as the mosque proper and was used as the prayer hall. The transitional area from the entry hall through the central court remains secular in nature as it is considered improper to enter a mosque directly from the street. ${ }^{18}$ The side iwans are elevated only one step above the central court as opposed to the four steps leading up to the main iwan. These iwans are also domed and are flanked by

\footnotetext{
${ }_{17}$ Kuran, Mosque in Early ottoman Architecture 115.

${ }^{18}$ Godfrey Goodwin, A History of Ottoman Architecture (Baltimore: The Johns Hopkins Press, 1971) 59.
} 
two rooms each. These spaces do not serve the mosque but rather are used as meeting places and for other social functions. ${ }^{19}$ The central domed inner court can be seen as a precursor to later mosques with preceding courtyards, as it is itself adapted from a courtyard plan via the selçuk tradition. Additionally, the structure as a whole which contains various secular iwans relates to the functionality of future mosque complexes which house social, educational, political, and religious activities.

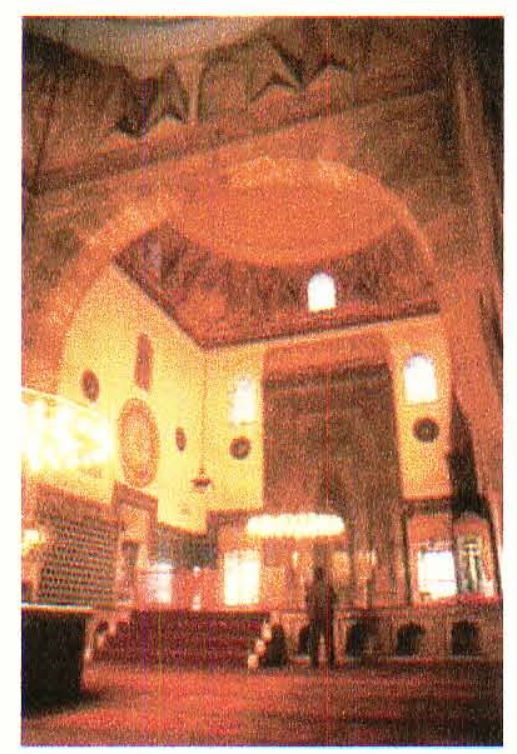

Figure 10. Yesil Camii, Bursa (1419-21) Interior view from central court towards prayer hall.

$\overline{19}$ Kuran, Mosque in Early ottoman Architecture 115. 


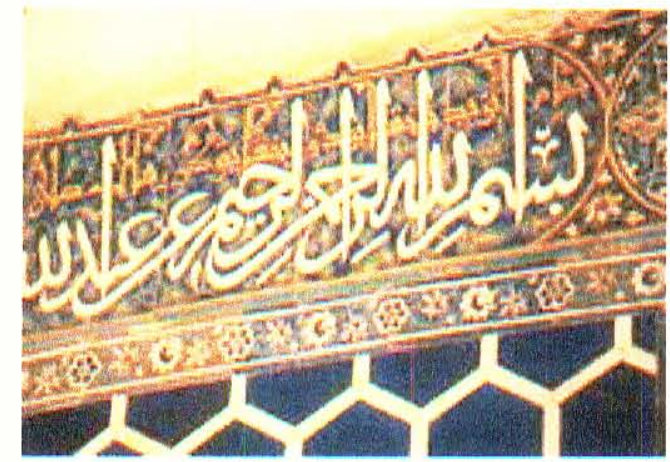

Figure 11. Yesil Camii, Bursa (1419-21) Detail of tile-work containing an inscription on the western wall of the southern iwan.

The mosque was built with stone and clad in marble. The Yesil Camii takes its name from the blue green color of the extensive decorative tile-work within it. The exteriors of the domes were once covered in these tiles as well, but are now topped with lead. ${ }^{20}$ In addition to mosaic tiling, a technique called cuerda seca was used which allows several colors to be applied to a single tile at the same time by separating them with "a greasy substance mixed with manganese" which leaves a black outline on the tiles once fired. ${ }^{21}$ The richness of the decoration is Bursa inspired but the quality of the tiling is owed, as recorded in a tiled inscription, to the Masters of Tabriz. ${ }^{22}$ The mosque remained incomplete due to the death of the sultan in 1421.

Decorative elements were continuously added up until 1424, but then the entire project was abandoned. Remaining arch

\footnotetext{
20 "Green Mosque," ArchNet <http://archnet.org/library/sites/onesite.tcl?site id=2883>.

${ }^{21}$ Blair and Bloom 142 .

${ }^{22}$ Blair and Bloom 142. The Masters of Tabriz, potters most likely from Central Asia, are renowned for creating high quality complex tilework. They are credited with elevating the craft of tilemaking in the region by bringing the cuerda seca technique to Bursa.
} 
springs are evidence that a five-bay porch had been planned but was never added. ${ }^{23}$

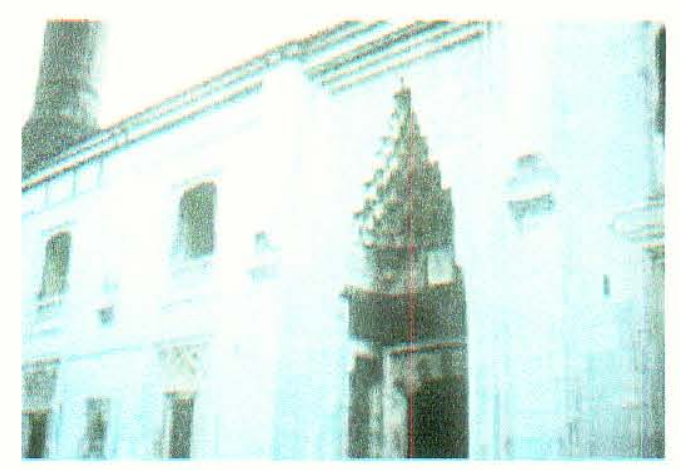

Figure 12. Yesil Camii, Bursa (1419-21) Façade showing arch springs.

Figure 13. Yesil Camii, Bursa (1419-1421) Gallery level Plan.

An innovation to the iwan mosque plan which occurred at the Yesil Camii was the addition of an upper floor to house the royal lodge. Reached by stairs at each end of the vestibule, the royal gallery was a private space used exclusively by the sultan and his wives. The balcony above the entrance hall, which overlooks the interior court and the ${ }^{23}$ Kuran, Mosque in Early ottoman Architecture 115. 
main iwan, is where the sultan would sit and listen to services. This space is divided into two distinct zones. A small domed area is connected to a raised barrel-vaulted iwan overlooking the central court. The sultan's area is flanked by spaces in which his family gathered for prayer. The rooms to either side of the royal gallery contain small fountains. When considered together, the elements of the royal gallery form a miniaturized mosque within a mosque for the benefit of the sultan's privacy. ${ }^{24}$

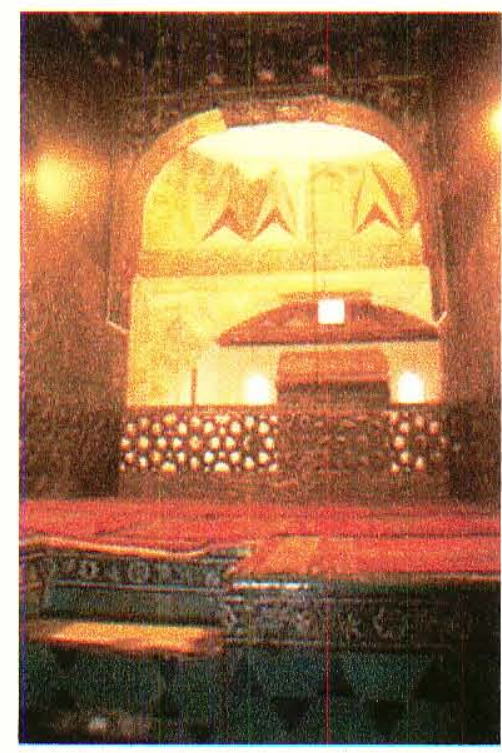

Figure 14. Yesil Camii, Bursa (1419-21) Royal gallery.

\section{Edirne}

Edirne, formerly called Adrianople (from Hadrianopolis) after the Roman emperor Hadrian, was captured in 1362 by the Turks. It became the second Ottoman capital in 1403 when Bursa was taken from the Ottomans by Timur. The Roman character of the city was preserved by both the Byzantines and the Ottomans which allowed for an expanded building

$\overline{{ }^{24}}$ Kuran, Mosque in Early Ottoman Architecture 115. 
vocabulary in the region. ${ }^{25}$ Edirne remained the primary residence of the sultans and the capital of the Empire until the capture of Constantinople in 1453. After that time, it still remained home to the extended families of the sultans, thus attracting significant building commissions throughout the Ottoman period. Edirne is located to the northwest of Istanbul, on the primary route between Asia Minor and the Balkans, which makes it a site of strategic importance. It is from here that Mehmed II planned and engaged in his attack on Constantinople in 1453. This imperial city contains some of the greatest Ottoman mosques outside of Istanbul. Sinan built one of the last examples of classical mosque architecture here, his masterpiece, the Selimiye (15691575)..$^{26}$

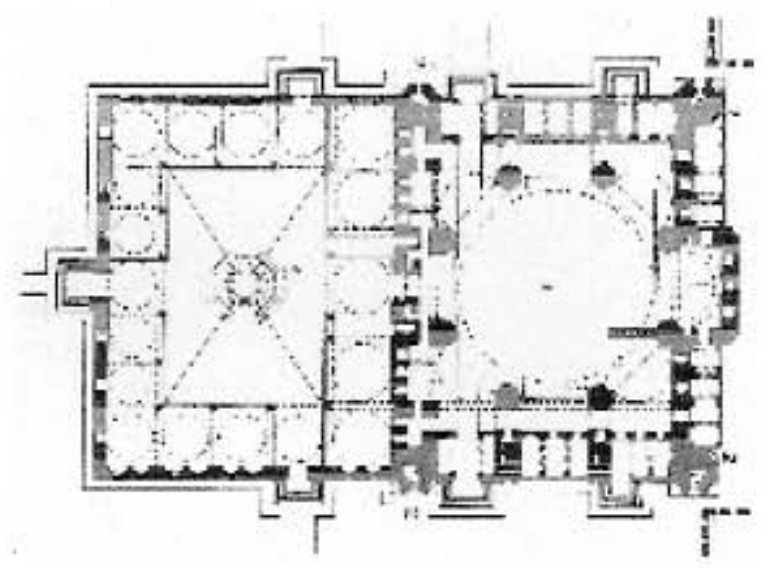

Figure 15. Selimiye Mosque, Edirne (1569-1575) Plan.

\footnotetext{
"Aptullah Kuran, "A Spatial Study of Three Ottoman Capitals: Bursa, Edirne, and Istanbul," Mugarnas Volume XIII: An Annual on the Visual culture of the Islamic World, Ed. Gillru Necipoglu (Leiden: E. J. Brill, 1996) 118. <http://archnet.org/library/documents/onedocument, $t c l$ ? document $i d=5202>$.

26 "Edirne," The Encyclopedia of Islam (Brill)

<http://www.encislam.brill.nl/data/EncIslam/co/com-0200.html>.
} 


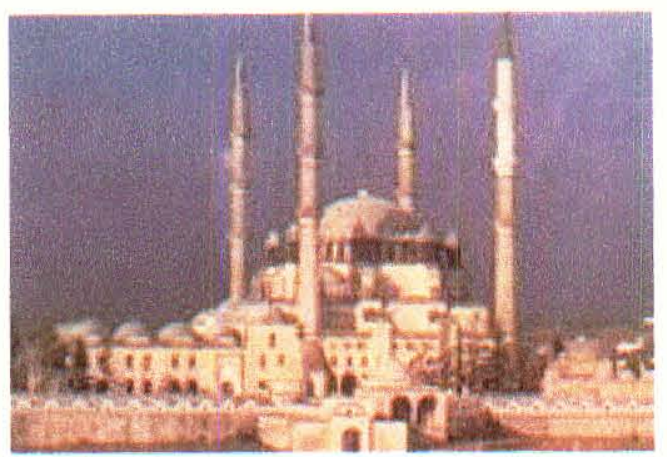

Figure 16. Selimiye Mosque, Edirne (1569-1575) Exterior.

\section{Üç Serefeli Camii}

The Üç Serefeli Camii (Three Balconied Mosque) was built of stone between 1437 and 1447 by Sultan Murad II. This mosque displays more than one example of Ottoman innovation and is widely considered the precursor to the mosques built in Istanbul.

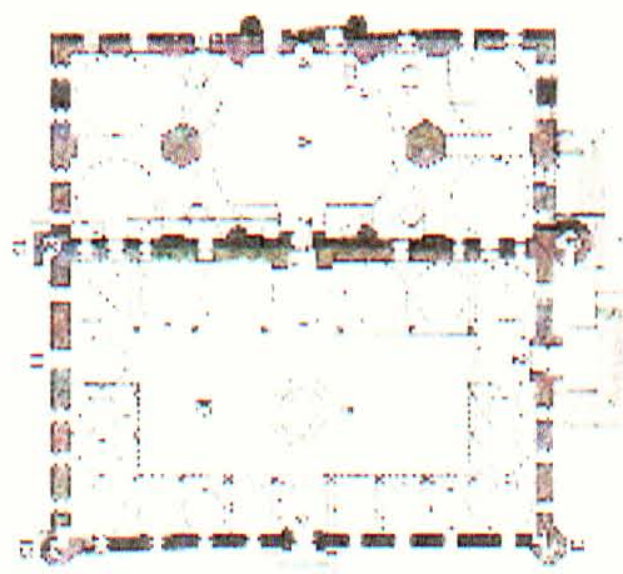

Figure 17. Üç Serefeli Camii, Edirne (1437-47) Plan.

The ÜÇ Serefeli is almost twice as large as the Yesil Camii at 66.5 by 64.5 meters. The rectangular courtyard was not symmetrically planned, which resulted in several elliptical rather than circular domes. The domes of the courtyard, as well as the four 10.5 meter diameter domes along the sides of 
the prayer hall, however, are secondary to the dominating central dome of the mosque. At 24.10 meters in diameter the central dome covers over half the space of the prayer hall. ${ }^{27}$ It is supported on exterior walls to both the north and south, and large hexagonal piers to the east and west. This expansive dome exemplifies the desire by the Ottomans to build a mosque in which the largest possible uninterrupted space is contained beneath a single massive dome. Congregations that gather for services pray communally from prayer rugs on mosque floors. Unlike Byzantine church liturgy, Islamic worship services do not involve procession or secretive rituals, so divisions of space are unnecessary. Aisles, which are separated by piers and columns, interrupt the rows of worshippers, suggest a hierarchy among the faithful, and obstruct their access to the imam leading the services. Later mosque construction, however, is as much fueled by ego as by tradition and utility in the attempt to build the biggest and the best domed mosque to rival the grand churches of Byzantium.

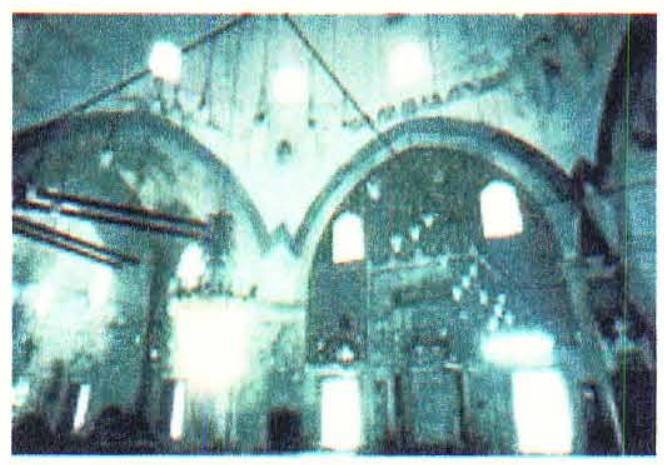

Figure 18. Üç Serefeli Camii, Edirne (1437-47) Interior view toward qibla wall.

Both here and in future Ottoman mosques, the addition of ${ }^{27}$ Blair and Bloom 144 . 
domes and semidomes are used as supports for the central dome expanding its range through a secondary support system which doesn't impede the open expanse of the floor below. Flying buttresses were also first employed here by the Ottomans to strengthen the walls and the drum supporting the central dome. ${ }^{28}$ The Üç Serefeli Camii, exclusive of the courtyard, may be described as either an eight-unit mosque, four units across and two units deep in which the four central units are united under the massive main dome, or as a five-unit mosque in which the central unit is four times as large as the remaining corner units. ${ }^{29}$

Despite its structural and aesthetic deficiencies this mosque stands as a significant turning point in Ottoman architecture, for it is in the Ü.ç Serefeli Camii that the initial experiment of the centrally planned sixteenth-century mosques was conducted. ${ }^{30}$

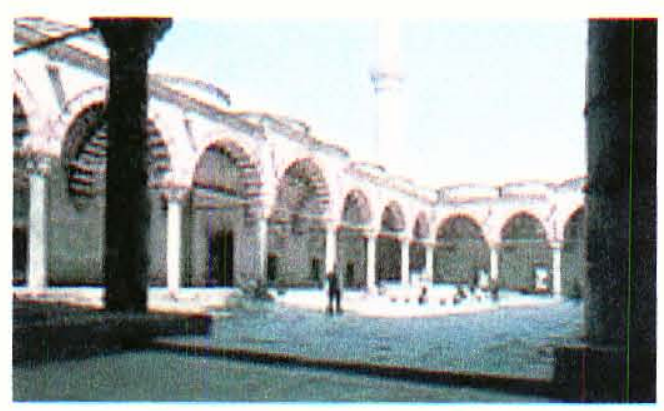

Figure 19. Üç Serefeli Camii, Edirne (1437-47) Courtyard.

The marble courtyard of the Üç Serefeli is believed to be the first one built by the Ottomans for use in a mosque. ${ }^{31}$ Columns support arches of red and white voussoirs. The façade of the mosque is fronted by a high portico containing ${ }^{28}$ Kuran, Mosque in Early ottoman Architecture 177-179.

${ }^{29}$ Kuran, Mosque in Early Ottoman Architecture 181.

${ }^{30}$ Kuran, Mosque in Early Ottoman Architecture 181.

${ }^{31}$ Argun Dündar, Edirne (Istanbul: The Award Ceremony Local office, 1983) 23. <http://archnet.org/library/documents/onedocument.tcl?document_id=3701>. 
five verde antico columns. This porch is separated from the remaining wings of the courtyard by the insertion of side gates. The main entry gate into the courtyard is on axis with the main portal of the mosque and the mihrab. ${ }^{32}$ Larger than the sanctuary, the domed and arcaded courtyard contains an ablution fountain near its center which, along with the three sided porch of the mosque, recalls the architecture of the Selçuks. ${ }^{33}$ "A later development of the courtyard abandoned the tradition of the sadirvan (ablution fountain) placed on the cross-axes of its entrances and the mihrab, which derived from the type of interior usual at Bursa. The change was begun with the open court of the Great Mosque (Ulu Camii) at Manisa and at the Üç Serefeli Camii." ${ }^{34}$

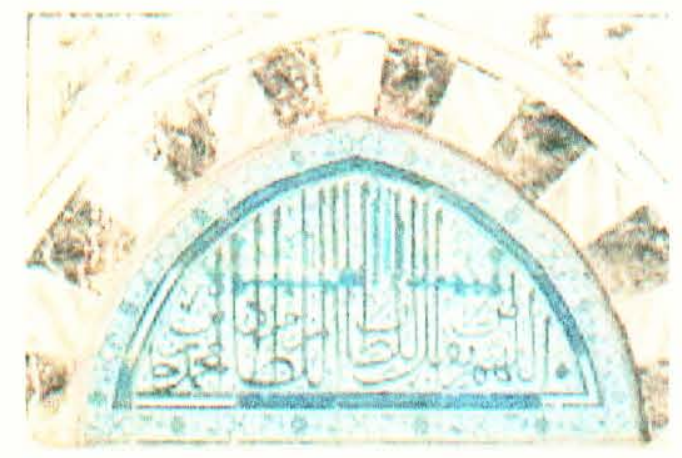

Figure 20. Üç Serefeli Camii, Edirne (1437-47) Detail of tile tympanum from portico mentioning the founder, Mehmed I.

\footnotetext{
${ }^{32}$ Goodwin, A History of Ottoman Architecture 96-98.

${ }^{33}$ Oktay Aslanapa, Turkish Art and Architecture (New York: Praeger Publishers, 1971) 203-205.

${ }^{34}$ Goodwin, A History of Ottoman Architecture 98.
} 


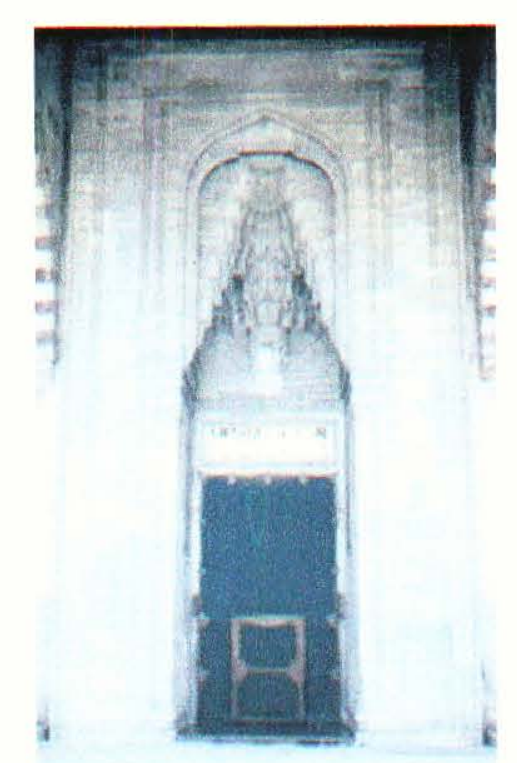

Figure 21. Üç Serefeli Camii, Edirne (1437-47) Main portal into mosque displaying muqarnas work.

"The doors are arched with interlacing polychrome marbles and carry inscriptions. The stalactites (muqarnas) above all the doors as well as the windows to the east and west of the main entry are crisply carved and set in marble frames." The tile decoration within the Üç Serefeli, like that of the Yesil Camii, is from the Masters of Tabriz workshop. Only two other commissions are thought to be attributed to this workshop in later years, one of them being the Fâtih Mosque in Istanbul built by Murad's son, Mehmed II. ${ }^{35}$

35 Blair and Bloom 145. 


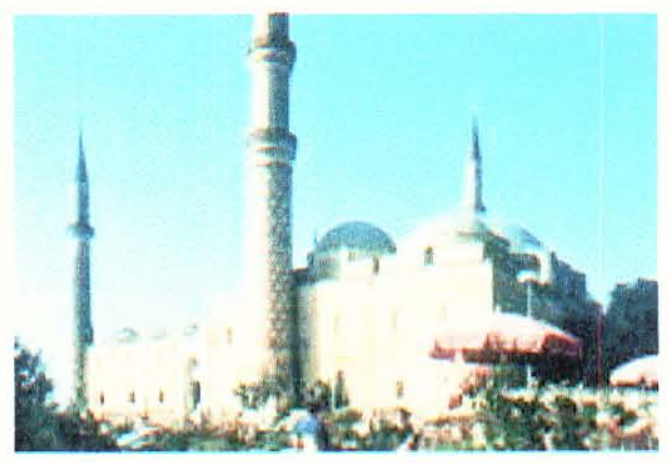

Figure 22. Üç Serefeli Camii, Edirne (1437-47) Exterior.

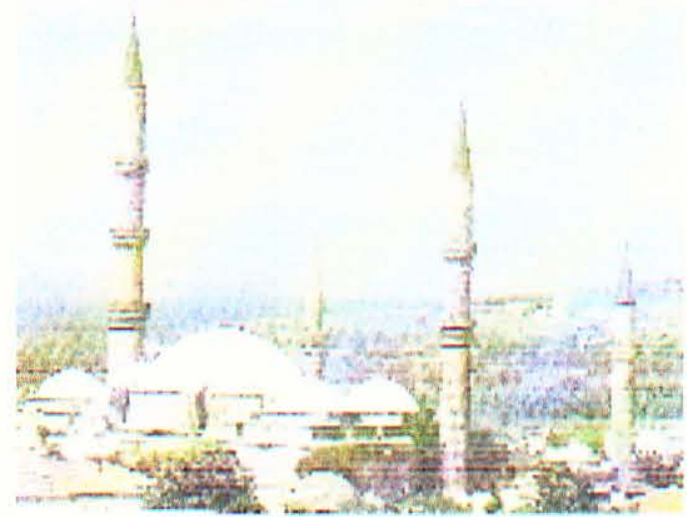

Figure 23. Üç Serefeli Camii, Edirne (1437-47) Exterior.

Four minarets surround the Üç Serefeli Camii courtyard. It is from one of these minarets that the mosque derives its name. The Üç Serefeli is the first mosque to be built with four minarets. ${ }^{36}$ For over a hundred years the southwestern minaret of the mosque remained the tallest in Ottoman architecture at over 67 meters high. It contains an unprecedented three balconies (serefe). ${ }^{37}$ The balconies of this minaret were reached by their own individual interior stairways. This is one of the earliest examples of such innovative engineering. Just like the fountain courtyard, neither are the minarets symmetrically balanced nor do they

\footnotetext{
${ }^{36}$ Aslanapa 203-205.

${ }^{37}$ Kuran, Mosque in Early Ottoman Architecture 177-181.
} 
display similar decorative styles among them. The tallest minaret is covered by a zigzag pattern while the others display spiral, fluted, and diamond shapes. The remaining three minarets are significantly shorter than the first and are of unequal heights. One of the minarets contains two balconies, while the other two minarets have only a single balcony each. ${ }^{38}$ "When there is a full team of muiezzins they mount the seven stairways to the seven serefes of the four minarets, which they divide between themselves, and make the call five times a day at the hour of prayer. This is not an accurate description of the present modest call by a lonely müezzin." ${ }^{39}$

\section{Chapter Summary}

Early mosque construction in Turkey was characterized by the adaptation of regional elements in the creation of a new standard for mosque architecture. Some themes and elements adopted early on continued into the sixteenth century. These include the emphasis on centrality as evidenced by the centrally located courtyard of the Yesil Camii, the use of the multi-bay Turkish porch and the uninterrupted expanses of floor space in the prayer halls. The large central dome of the ÜÇ Serefeli which, when combined with the large forecourt, also a new standard in mosque architecture, instilled a sense of monumentality. The importance of the central axis and the multifunctional aspects of a mosque as derived from the Yesil Camii, in combination with the required elements inherited from the Mosque of the Prophet including the minbar, mihrab, minaret, and ablution fountain, ${ }^{38}$ "Uc Serefeli Mosque," ArchNet <http://archnet.org/library/sites/onesite.tcl?site_id=2910>.

${ }^{39}$ Goodwin, A History of Ottoman Architecture 99. 
would all be elements important to mosque construction in the sixteenth century as well. The culmination of this early period of mosque architecture was the construction of the Üç Serefeli Camii which demonstrated the combination of a variety of architectural elements into a single cohesive presentation. Though it lacks the simple beauty and grace of the later mosques, the Üç Serefeli is the crowning achievement of early Ottoman mosque architecture. 
CHAPTER III

BYZANTINE CHURCH CONSTRUCTION

\section{Constantinople}

Constantinople, the capital of the Byzantine Empire, was founded in 330 at the confluence of Europe and Asia. The Golden Horn passes from the heart of the city into the Bosphorus, the straight that connects the Sea of Marmara to the Black Sea and divides the city between the two continents. Surrounded by water, Constantinople's strategic location made it desirable to many and therefore prone to attack. The Byzantines successfully defended Constantinople from Muslim invaders until 1453. The city finally fell to Ottoman Sultan Mehmed II, due in no small part to its weakened state as a result of the brief but brutal occupation by the Latins of the Fourth Crusade (1204-1261).

The location of Constantinople, at the junction of two continents and three major bodies of water, was critical in its development as the capital of successive empires. The terrain within the city was just as important to its growth as the topography of the region around it. Location was integral to the siting of the city's most important monuments. Six of the seven hills around which the major churches, and eventually the mosques, of the city were built extend from the tip of the peninsula along the Golden Horn. It is along this axis that the architectural wonders of the city were erected. 
Constantinople wasn't the only source for Byzantine architecture in the region. The Ottomans had access to Byzantine building methods for many years prior to the conquest of Constantinople. The Byzantine Empire had spread throughout the region in much the same way the Ottoman Empire would.

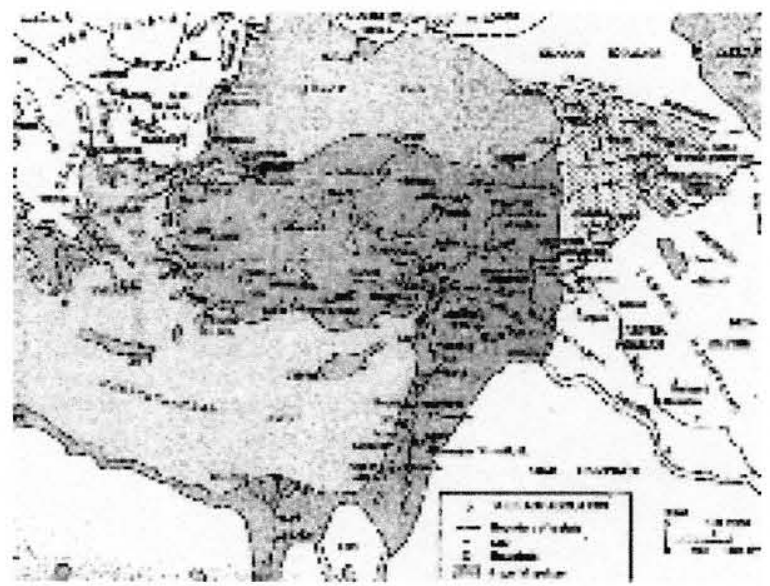

Figure 24. Map of Byzantine Empire (633).

At its height, the Byzantine Empire reached as far as the Near East and encompassed much of what would become Muslim territory. As late as 1282 , the future Ottoman capital cities of Bursa, Edirne, and Constantinople were under the control of the Byzantine Empire.

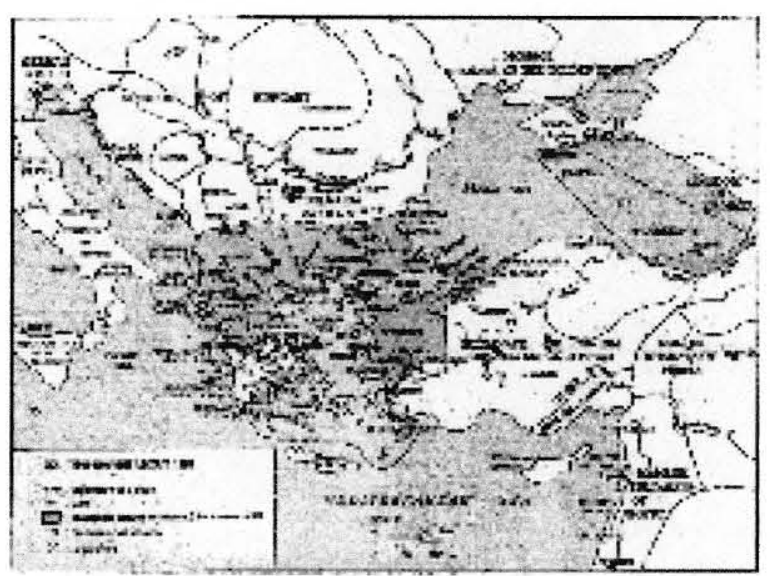

Figure 25. Map of Byzantine Empire (1282). 
Additionally, trade had long exposed the tribes of Asia to the cultural resources of the Byzantines. It stands to reason, however, that as the imperial jewel of the Byzantine empire, Constantinople's influence weighed most heavily on the imperial architecture of the Ottomans within that city.

\section{SS Sergius and Bacchus}

The Byzantine church of SS Sergius and Bacchus is believed to have been built beginning around 527 and was completed by 536 at the beginning of Emperor Justinian's reign. Ss Sergius and Bacchus is frequently referred to as Little Hagia Sophia because of its similar profile to the later church. SS Sergius and Bacchus is considered by some to be a precursor to the Church of Hagia Sophia, while others view it more as a contemporary. SS sergius and Bacchus and Hagia Sophia were both completed during the same time frame. The church of Hagia Sophia was completed in five years, an incredibly short period of time considering its grand scale. For this reason, detailed planning for the building of Hagia Sophia must have taken place well before construction commenced. Due to the relative time frames for the construction of both churches, it is unreasonable to assume that SS Sergius and Bacchus could have been the influence for the design of Hagia Sophia; rather, the two churches are contemporaries. ${ }^{40}$

The Church of SS Sergius and Bacchus was built in conjunction with the Church of SS Peter and Paul. The two churches were erected adjacent to one another and shared a

\footnotetext{
40 Rowland J. Mainstone, Hagia Sophia: Architecture, Structure, and Iiturgy of Justinian's Great Church (New York: Thames and Hudson, 1988 ) 154-157.
} 
narthex, atrium, and propylaeum but, while they occupied the same site, they differed in style. Saints sergius and Bacchus were honored with an octagonal centrally planned church. Peter and Paul, on the other hand, were acknowledged with a church in the basilica style. ${ }^{41}$

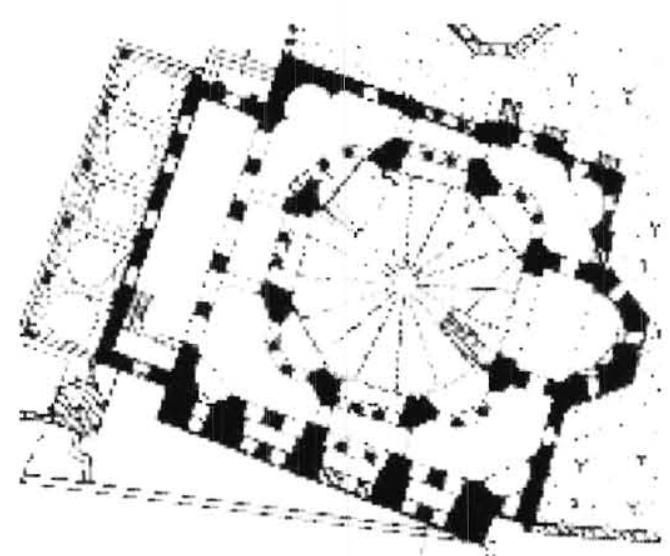

Figure 26. SS Sergius and Bacchus, Constantinople (c.527-36) Plan.

The Church of SS Sergius and Bacchus is irregularly shaped as a result of its placement between two existing structures, the Palace of Hormisdas and the Church of SS Peter and Paul. The available plot of land lent itself to the construction of a square church. Unlike the exterior shape, the interior plan is of an irregularly placed octagon surrounded by an octagonal ambulatory. Strangely, "no attempt was made to counteract the irregularity of the site, and even the seemingly regular octagon of the piers has sides of different length." ${ }^{42}$ A two-storied narthex was built

\footnotetext{
$\overline{41}$ "Sergius," Ecumenical Patriarchate of Constantinople Website $<$ http://www.patriarchate.org/ecumenical_patriarchate/chapter_4/html/ser gius_and bacchus.html>

${ }_{42}$ Richard Krautheimer, Early Christian and Byzantine Architecture (New York: Viking Penguin, 1986) 222-225.
} 
along the west end of the church and a single apse was constructed at the east end. ${ }^{43}$

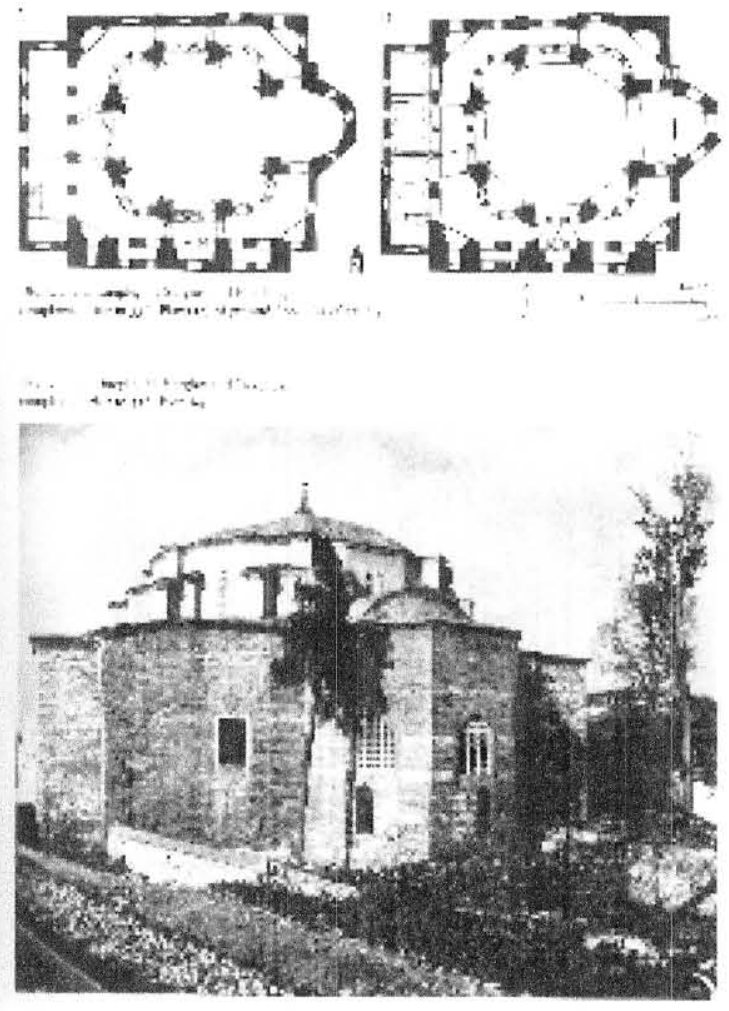

Figure 27. SS Sergius and Bacchus, Constantinople (c.527-36) Plans and exterior.

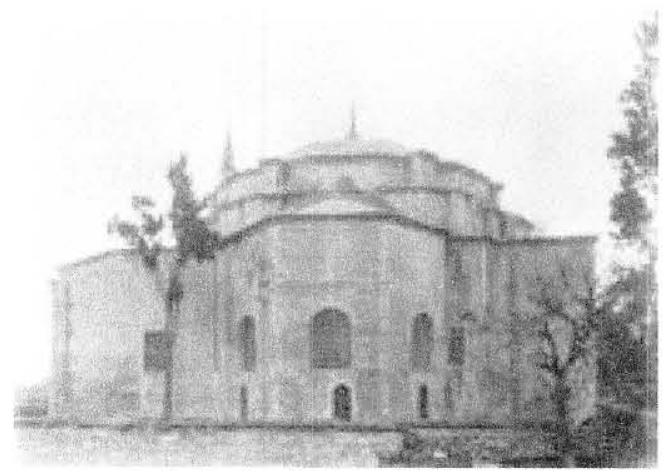

Figure 28. SS Sergius and Bacchus, Constantinople (c.527-36) Exterior.

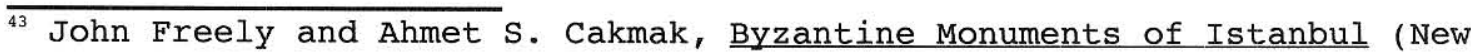
York: Cambridge University Press, 2004) 130-132.
} 
SS Sergius and Bacchus was "constructed of a uniform brick masonry with courses of stone occurring occasionally at intervals of about twenty courses. This is a Justinianic type of masonry also observable at Hagia Sophia." ${ }^{44}$ Topping the structure is a "pumpkin" shaped 50 foot diameter dome. Sixteen divisions of alternating flat and concave sections give the dome its "oddly undulatory or corrugated effect." Each of the eight flat sections is pierced by a window. ${ }^{46}$

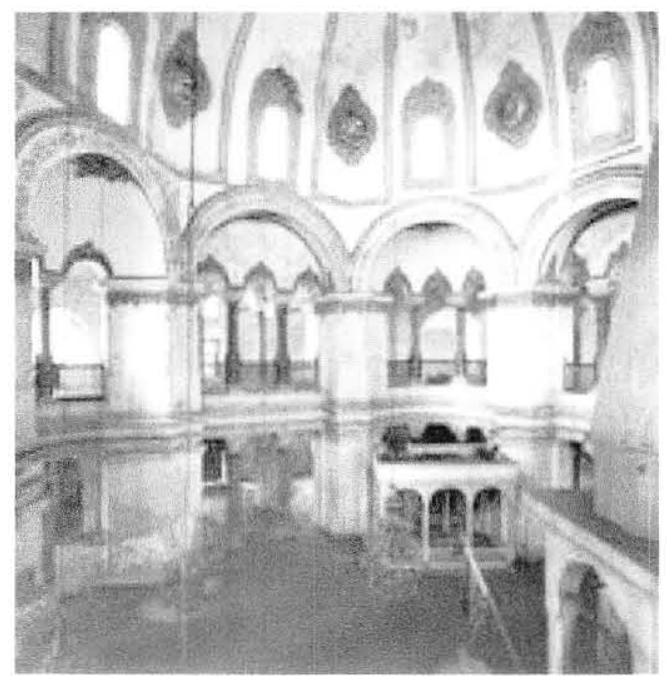

Figure 29. SS Sergius and Bacchus, Constantinople (c.527-36) Interior.

The dome sits on eight arches supported on eight polygonal piers. Between each of the piers, exclusive of the pair flanking the sanctuary apse, are pairs of marble columns. These piers and columns define the inner octagon of the ground floor, around which the ambulatory and the Ushaped gallery above are formed. The four exedrae of the

\footnotetext{
${ }^{44}$ Thomas Mathews, The Early Churches of Constantinople: Architecture and Liturgy (University Park: The Pennsylvania State University Press, 1971) 44-45.

${ }^{45}$ Freely and Cakmak, Byzantine Monuments of Istanbul 130-132.

${ }^{46}$ Freely and Cakmak, Byzantine Monuments of Istanbul 130-132.
} 
inner octagon, defined only by pairs of columns, extend into the surrounding ambulatory blurring the divisions of the inner and outer octagonal space. ${ }^{47}$ The columns on both levels alternate between verde antico and red granite. ${ }^{48}$ At the four corners of the square nave are semicircular niches which are also fronted by columns. These exedrae create the outer octagon of the ambulatory and are topped by semidomes at the gallery level.49 "In the original plan access to the gallery may have been restricted in order to give it the character of a private Imperial oratory. ${ }^{50}$

The similarities between SS Sergius and Bacchus and Hagia Sophia may not be immediately clear, considering that the first is a centrally planned double-shell octagonal church and the latter is a basilica.

Hagia Sophia contains all the elements of a doubleshell octagon: the domed core, the billowing niches, the enveloping aisles and galleries. But these components have been, as it were, broken up and rearranged lengthwise - for the simple reason that the size required for Justinian's Great Church made radial expansion of an octagonal plan impracticable. The octagon of sergius and Bacchus and the plan of the Hagia Sophia belong to the same family. ${ }^{51}$

\section{Hagia Sophia}

Hagia Sophia is quite possibly the most studied Byzantine church. An architectural marvel that has withstood nearly 1,500 years of civilization and two rival empires, this church is the building most frequently credited with

\footnotetext{
${ }^{47}$ Krautheimer 222-225.

${ }^{48}$ Freely and Cakmak, Byzantine Monuments of Istanbul 130-132.

49 "Kucuk Ayasofya Mosque," Archnet

<http://archnet.org/library/sites/one-site.tcl?site_id=7343>

${ }^{50}$ Thomas Mathews, the Early Churches of Constantinople: Architecture and Liturgy 51 .

${ }^{51}$ Krautheimer 222 .
} 
influencing the future of Ottoman architecture within the city. The second church to bear the name of Hagia Sophia, and the third church to stand on the site within 200 years, Justinian's Hagia Sophia still stands today remarkably intact and true to its original Byzantine plan. ${ }^{52}$ When the Nika Riots (532) destroyed the original Hagia Sophia, Justinian vowed to build an even more impressive church on the same site. In 532 construction began on the new Hagia Sophia under the direction of Anthemius of Tralles and Isidorus of Miletus, a mathematician and a physicist charged with the design of the new church. ${ }^{53}$ Hagia Sophia commands an impressive view from the tip of the peninsula. Built upon the First Hill of Constantinople, it overlooks the Golden Horn, the Bosphorus, and the Sea of Marmara.

"As the Cathedral of the Ecumenical Patriarchate of Constantinople for over a thousand years, the Hagia Sophia was the center of Eastern Christianity from 360 to the Ottoman conversion." ${ }^{54}$ After the Ottoman conquest, it would spend more than 400 years as a center for Islamic worship. The architecture of Hagia Sophia managed to span vast distances of both time and space, while sheltering the faithful of two competing religions.

\footnotetext{
52 "Hagia Sophia," Archnet <http://archnet.org/library/sites/onesite.tcl?site_id=2966>

${ }^{53}$ Thomas Mathews, Byzantine Churches of Istanbul: A Photographic Survey (University Park: The Pennsylvania State University Press, 1976) 263.

54 "Hagia Sophia," Archnet <http://archnet.org/library/sites/onesite.tcl?site_id=2966>
} 


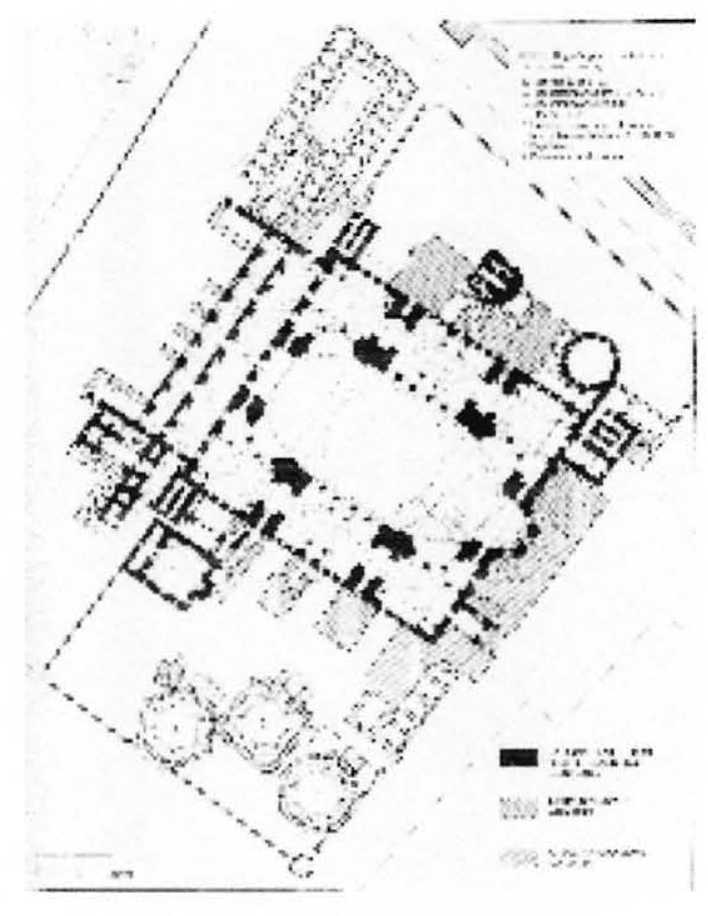

Figure 30. Hagia Sophia, Constantinople (532-37) Plan.

The plan of Hagia Sophia can be characterized as neither strictly centralized nor basilican in nature. Rather, it is a combination of the two styles, a centralized basilica. ${ }^{55}$

There are at least two views on the origins of the plan of Hagia Sophia. Sources are divided on whether the design is derived from eastern or western sources. The design may have been the result of the influence of centrally planned martyria in the East, or the tradition of domed Roman structures in the west such as the Pantheon in Rome. ${ }^{56}$ An eastern origin of the plan of Hagia Sophia would give even greater credence to the claim of the Ottomans that their

\footnotetext{
Mainstone 159-161.

${ }^{56}$ Krautheimer 225-226.
} 
capture of Constantinople and the appropriation of Hagia Sophia for Islam was their destiny. ${ }^{57}$

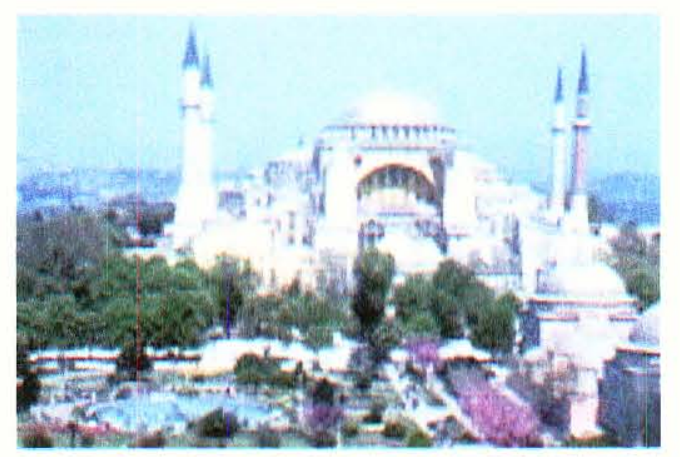

Figure 31. Hagia Sophia, Constantinople (532-37) Exterior.

Hagia Sophia is a domed basilica which uses two semidomes to counter the thrust of the great central dome which is supported on pendentives and four massive piers. "The four great piers that support the dome of the nave are concealed within the surrounding galleries and aisles." ${ }^{58}$ The suspension of a dome on four arches and pendentives was not uncommon in the ancient world. The approach taken at Hagia Sophia, however, of adding two semidomes of equal radius to the main dome was quite uncommon. ${ }^{59}$ By opening up the semidomes and forming merging pendentives, the move was made toward topping a square with a dome eliminating the added difficulty of constructing an intervening octagonal drum. ${ }^{60}$

Like the domes of the mosques to follow, the dome of Hagia Sophia fell several times and had to be replaced. The ${ }^{57}$ Gülru Necipoglu, "The Life of an Imperial Monument: Hagia Sophia after Byzantium," Hagia Sophia, eds. R. Mark and A. Cakmak (New York: Cambridge University Press, 1992) 198-202.

${ }^{58}$ Mathews, Early Churches of Constantinople 95-96.

${ }^{59} \mathrm{M}$. Ahunbay and $\mathrm{z}$. Ahunbay, "Structural Influence of Hagia Sophia on Ottoman Mosque Architecture," Hagia Sophia, Eds. R. Mark and A. Cakmak (New York: Cambridge University Press, 1992) 180.

${ }^{60}$ Mainstone 163 . 
first collapse was total, for the impossibly vast expanse beneath the dome had indeed been impossible at the time of its construction. Barely twenty years after its completion, the massive central dome of Hagia Sophia proved it was as delicate as it had appeared to be, by succumbing to faulty engineering the result of insufficient lateral support for the domical superstructure. Reconstruction of the dome took five years, a duration equal to the period of time it took to erect the entire structure. This time, however, the dome was built by Isidoros the Younger with a higher profile intended to reduce thrust and thereby increase stability. ${ }^{61}$

Additionally, heavy buttresses were added to help counter the thrust of the dome. The base span of the dome ranges from 32.2 meters to 32.7 meters across. ${ }^{62}$ Centrally placed 56 meters above the nave, the approximate 32 meter diameter span of the dome was unrivaled by any other building from antiquity through the Middle Ages. ${ }^{63}$

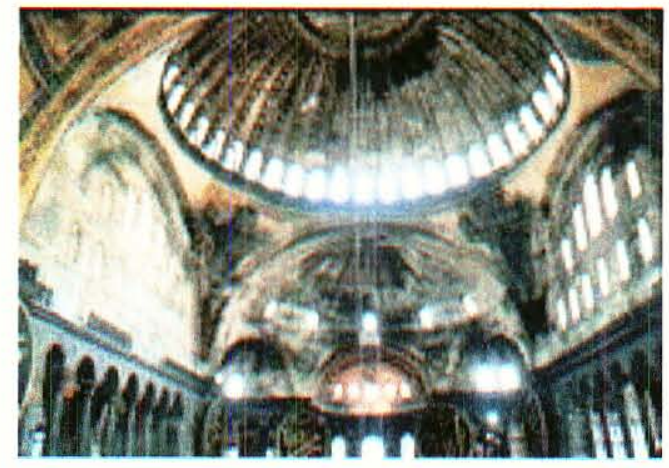

Figure 32. Hagia Sophia, Constantinople (532-37) Apse semidome and central dome.

\footnotetext{
"Hagia Sophia," Grove Dictionary of Art online

${ }^{62}$ "Hagia Sophia," Archnet <http://archnet.org/library/sites/onesite.tcl?site_id=2966>

${ }^{63}$ Mathews, Byzantine Churches of Istanbul: A Photographic Survey 263.
} 


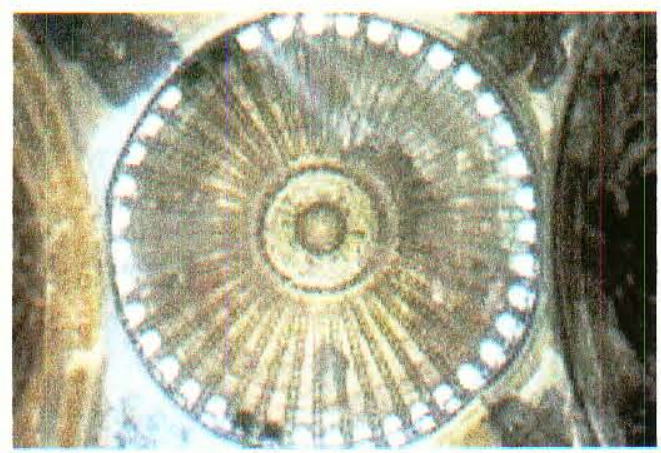

Figure 33. Hagia Sophia, Constantinople (532-37) Interior central dome.

Forty windows separate forty ribs and emphasize the gravity-defying appearance of the dome. The dome is supported on pendentives and four massive piers which, in conjunction with arcades, separate the nave from the aisles. Large semidomes set atop single arches abut the central dome along the central axis to the northwest and southeast and distribute the weight of the dome. The load, however, is unevenly countered by double arches and pier buttresses to the northeast and southwest. ${ }^{64}$ Twenty years after the construction, Procopius recorded the difficulties that plagued construction of Hagia Sophia. In his book, St. Sophia at Constantinople, Eugene Kleinbauer provides an interpretation of that testimony.

The main piers began to tilt outward while the great eastern arch was going up; today the inclination of the piers from vertical is almost 61 $\mathrm{cm}$. Slow-hardening mortar was one of the causes of these tilts and deformations. Inadequate foundations for the main piers and buttressing were others. Concomitantly, the great north and south arches exerted enough pressure on the subadjacent tympanums that some columns began to shed flakes. The original dome may have been planned as a perfect circle, but it was actually constructed as an ellipse about $1.98 \mathrm{~m}$. wider from north to south

\footnotetext{
64 "Hagia Sophia," Archnet <http://archnet.org/library/sites/onesite.tcl?site_id=2966>
} 
than from east to west because of the outward settlement of the main and buttress piers. These and other deformations continued until the collapse of the first dome, and even after the dome was rebuilt by Isidore the Younger. ${ }^{65}$

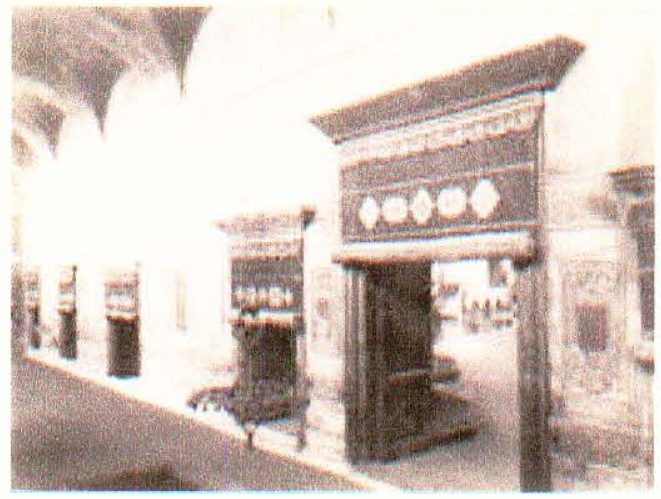

Figure 34. Hagia Sophia, Constantinople (532-37) Interior inner narthex and the Imperial door.

Two nartheces precede entry into the nave of the church from the northwest. Each narthex contains nine vaulted bays, though the inner narthex is both wider and taller than the outer narthex and contains a second level which connects to the galleries within the church. The inner narthex contains nine doors which lead into the nave. The centermost door is the Imperial door and is larger than the rest.

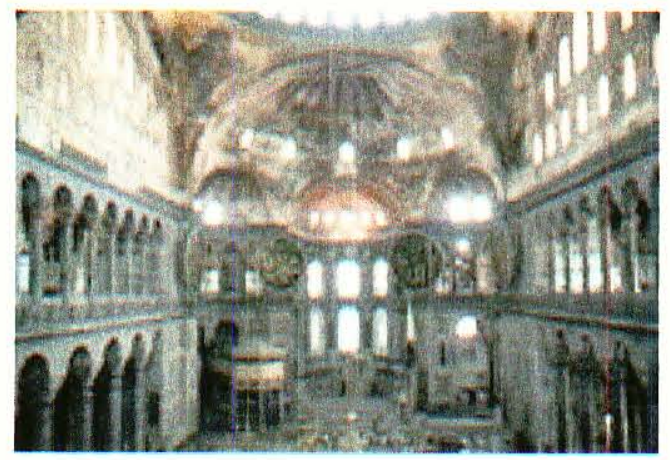

Figure 35. Hagia Sophia, Constantinople (532-37) Interior view of nave toward the apse.

\footnotetext{
65 W. Eugene Kleinbauer, Saint Sophia at Constantinople (Dublin, New Hampshire: William L. Bauhan, Publisher, 1999) 62-63.
} 
The nave of Hagia Sophia is about twice as long as it is wide and is flanked by aisles. This space would become an important focus of later Ottoman architects, as they sought to free up the interior of mosques even further. The area of the floor is 73.5 by 69.5 meters total. Four exedrae and a sanctuary apse all topped by semidomes defy the rectangular shape of the church interior. Marble panels and columns "gathered from pagan temples of Western Anatolia" line the nave. ${ }^{66}$

Hagia Sophia was originally built with an atrium which was still visible during the sixteenth century.

Gyllius described an area west of Hagia Sophia with a fountain in the middle located several steps lower. The plan called for twelve piers disposed along three sides of an open court, with a pair of columns between each pair of piers. This alternating arcade enclosed a rectangular area, wider than it was long, measuring 47.7 by 32.3 meters. ${ }^{67}$

This atrium is no longer in existence, but the presence of such a forecourt would have been acceptable to the ottomans as it was in line with the plans of Ottoman mosques which contained preceding fountain courtyards. ${ }^{68}$

\section{Constantine Lips}

The Monastery of Constantine Lips contains two Byzantine churches built side by side several hundred years apart. The first, the Theotokos Panachrantos, was founded in 908 to the north of the site by Constantine Lips, a high ranking official, under the rule of Leo VI the wise. Immediately

\footnotetext{
66 "Hagia Sophia," Archnet <http://archnet.org/library/sites/onesite.tcl?site_id=2966>

${ }^{67}$ Mathews, Early Churches of Constantinople 88-89.

${ }^{68}$ Mathews, Early Churches of Constantinople 88-89.
} 
south of it, built in the late 13 th century by Empress Theodora, wife of Michael VIII Palaeologus, is the Church of St. John the Baptist. ${ }^{69}$ The Church of Constantine Lips was a cross in square plan, the most commonly used plan for Byzantine church architecture from the ninth century onward. The south Church of St. John the Baptist, on the other hand, was built as an ambulatory plan. ${ }^{70}$ "That is its nave was divided from the aisles by a triple arcade to the north, west, and south, with each arcade separated by two columns." ${ }^{71}$

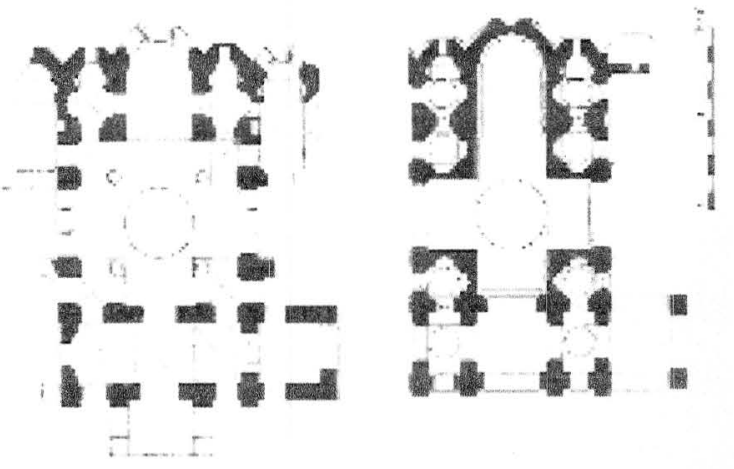

Figure 36. North Church of Constantine Lips, Constantinople (908) Ground floor and gallery plans.

Initially five apses completed the eastern end of the church of Constantine Lips. It was unusual to have more than three apses, but a fourth belonged to a now demolished northern chapel, and a fifth apse to the south was eventually absorbed into the Church of St. John the Baptist. The Church of Constantine Lips was preceded by a porch and a doublestory narthex which connects to interior galleries containing four domed chapels, one atop each corner of the nave. These 69 "Constantine Lips," Ecumenical Patriarchate of Constantinople website $<$ http://www.patriarchate.org/ecumenical_patriarchate/chapter_4/html/con stantine_lips.html>

${ }^{70}$ Freely and Cakmak, Byzantine Monuments of Istanbul 166-176.

${ }^{71}$ Freely and Cakmak, Byzantine Monuments of Istanbul 176. 
smaller domes surround but do not adjoin the central dome of the church. ${ }^{72}$

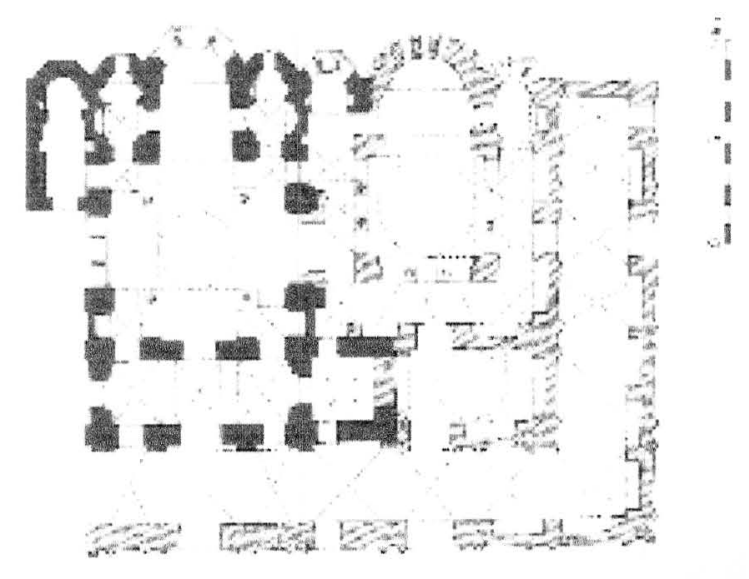

Figure 37. Churches of Constantine Lips (908-13th century) Plan.

The South church is also topped by a dome which is supported on four piers. Pairs of columns placed between the piers and amid triple arcades divide the naos from the aisles, create the ambulatory on all sides except the triapsidal eastern end, and support a vaulted lower roof. The South church was designed as a funerary chapel and the southernmost apse is designated as such. ${ }^{73}$ The narthex of the Church of St. John the Baptist is irregular because of its association with the North church. The stair tower of the North church interrupts the symmetry so that only the southern bay of the narthex is domed. ${ }^{74}$

Much of the decoration of the North Church has been preserved, including sculptured decoration in cornices and

\footnotetext{
72 Freely and Cakmak, Byzantine Monuments of Istanbul 176.

73 "Constantine Lips," Ecumenical Patriarchate of Constantinople Website <http://www,patriarchate.org/ecumenical_patriarchate/chapter_4/html/con stantine_lips.html>

${ }^{74}$ Freely and Cakmak, Byzantine Monuments of Istanbul 176-177.
} 
window frames. ${ }^{75}$ The eastern side of the church still displays rich architectural decoration including alternating tripartite arched windows, blind niches, and elaborate brickwork following the Byzantine tradition of interspersing courses of brick with stone in order to visually lighten the structure. ${ }^{76}$

\section{Theotokos Pammakaristos}

The original construction of the Theotokos Pammakaristos was completed during the 12th century under the reign of Alexius Comnenus on a ridge between the Fifth and Sixth Hills of Constantinople.

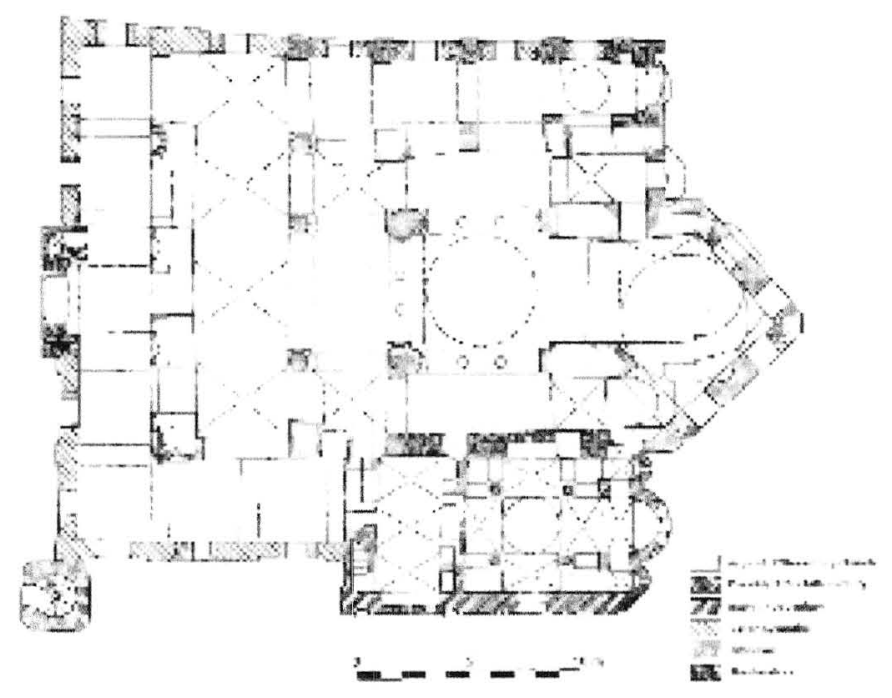

Figure 38. Theotokos Pammakaristos, Constantinople (12th century) Plan.

The Theotokos Pammakaristos, an ambulatory plan church like the later Church of St. John the Baptist, was divided to

\footnotetext{
75 Freely and Cakmak, Byzantine Monuments of Istanbul 177.

76 "Pammakaristos," Ecumenical Patriarchate of Constantinople Website <http://www.patriarchate.org/ecumenical_patriarchate/chapter_4/html/pam makaristos.html>
} 
the north, west, and south by triple arcades which separated the naos from the barrel and groin vaulted ambulatory. Three apses to the east and a single narthex to the west complete the floor plan. The central dome, which is divided into 24 sections and is pierced by twelve windows, sits atop a high drum. ${ }^{77}$

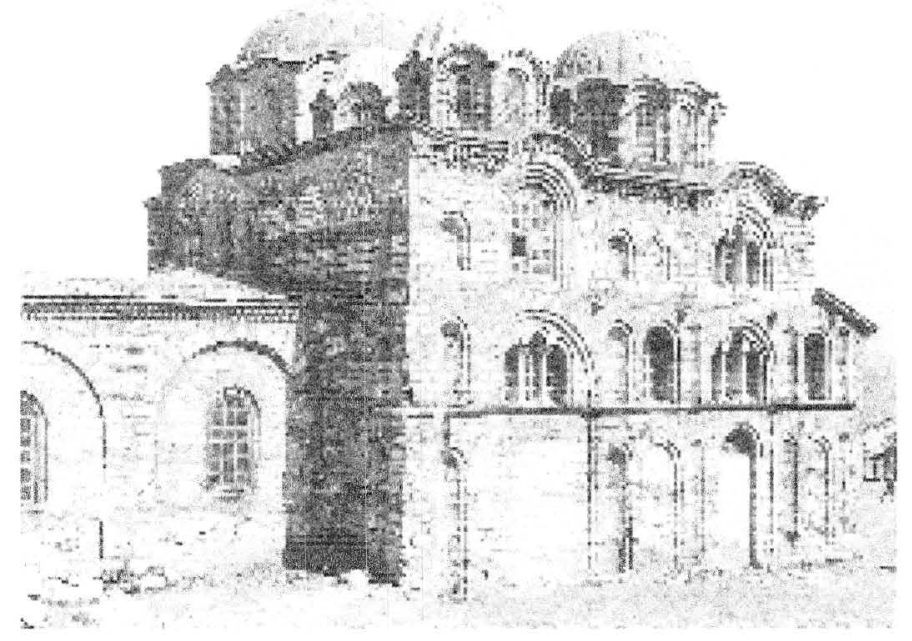

Figure 39. Theotokos Pammakaristos, Constantinople (12th century) Exterior facing parekklesion.

An outer narthex which was added to the church in the 15th century comprised five vaulted bays to the west side of the church and two more to the south. ${ }^{78}$

The exterior view of the building is defined strongly by the heights of different spaces. The vaulted spaces of the ambulatory spaces are covered with a single low-lying flat roof, from which the tall walls of the nave emerge with their clerestory windows topped by a single dome, and the slightly lower walls of the adjacent parekklesion nave. The outer aisle to the north also has a small dome at its eastern end. ${ }^{79}$

\footnotetext{
${ }_{77}$ Freely and Cakmak, Byzantine Monuments of Istanbul 264-268.

${ }^{78}$ Freely and Cakmak, Byzantine Monuments of Istanbul 264-268.

79 "Fethiye Mosque," Archnet <http://archnet.org/library/sites/onesite.tcl?site_id=7171>
} 
The church was rebuilt by Michael Ducas Glabas Tarchaniotes near the end of the 13th century, when a portico and domed chapel were added to the north of the existing church. ${ }^{80}$ The most important changes were made around 1310 when Michael's wife, Maria Ducaina Comnena Palaeologina Blachena, added a funerary chapel for her husband to the south side of the church.

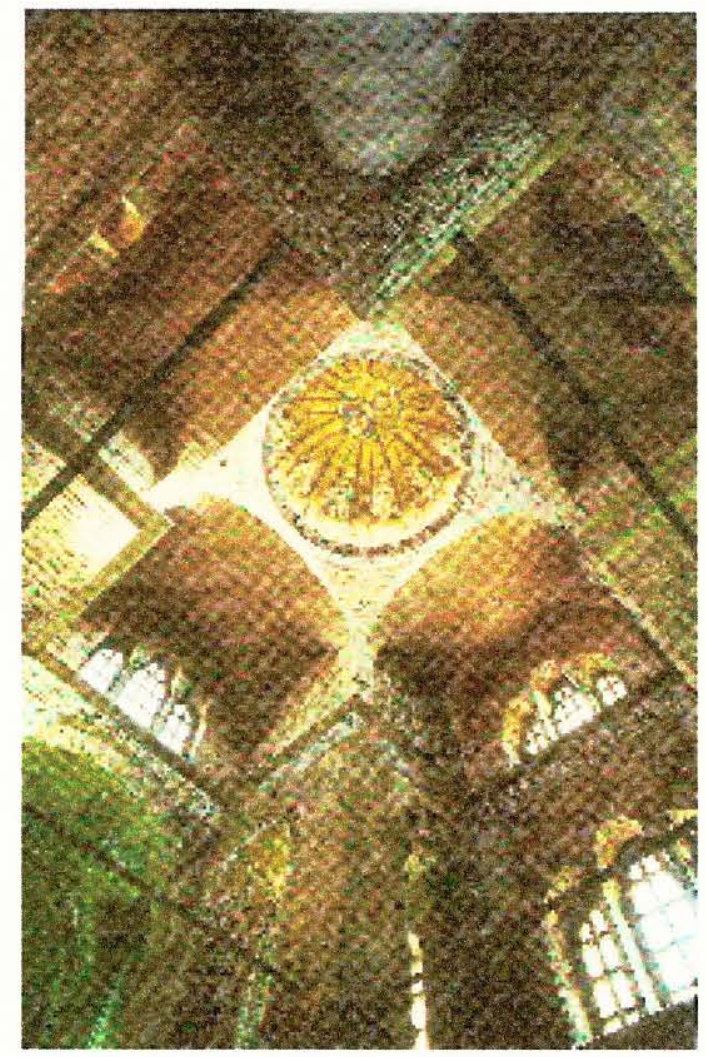

Figure 40. Theotokos Pammakaristos, Constantinople (12th century) Interior of parekklesion.

This parekklesion was based on the design of a small crossin-square church. Four columns support a dome carried on a dodecagonal drum. Twelve ribs divide the dome which is pierced by windows. The chapel has its own narthex with a

$\overline{{ }^{80}}$ "St. Mary Pammakaristos," Grove Dictionary of Art Online 
second floor gallery topped by two domes. ${ }^{81}$ The brick and stone parekklesion is one of the finest examples of Palaeologan renaissance architecture. Unlike the main church of the Theotokos, the parekklesion has survived virtually intact, including the magnificent dome mosaic of Christ and the twelve apostles.

The façades are lavishly decorated with arcades, niches, brick patterning and inscriptions. The domes are scalloped on the exterior and ribbed or fluted on the interior. Marble revetment, of which some fragments have survived, covered the interior walls, topped by a champlevé relief frieze. ${ }^{82}$

\section{Chapter Summary}

The Byzantine churches discussed in this chapter were all preserved by the Ottomans for use as mosques. What they all have in common with each other, as well as the newly recognized Ottoman imperial mosque plan, is an adherence to centralized planning, domed roofs containing large central domes, and in most cases, a porch. The designs of the churches included the popular cross-in-square plan and a centralized octagonal plan with ambulatory. Hagia Sophia combined two plans into a centralized basilica in which the focus is on the central axis. The galleries of the churches were comparable to the royal lodges evident in early Ottoman mosques. The Byzantine decorative program, which included tile mosaics, was similar to the one employed by the Ottomans, with the exception of figural elements. Each of these churches would be adopted by the Ottomans as a mosque, with relatively minor alterations, meaning they already had a plan which coincided with the best perceived layout for a

\footnotetext{
${ }^{81}$ Freely and Cakmak, Byzantine Monuments of Istanbul 264-268.
}

82 "St. Mary Pammakaristos," Grove Dictionary of Art online 
mosque. They were all reconsecrated as mosques before the end of the sixteenth century, so their plans could have influenced the construction of new mosques within the city. Yet, while the Ottomans had access to Byzantine structures long before they conquered Constantinople, they did not manage to build any mosques similar to the churches even though domes had long been a part of mosque construction. 
CHAPTER IV

WHEN THE WEST MOVED EAST

\section{Early Years of Sultan Mehmed II}

Sultan Mehmed II Fâtih (the Conqueror) was responsible for opening trade relations between the Ottomans in Istanbul and the West. This relationship was influential in the development of a cultural exchange in which European artists were admitted into the exotic and mysterious realm of ottoman Turkey by personal invitation of the imperial court in order to teach, and perhaps learn a little something in return. Mehmed II had a knowledge of the best Renaissance artists of his time and frequently called on them to serve him in his new capital. He had the benefit of being able to rebuild the city of Constantinople to suit his own vision and sought out a variety of sources upon which to draw for its creation. Once he established himself in the city, renamed Istanbul, Mehmed encouraged trade opportunities with the West by commissioning public and private works from some of the greatest Renaissance artists of the time. His patronage prompted succeeding sultans to embrace the talents of Western artists, though none would rival his enthusiasm or his collection.

Sultan Mehmed II developed an interest in areas of nonIslamic study during his youth. He acquired knowledge in many subjects but showed particular interest in both ottoman and European art, architecture, philosophy, literature, 
history, military engineering, geography, and religion. ${ }^{83}$ Though he was a slow and reluctant learner as a child, his adult thirst for knowledge was unparalleled among the royalty of the Ottoman Empire. He defied convention and "consorted with Hurufi dervish missionaries from Iran, who were spreading heterodox ideas about the divine Logos and the divinity of man." Mehmed II was also tutored in Classics and the cultures of the West in addition to his Islamic studies. "Aside from Muslim teachers, Mehmed had two tutors, one schooled in Latin, the other in Greek, who just prior to the fall of Byzantium read to him daily from "Laertius, Herodotus, Livy, Quintus Curtius, Chronicles of the Popes, Emperors, the Kings of France and the Lombards." ${ }^{84}$

\section{Art of Conquest}

When Mehmed II conquered Constantinople in 1453, he didn't want to destroy the city, its walls, or its treasures since he was prepared to move in. He offered Emperor Constantine XI Palaeologus Dragases the opportunity to surrender because under Turkish law, "fortresses, towns or cities that were not taken by force could not be pillaged or their inhabitants taken prisoners." Constantine, however, refused to surrender and died as the last Byzantine Emperor of Constantinople as the Muslims laid siege to the city. ${ }^{85}$ The Emperor's decision would have a profound effect on the future of the city and its inhabitants.

The Byzantine historian Kritovoulos recorded the

\footnotetext{
83 Julian Raby, "East and West in Mehmed the Conqueror's Library," Bulletin du Bibliophile, (1987): 297-321.

${ }^{84}$ Julian Raby, "A Sultan of Paradox: Mehmed the Conqueror as a Patron of the Arts," oxford A.J. vol. 14, no. 1, (1982): 3-4.

${ }^{85}$ Aptullah Kuran, The Mosque in Early Ottoman Architecture (Chicago: The University of Chicago Press, 1968) 12.
} 
brutality and desecration suffered at the hands of the Muslims in the conquest of Constantinople. Men, women, and children were disgraced and tortured, and were either taken as slaves or killed. The churches were plundered, while the relics and remains of those buried there were destroyed. Mehmed ordered a stop to the plundering three days after taking the city, horrified by the acts of viciousness and disrespect his men had performed against the city and its people. He compared the city's capture to those of the cities of Troy, Babylon, Carthage, Rome, Jerusalem, and even the loss of Constantinople to the Latins, but none was subject to such horrendous acts as those the Muslims had perpetrated. ${ }^{86}$

After this the Sultan entered the City and looked about to see its great size, its situation, its grandeur and beauty, its teeming population, its loveliness, and the costliness of its churches and public buildings and of the private houses and community houses and of those of the officials. He also saw the setting of the harbor and of the arsenals, and how skillfully and ingeniously they had everything arranged in the City - in a word, all the construction and adornment of it. When he saw what a large number had been killed, and the ruin of the buildings, and the wholesale ruin and destruction of the City, he was filled with compassion and repented not a little at the destruction and plundering. Tears fell from his eyes as he groaned deeply and passionately: "What a city we have given over to plunder and destruction! "87

Mehmed initiated repopulating and rebuilding campaigns in an effort to transform the city into a more powerful and glorious state than it had previously been. The city needed to be worthy of the Ottoman sultan and be able to fulfill the role of capital of Europe and Asia once he completed his

\footnotetext{
${ }^{86}$ Kritovoulos, History of Mehmed the Conqueror, C. Riggs trans., (Greenwood Publishers, 1970) 71-80.

${ }^{87}$ Kritovoulos 71-80.
} 
conquests in the west. He offered tax breaks, land, houses, and even churches as residences to those settling in the city. He desired diversity in the population and made provisions for all the groups returning to the city. He called not only for Muslims, but for Christians and Jews as well.

So many of the inhabitants had been carried off from Constantinople that the ancient capital was seriously depopulated, a situation which Mehmed was determined to correct as quickly as possible. Siileyman Bey was commissioned to clean the city, to repair the damaged walls, to adapt the city administration to Turkish ways, to appoint Turkish officials, and especially to replenish the population by bringing back former inhabitants and by newly settling others. ${ }^{88}$

Mehmed allowed the continued worship of all the religions in the city without fear of persecution. His views on religious freedoms, which were fundamental Muslim principles outlined by Mohammad, greatly influenced the welfare of the city and drew many people to settle there. Mehmed installed Gennadius as Patriarch of the Christian church and gave him "the rule of the church and all its power and authority, no less than that enjoyed previously under the emperors. Furthermore the Sultan gave back the church to the Christians, by the will of God, together with a large portion of its properties." ${ }^{89}$ In addition to the appointment of Gennadius as Patriarch of the Christian church, Mehmed appointed Moshe Capsali to the position of chief rabbi over the Jewish congregations of Istanbul. ${ }^{90}$ His commitment to the preservation of religious freedom made Istanbul a haven for immigrants fleeing persecution in their home countries. "The years that

\footnotetext{
${ }_{88}$ Franz Babinger, Mehmed the Conqueror and His Time, (Princeton: Princeton University Press, 1978) 103.

${ }_{89}$ Kritovoulos 83-95.

${ }_{90}$ Babinger 106-107.
} 
followed witnessed a massive emigration of Jews to the Turkish paradise, especially from Germany. Certain countries, Italy in particular, prevented their Jews from leaving. ${ }^{91}$

Mehmed claimed the Byzantine throne when he conquered Constantinople. He saw himself as the legitimate successor to the emperor and tried to preserve and continue aspects of the Byzantine state. As the new Byzantine emperor, he felt a responsibility to uphold many of the traditions. He let the Patriarchate continue to govern the Christian population and allowed the three day celebration of Easter to continue with his blessing. "Under Mehmed the borders of the Ottoman Empire coincided strikingly with those of the Byzantine Empire at its height, just as the decline of both empires was marked by a similar crumbling away of border territories." 92

Mehmed did not wish to stop with his capture of Constantinople; he had designs on Europe and, in particular, Rome. Like his hero Alexander the Great, he wanted to unify Asia, Europe, and the Mediterranean under his rule. For centuries the West had made advances on the East; Mehmed aimed to move from the East to the West and in doing so, to bring Europe under Ottoman rule. He had particular designs on Italy and Germany and owned several maps from which he planned his attacks. The countries of Europe were well aware of Mehmed's intentions toward them, though the further away they were, the less seriously they took the threat. It seems that in 1473 a weakened Austria was within his grasp, should Mehmed have made another attack. This capture would have opened the doors to Europe. Mehmed made repeated attacks

\footnotetext{
Babinger 106-107.

${ }_{92}$ Babinger 416 .
} 
against Hungary and even offered peace treaties in his efforts to gain a path into Europe. He maintained a large network of spies in Italy and Germany but, even with their help, he was unable to achieve his dream. ${ }^{93}$

Mehmed II made an effort to preserve the imperial history of the destroyed Byzantine Constantinople by saving relics, imperial sarcophagi, and regalia. These were "Mehmed's efforts to preserve aspects of the conquered Byzantium in its twin guise as the New Jerusalem and the New Rome." Mehmed also sought to increase his knowledge of Classical culture by studying Ptolemy's Geography and peripatetic philosophy with George Amirutzes. ${ }^{95}$ He even added to his collection of Christian artifacts by commissioning a painting of the Virgin and Child to be executed by Gentile Bellini. His interest in figural paintings and Christian relics was met with animosity by his peers, just as his dalliances as a youth with the fringe group of heterodox thinkers had been. Mehmed's methods, though not universally accepted, nonetheless paved the way for a more culturally diverse empire. Any doubt about Mehmed's interest in Christian art and artifacts is laid to rest by the existence of a detailed record of his collection drawn up by his son, Bayezid II, offering the relics for sale to the King of France after Mehmed's passing. ${ }^{96}$ Mehmed wanted to be more than just an Ottoman prince; he aspired to

\footnotetext{
${ }_{93}$ Babinger 417-503.

${ }^{94}$ Julian Raby, "Pride and Prejudice: Mehmed the Conqueror and the Italian Portrait Medal," Italian Medals: Studies in the History of Art, Ed. J.G. Pollard, (Hanover: University Press of New England, 1987) 171 .

${ }^{95}$ Julian Raby, "Pride and Prejudice: Mehmed the Conqueror and the Italian Portrait Medal," 171.

${ }^{96}$ Julian Raby, "A Sultan of Paradox: Mehmed the Conqueror as a Patron of the Arts," 5 .
} 
be a Renaissance man. He was an open minded and intelligent man with an expansive collection of art and literature.

\section{The Italian Renaissance and the East}

Mehmed II expanded his art collection by commissioning works from a variety of artists, including a venetian masterbuilder, clock makers, intarsia artists, christallini craftsmen, and a scabbard maker. ${ }^{97}$ He also requested the services of the Florentine Filarete (Antonio Averlino), a Renaissance artist, in 1465, as well as the Bolognese engineer and architect, Aristotile Fieravante. Filarete's associations with Brunelleschi, the architect responsible for the double-shell dome of the Florence Cathedral, provided him with knowledge of centralized domed plans. These plans were based on the Greek cross-in-square plans common within the Byzantine Empire. ${ }^{98}$

Mehmed II ordered the construction of the first large imperial complex in Istanbul soon after the conquest. The Fâtih Complex, unlike the complexes of Bursa and Edirne, was strictly organized into a geometric plan. Axially aligned and bilaterally symmetrical, the plan of the complex was unlike anything the Ottomans had constructed, but was very similar to the plans by Italian Renaissance architects. Mehmed expanded on the architectural concepts employed by his father in the Üç Serefeli by including Romano-Byzantine and Italian Renaissance traditions. The mosque at the center of the complex was built with only one semi-dome, but it wasn't

\footnotetext{
97 Julian Raby, "A Sultan of Paradox: Mehmed the Conqueror as a Patron of the Arts" 5 .

98 Guilru Necipoglu, The Age of Sinan: Architectural culture in the

ottoman Empire, (Princeton: Princeton University Press, 2005) 82-94.
} 
the only design submitted. ${ }^{99}$

A project plan for Mehmed II's mosque, drawn on Italian paper datable by its watermark to the second half of the fifteenth century, proposes an alternative design with a central dome resting on two lateral piers and surrounded by three halfdomes. That this inventive plan was meant for Mehmed's mosque can be deduced from its forecourt with domical arcades, an exclusive feature of sultanic mosques. ${ }^{100}$

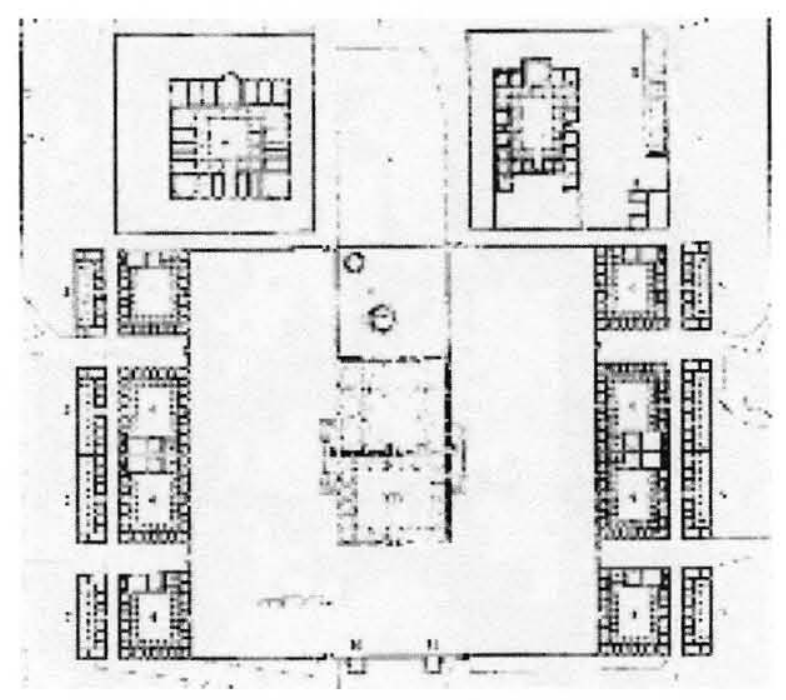

Figure 41. Fâtih Complex, Istanbul (1463-70) Plan.

The layout of Mehmed's complex follows the design for

"Italian Renaissance concepts of ideal planning." The mosque was erected on a platform elevated above vaulted substructures, the remnants of the Byzantine Church of the Holy Apostles, another one of the themes of Renaissance planning. ${ }^{101}$

Filarete was the author of an architectural treatise (c. ${ }_{99}$ Gïlru Necipoglu, The Age of Sinan: Architectural culture in the ottoman Empire, 82-94.

${ }^{100}$ Gulru Necipoglu, The Age of Sinan: Architectural Culture in the Ottoman Empire, 82-94.

${ }^{101}$ Gulru Necipoglu, The Age of Sinan: Architectural Culture in the Ottoman Empire, 82-94. 
1460-64) which Gulru Necipoglu claims likely made its way to the court of the Sultan around the time of the construction of the Fâtih Complex. The complex was built between 1463 and 1470. If not Filarete's treatise, perhaps that of Leon Battista Alberti (c.1452) which was more widely reproduced. Alberti, who "demanded that the principal temple of a city should be centralized in plan, isolated in the center of an ample square, and raised on a podium to elevate its dignity", would surely have approved of the design of the Fâtih Complex. ${ }^{102}$

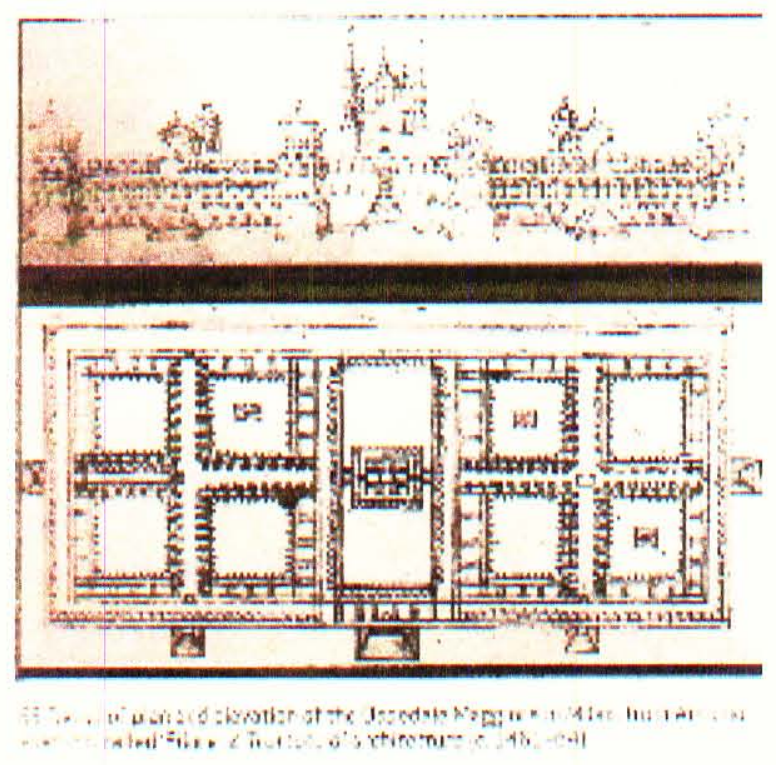

Figure 42. Ospedale Maggiore, Milan (1461-64) Plan and elevation.

Parallels have been drawn between the Fâtih and the plan of Filarete's Ospedale Maggiore in Milan, though it was most likely related to the idealized plan of the Ospedale rather

\footnotetext{
${ }^{102}$ Gulru Necipoglu, The Age of Sinan: Architectural culture in the ottoman Empire, 82-94.
} 
than the actual structure..$^{103}$

In Rome, during the reign of Mehmed's son (1481-1512), the new St. Peter's became "the first grand cathedral church of Italy designed according to a centralized plan, a crossin-square, covered by a large dome surrounded by four smaller ones."104 Bramante designed the centralized plan for Pope Julius II.

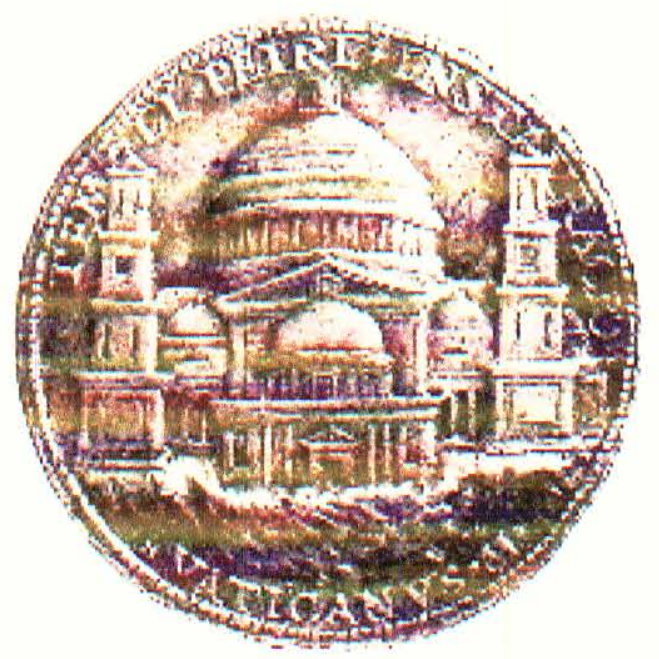

Figure 43. St. Peter's, Rome, Medal depicting elevation.

The plan and elevation, depicted on a medal, bear a striking resemblance to Hagia Sophia and consequently the mosque of Mehmed II. The two towers appear like minarets framing the church. Pope Julius II apparently requested that the new church be built in the guise of the great structures of Rome and Constantinople. In this way, he was reuniting the two imperial cities under Christianity, just as Mehmed II

\footnotetext{
103 Julian Raby, "A Sultan of Paradox: Mehmed the Conqueror as a Patron of the Arts," 7. Franz Babinger disputes this reasoning in his book, Mehmed the Conqueror and His Time. ${ }^{104}$ Gulru Necipoglu, The Age of Sinan: Architectural Culture in the Ottoman Empire, 89-90.
} 
sought to do under Islam. ${ }^{105}$

The centralized plan that Bramante initially proposed was soon translated into a Latin-cross plan. This contributed to the vacillation between centralized Greek-cross and longitudinal Latincross plans proposed by successive architects throughout the construction of the new St. Peter's, which was resolved in the end in favor of Michelangelo's central plan. ${ }^{106}$

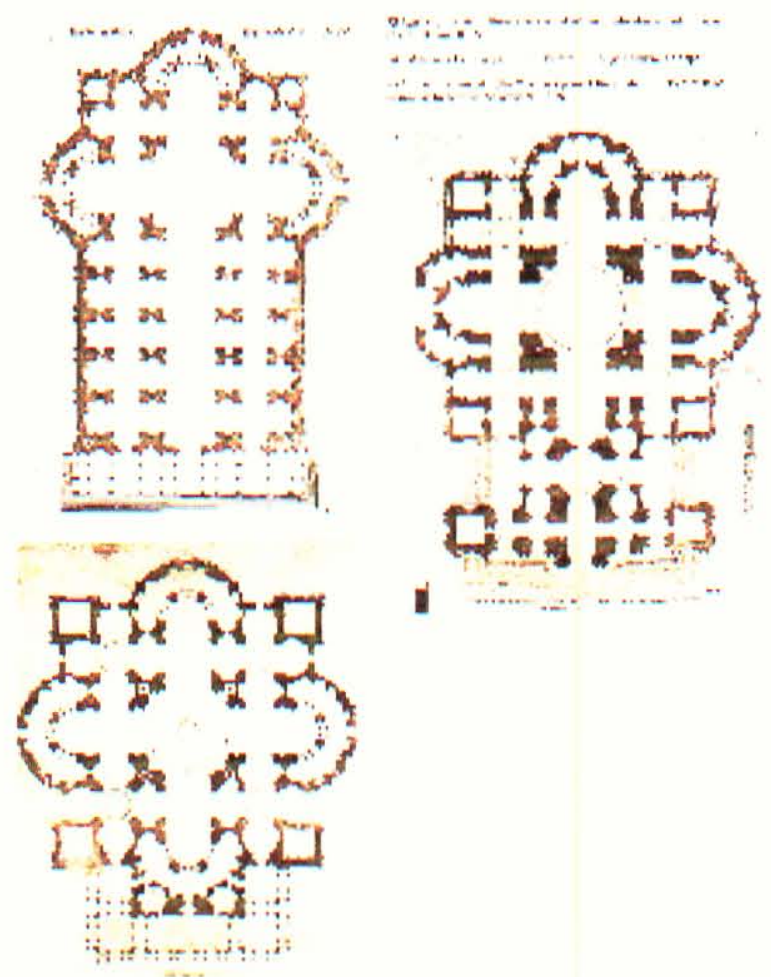

Figure 44. St. Peter's, Rome, Suggested plans.

${ }^{105}$ Gulru Necipoglu, The Age of Sinan: Architectural culture in the Ottoman Empire, 82-94.

${ }^{106}$ Gulru Necipoglu, The Age of Sinan: Architectural Culture in the ottoman Empire, 82-94. 

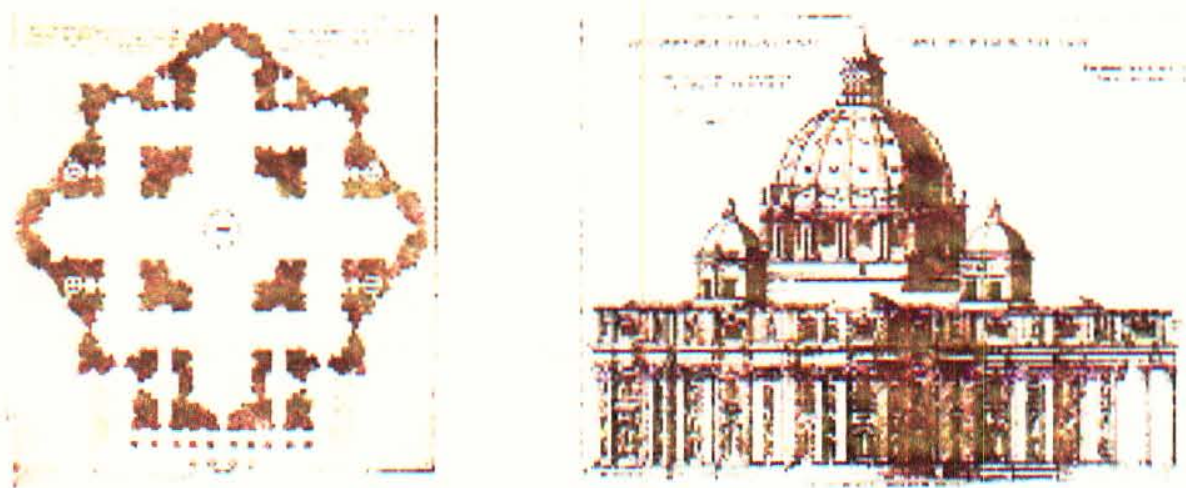

Figure 45. St. Peter's, Rome, Michelangelo's plan and elevation.

For his design of the dome of the new St. Peter's, Michelangelo studied the domes of the Florence Cathedral, the Roman Pantheon, and most likely of Hagia Sophia. ${ }^{107}$

In addition to the cross-cultural transmission of architectural concepts, the Ottomans opened up foreign trade in other areas. Trade agreements were made with Florence during the 1460s and 1470s, but soon Ottoman supply and demand exceeded the production and consumption capabilities of that city. In 1478 Mehmed responded to a call for help from Lorenzo de' Medici. Guiliano de' Medici's assassin was seeking refuge in ottoman territory. Mehmed captured and returned the fugitive to Florence, helping to put an end to the Pazzi conspiracy. Lorenzo rewarded Mehmed for his help with a portrait medal of the sultan.

\footnotetext{
${ }^{107}$ Gulru Necipoglu, The Age of Sinan: Architectural culture in the ottoman Empire, 82-94.
} 

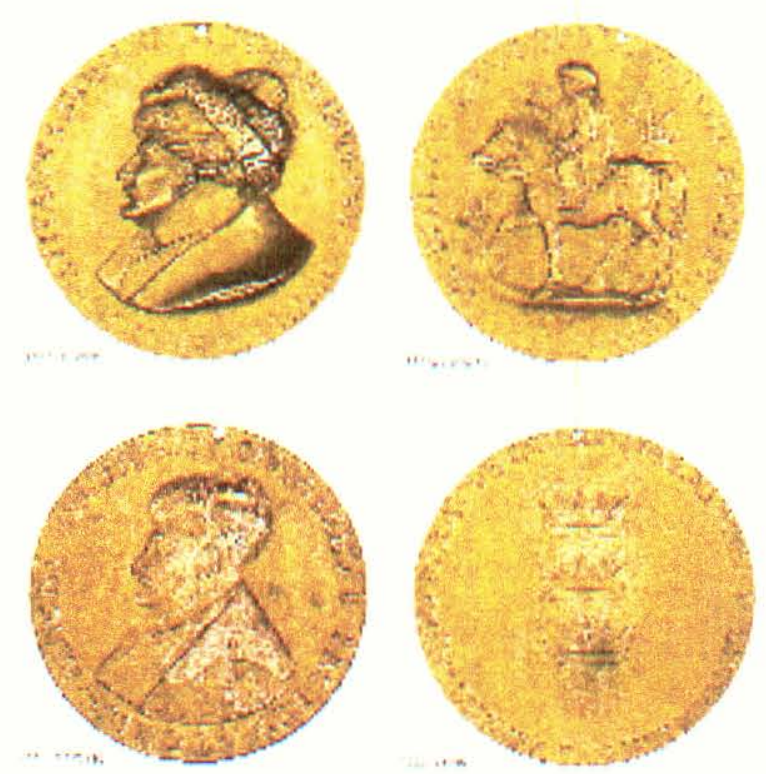

Figure 46. Costanzo de Ferrara's and Bernini's Medals of Mehmed II.

This became the first medal of many for Mehmed, and it influenced him to commission portrait medals on his own to disseminate his image throughout Europe in a traditionally European manner. ${ }^{108}$ "In fact, no other Renaissance prince, whether in Italy or Germany, had such a number of artists sculpt medallions of him." ${ }^{109}$

After the Ottomans made peace with Venice in January 1479, the cross-cultural transmission of art, culture, and craft between the Ottoman empire and the West increased exponentially. Mehmed II sent requests for artists to Venice almost immediately. The Venetians responded by sending their best painter, Gentile Bellini, accompanied by a sculptor, in August 1479. ${ }^{110}$ The Venetian artists were preceded by

\footnotetext{
${ }^{108}$ Rosamond Mack, Bazaar to Piazza: The Islamic Trade and Italian Art 1300-1600, (Berkeley: University of California Press, 2002) 23.

${ }^{109}$ Julian Raby, "A Sultan of Paradox: Mehmed the Conqueror as a Patron of the Arts," 3-4.

110 Mack, Bazaar to Piazza: Islamic Trade and Italian Art 1300-1600 23.
} 
Costanzo da Ferrara in 1475, sent by Ferrante I of Naples. The Veronese artist Matteo de' Pasti was sent in 1461 by Sigismondo Malatesta of Rimini, but he was captured by the Venetians before his arrival in Istanbul and was compelled to return home. ${ }^{111}$

Mehmed's patronage of artists, important in the establishment of patterns of Ottoman dynastic patronage, went far beyond his well-known invitation to the Signoria to send Gentile Bellini to his court. One of the greatest Renaissance patrons, he commissioned medals from Italian artists and amassed an unparalleled library of books in European and Islamic languages. During his reign, communities of craftsmen were established in many categories, including bookbinders and calligraphers, silk- and carpetweavers, metalworkers and painters. ${ }^{112}$

Trade with Florence and Venice allowed the Ottomans access to luxury textiles, including silks and velvets, in exchange for providing a market for Turkish spices. "Display of Italian textiles was consistent with the imperial image, advanced by Mehmed II and Süleyman I, of a great new eastern Mediterranean and European power. Manuscript illuminations show that Italian-style textiles were worn at both their courts." 113

Mehmed's pursuit of foreign art was not well received by everyone in his empire. "Mehmed's patronage had religious and political implications. Many resented his advancement of foreign talent. Others must have found the European figural influence objectionable."114 Mehmed's own son, Bayezid II, disapproved of his actions and accused him of not believing

\footnotetext{
${ }_{111}$ Mack, Bazaar to Piazza: Islamic Trade and Italian Art 1300-1600 157.

112 "Mehmed II," Grove Dictionary of Art Online

113 Mack, Bazaar to Piazza: Islamic Trade and Italian Art 1300-1600 174175.

114 Julian Raby, "A Sultan of Paradox: Mehmed the Conqueror as a Patron of the Arts," 7-8.
} 
in Muhammad. His harsh words were followed by actions. Upon Mehmed's death, Bayezid sold off his father's collection of paintings and relics. He did however, admire his father's ability to rebuild and repopulate the city. "By his repopulating he established the multiracial and multisectarian character of the Ottoman city for more than 400 years."115 "The influence of Mehmed's private patronage was short-lived; the repercussions of his public patronage can still be sensed today."

\section{Legacy of the Fâtih}

Mehmed's successors made small attempts to continue the improvement of cultural relations between the East and the West by occasionally inviting foreign artists to their courts. Despite his rejection of Mehmed's patronage, Bayezid II requested both Michelangelo and Leonardo da Vinci to come to Istanbul and build a bridge for him across the Golden Horn in 1506 but, neither man made the trip. Michelangelo was invited again in 1519 to join Florentine painter Tommaso di Tolfo in the court of Selim I (r. 1512-20) in Edirne. Sultan Suileyman I also requested the services of Italian artists and commissioned jewel-encrusted regalia from Venice. ${ }^{117}$

\section{Chapter Summary}

Mehmed's patronage was invaluable in providing an outlet for Ottoman products and disseminating the imperial ottoman image throughout Europe. Through his deeds and public works

\footnotetext{
$\overline{115}$ Julian Raby, "A Sultan of Paradox: Mehmed the conqueror as a Patron of the Arts," 7-8.

${ }^{116}$ Julian Raby, "A Sultan of Paradox: Mehmed the Conqueror as a Patron of the Arts," 7-8.

117 Mack, Bazaar to Piazza: Islamic Trade and Italian Art 1300-1600 174175 .
} 
he laid the foundation for the successful continuation of the Ottoman Empire, economically, militarily, and artistically. He drew on the knowledge of Renaissance architects in his design of the Fâtih Mosque Complex. This first imperial complex in Istanbul would influence the construction of imperial mosques in the sixteenth century. With a shared respect for Romano-Byzantine traditions, Renaissance and Ottoman architects would follow similar paths towards new architectural styles. Mehmed's openness to the arts of Europe demonstrated the Ottoman willingness to apply various concepts to their art and architecture in the pursuit of excellence. 
CHAPTER V

THE ROAD TO REVIVAL

\section{Staking Claims}

In 1453, under the leadership of Sultan Mehmed II, the Ottomans laid siege to Constantinople. By the end of the 29 th of May, what little had been left of the Byzantine empire was no more. The Ottomans had finally achieved their long sought goal of conquering the city of Constantinople for themselves and for Islam. Later renamed Istanbul, the city became the last of the Ottoman capitals and remained so until the formation of the Turkish Republic in 1924. The besieged city, however, left little for the Ottomans to claim. After the conquest, Mehmed II was given the sobriquet Fâtih, which means The Conqueror. He had the benefit of a nearly blank slate upon which to build his new empire. The latins of the Fourth Crusade had exacted a brutal toll on the city well before the arrival of the Ottomans, who merely completed its destruction.

Immediately upon his arrival, Mehmed II sought to revive the fallen capital through building campaigns and incentives directed at repopulating the city. His first task, however, was to assign a congregational mosque. Recognized as a symbol of authority and religious significance, Justinian's Byzantine jewel of Hagia Sophia was converted into the center of Islamic worship and renamed the Ayasofya Camii in 1453 . The Church of Hagia Sophia became the first imperial mosque 
in Istanbul immediately upon the arrival of Mehmed II. It would not, however, be the only Christian church forced to surrender to Islam. The Muslims were tolerant of the Christians and their faith allowing the continuation of worship and the patriarchate, but they had little hesitation about claiming Byzantine religious structures for themselves.

\section{Ayasofya Camii}

The Church of Hagia Sophia remained an important monument even after the construction of new imperial mosques. Revered as an historical monument, it transcended time and religion to become integrated into the fabric of ottoman state and society. Under the protection of the sultans, Hagia Sophia became a symbol of Islam in representing the culmination of religious progress. ${ }^{118}$ Mehmed II wanted to reunite Constantinople and Rome under a new Islamic empire. "In this unique building, past and present were juxtaposed to invite a recognition of the Ottoman sultans as the successors of the Byzantine emperors and of the triumph of Islam over Christianity."119

Mehmed, in an attempt to prove his position as rightful heir to the Byzantine Empire and to justify the appropriation of Hagia Sophia, ordered a new history to be written to bind the architecture and its new religious context to each other by combining fact with myth. These legends "attempt to justify Hagia Sophia's conversion into a royal mosque by complementing its Christian associations with Islamic ones and by emphasizing its prestigious imperial past, which made

\footnotetext{
${ }_{118}$ Ahunbay and Ahunbay, "Structural Influence of Hagia Sophia on Ottoman Mosque Architecture," 179.

${ }^{119}$ Necipoglu, “The Life of an Imperial Monument: Hagia Sophia after Byzantium," 198 .
} 
it a potent symbol of universal sovereignty."120

The myths, originally recorded by Yusuf bin Musa (1479) and Semsïddin (1480), originate from the belief that the Prophet Mohammed prophesied that Constantinople would one day become a Muslim city. ${ }^{121}$ One legend provided a link to the great architecture of Solomon who is revered as a prophet by Muslims. The story alleges that Hagia Sophia was built on a site sanctified by Solomon and using spolia from his structures. Justinian supposedly built Hagia Sophia after receiving a vision from God telling him to construct the church atop the site of an ancient temple in order to symbolize the supremacy of Christianity over paganism. ${ }^{122}$ At the completion of construction of his great church Hagia Sophia, Justinian is reported as saying, "Solomon I have vanquished thee."123 As the creation of the first Christian church on the site signaled a defeat of paganism and an intermediate stage of religious development, the reconsecration by the Muslims completed the transition by finally realizing the Islamic nature of the building and of the ultimate superiority of the religion. ${ }^{124}$

A corollary to the aforementioned myth claims that the collapse of the half-dome above the apse in Hagia Sophia occurred on the night of the Prophet Mohammed's birth.

\footnotetext{
${ }^{120}$ Necipoglu, "The Life of an Imperial Monument: Hagia Sophia after Byzantium,"198-99.

Necipoglu, "The Life of an Imperial Monument: Hagia Sophia after Byzantium,"198-99. For the early ottoman texts see Felix Tauer, "Notice sur les versions persanes de la légende de 1'édification d'Ayasofya," in Fuat Köprülü Armagani (Istanbul, 1953). 122 Necipoglu, "The Life of an Imperial Monument: Hagia Sophia after Byzantium,"199-202.

${ }^{123}$ C. Mango, "Byzantine Writers on the Fabric of Hagia Sophia," Hagia Sophia, R. Mark and A. Cakmak, (New York: Cambridge University Press, 1992) 45. ${ }^{124}$ Necipoglu, "The Life of an Imperial Monument: Hagia Sophia after Byzantium," 200.
} 
Before it could be rebuilt, the Byzantines had to send an envoy to the Prophet and request that he sanction the project. Mohammed gave his consent along with his saliva, sand from Mecca, and water from the holy well at the Kaaba to create a special compound to be used as mortar in the church. Because of its divinely inspired destiny and the blessing of the Prophet, the church was allowed to remain significantly intact throughout the process of conversion and to be preserved and protected for its historical and religious significance. Even the name, Hagia Sophia, was preserved since it was believed to have been communicated to Justinian in his vision. This portion of the myth incorrectly assumes that Justinian named the church Hagia Sophia. In fact, the name had been used for Constantine's church on the same site. These legends all imply that Justinian's Church of Hagia Sophia had "always been the sanctuary of the same God worshiped by Christians and Muslims alike."125

Another legend states that Mehmed II sent architect Ali Neccar to the Byzantine emperor to repair Hagia Sophia three years before the conquest. As recorded by the seventeethcentury Ottoman traveler Evliya Celebi, Neccar reportedly told the sultan on his return to Edirne: "I have secured the cupola of Ayasofya, O Emperor, by four mighty buttresses; to repair it depended on me, to conquer it depends on thee. I have also laid the foundations of a minaret for thee, where I offered up my prayers." Thus, histories were created to confirm the creation of Hagia Sophia in accordance with the blessing of God and the Prophet Mohammed for the intention of fulfilling its destiny to become a mosque.

${ }^{225}$ Necipoglu, "The Life of an Imperial Monument: Hagia Sophia after Byzantium,"199-202. 
Mehmed ordered the relics, crosses, icons, and bells to be removed from Hagia Sophia. While "the figural mosaics on the lower levels were immediately plastered over, the ones situated above or beyond the view of the praying congregations survived almost intact well into the sixteenth century." Mehmed added two minarets, which signified that the building was now an imperial mosque since only persons of royal ottoman blood could use more than one minaret, a marble minbar, and a mihrab which was placed at an angle to the apse in order to align with Mecca. He also had a few inscriptions added to help "announce the new identity of the building."126

\section{Küçük Ayasofya Camii}

The Church of SS Sergius and Bacchus, built by Justinian I (c. 527-536), was transformed into a mosque during the reign of Bayezid II in 1504, and given the name Küçük Ayasofya Camii ('Little Hagia Sophia Mosque'). A five bay portico was added, some windows and entrances were altered, and the interior was plastered over, but in general the building remains substantially intact. This seems a tremendous feat, given the duration of usage, frequency of seismic events, and "the passing of all of Istanbul's rail traffic within 5 meters of its south wall."127

\section{Fenari Isa Camii}

Formerly known as the church of Constantine Lips, in 1496 it was reconsecrated as the Fenari Isa Camii. A few minor changes were made to the church, including the addition

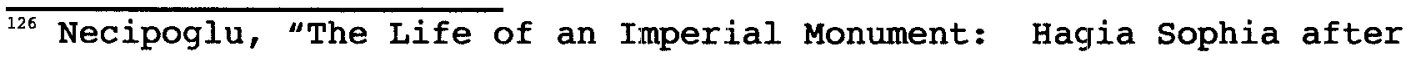
Byzantium," 202-204.

127 Thomas Mathews, The Byzantine Churches of Istanbul: A Photographic Survey 242-243.
} 
of a minaret, the removal of the arcades of the south church, and the elimination of three of the columns of the north church. ${ }^{128}$

\section{Fethiye Camii}

The Theotokos Pammakaristos continued its association with the Greek Orthodox Patriarchate long after the Conquest of Constantinople. It remained the seat of the patriarchy for 112 years after it was moved from the Church of the Holy Apostles in 1456. The church was converted into a mosque by Murad III ( $r$. 1574-1595), and given the name Fethiye Camii in honor of his conquest of Georgia and Azerbaijan. After Mehmed II installed Gennadius as patriarch, the sultan made visits to the church where he discussed religion and politics with him in the parekklesion. ${ }^{129}$ The Theotokos Pammakaristos was subjected to drastic architectural modifications during its conversion into a mosque which left the design of the Byzantine church difficult to recognize. In addition to the erection of a minaret, the interior of the church was gutted and redesigned in an effort to maximize uninterrupted space. ${ }^{130}$

The triple arcades which originally separated the square nave from the ambulatories on three sides were removed and broad pointed arches were substituted; the three apses were destroyed and in their place a domed square room was set obliquely against the eastern end of the building; fenestrations were revised and the walls and piers were hewn back or remade. ${ }^{131}$

As with the main church, the parekklesion was altered in

\footnotetext{
$\overline{128}$ Freely and Cakmak, Byzantine Monuments of Istanbul 176.

129 Freely and Cakmak, Byzantine Monuments of Istanbul 266.

${ }^{130}$ Thomas Mathews, The Byzantine Churches of Istanbul: A Photographic Survey 346-347.

${ }^{131}$ Thomas Mathews, The Byzantine Churches of Istanbul: A Photographic Survey 346-347.
} 
order to increase the interior space. This came about by the removal of the inner wall and the columns to the north. The changes within the parekklesion were not as dramatic as those of the main church and, after some restoration work, it has been restored to most of its former glory. ${ }^{132}$

\section{Fâtih Camii}

The Fâtih complex was the first large imperial complex built in Istanbul and Mehmed II Fâtih commissioned architect Atik Sinan (Old Sinan, to differentiate him from the more famous architect of the sixteenth century). It was constructed atop the Fourth Hill of the city between 1463 and 1470. The site was the location of the Byzantine Church of the Holy Apostles, which had been the second largest church in Constantinople and the resting place of the Byzantine emperors. It is from here that Mehmed rescued the sarcophagi of the emperors. The church was in a ruined state, so the sultan tore down the remains to create his new complex. Mehmed II Fâtih designed the complex to conform to a strictly symmetrical plan despite historic precedent and the topography of the site. ${ }^{133}$

It has been argued that this new arrangement was due to the presence of Antonio Filarete, who is known to have intended to set out for Mehmed's court in 1465, but this date is two years after the project was initiated. The vast, almost square area measured approximately 325 meters to a side. The mosque lay at the center of an enormous square court, approximately two hundred meters on a side, and was preceded by a forecourt and followed by a garden containing the tombs of the founder and his wife. ${ }^{134}$

\footnotetext{
132 "Fethiye Mosque," Archnet <http://archnet.org/library/sites/onesite.tcl?site id=7171>

133 Blair and Bloom 215-216.

${ }^{134}$ Blair and Bloom 215-216.
} 
The complex centered on the mosque included such structures as madrasas, a hospital, hospices, a soup kitchen, baths, a caravanserai, and a library. ${ }^{135}$

Mehmed's personal interest in learning and education influenced his design of the Fâtih Mosque complex. Rather than place Sufi hospices central to the complex and surrounding the mosque, as had been the tradition, he relegated them to secondary localities within the precinct, instead placing the sixteen madrasas (colleges) in the coveted positions nearest the sanctuary. "The endowment deed stresses that the sultan built the numerous madrasas to repair and fill with light the house of knowledge and to convert the imperial capital to a realm of learning."136

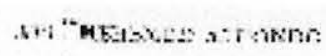

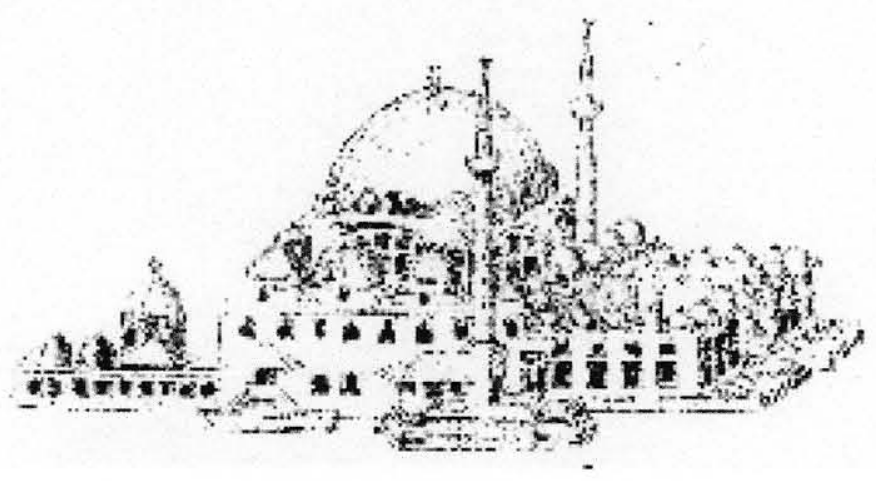

Figure 47. Fâtih Camii, Istanbul (1463-70) Elevation drawing.

The Fâtih Mosque Complex repeatedly fell victim to the earthquakes that plague the region, and was ultimately destroyed in the earthquake that shook Istanbul on May 22, 1766. The damage sustained in this earthquake and the

\footnotetext{
135 "Fatih Complex," Archnet <http://archnet.org/library/sites/onesite.tcl?site_id=2958>

${ }^{136}$ Blair and Bloom 215-216.
} 
subsequent reconstruction of the mosque by Mustafa III mean that details of the original mosque structure are dependent upon recorded eyewitness accounts of travelers and chroniclers in histories, sketches, and engravings, and limited archaeological evidence. ${ }^{137}$ One of the often cited sources for reconstruction is the engraving of Melchior Lorich's view of the city in $1559 .{ }^{138}$

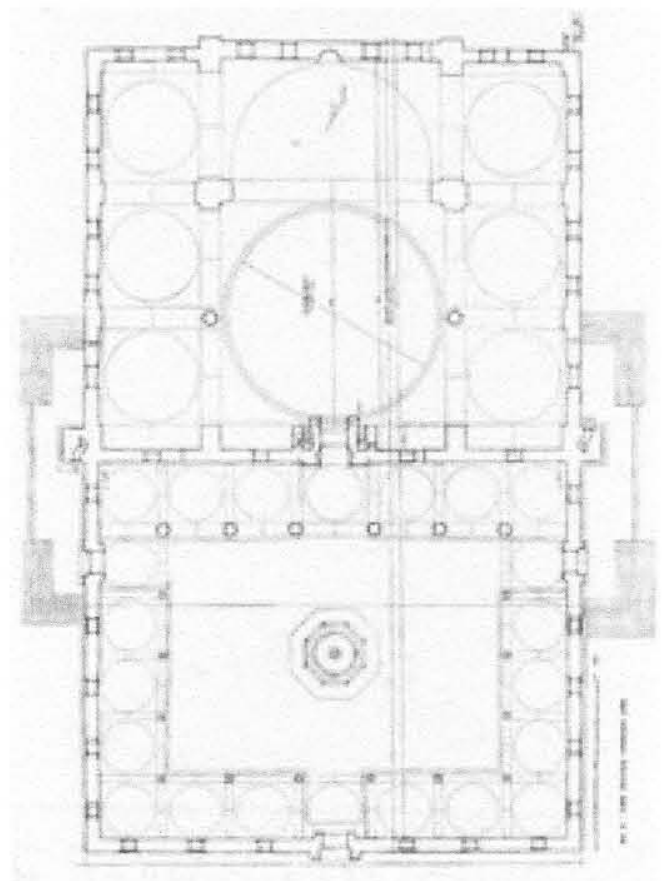

Figure 48. Fâtih Camii, Istanbul (1463-70) Plan.

The mosque was 46 by 33 meters and was preceded by an open courtyard ( 21 by 30.5 meters) surrounded by arcades consisting of 22 domes supported on 18 columns. The largest central dome built by the Ottomans up to that time, 26 meters in diameter, crowned the prayer hall. It was a significant achievement for a first attempt, smaller than Hagia Sophia's

\footnotetext{
137 "Fatih Complex," Archnet <http://archnet.org/library/sites/onesite.tcl?site_id=2958>

${ }^{138}$ Blair and Bloom 215-216.
} 
dome by only five meters. The dome was supported by two massive piers and two large porphyry columns. Above the mihrab was a semidome with the same radius as the main dome. Flanking the central dome were six smaller domes, three on each side. This plan achieved a new level of sophistication for the ottomans. Never before had they paired a semidome with a central dome. This was surely a result of the influence of Hagia Sophia. Also, the main dome was supported on only four points, rather than six, which opened up more space on the floor. ${ }^{139}$

It is reasonable to assume that the Ottomans had knowledge of Justinian's Church of Hagia Sophia prior to the fall of Constantinople, but their architecture fails to reflect any influence by the great church until the conquest. ${ }^{140}$ The fact that the dome of the original Fâtih is just two meters larger in diameter than that of the Üç Serefeli, which was built by Mehmed's father sixteen years earlier, shows a move toward larger domes prior to the conquest of Constantinople. ${ }^{141}$ "Throughout the whole 900 years of Byzantine architecture following the replacement of the dome of St. Sophia after the collapse in 558, none of the domes in any of the churches attained a diameter exceeding 10 meters. This clearly shows the strength of the Ottoman urge towards the creation of a large, unified space."142

Smaller versions of the Fâtih plan may still be seen in the mosques of Rum Mehmed Pasha (1471) in Üsküdar and Atik Ali Pasha (1497) in Istanbul, since the original mosque of the Fâtih was destroyed in the earthquake of 1766 .

\footnotetext{
$\overline{139}$ Blair and Bloom 215-216.

${ }^{140}$ Mainstone 248-249.

${ }_{141}$ Aslanapa 207.

142 Aslanapa 209.
} 


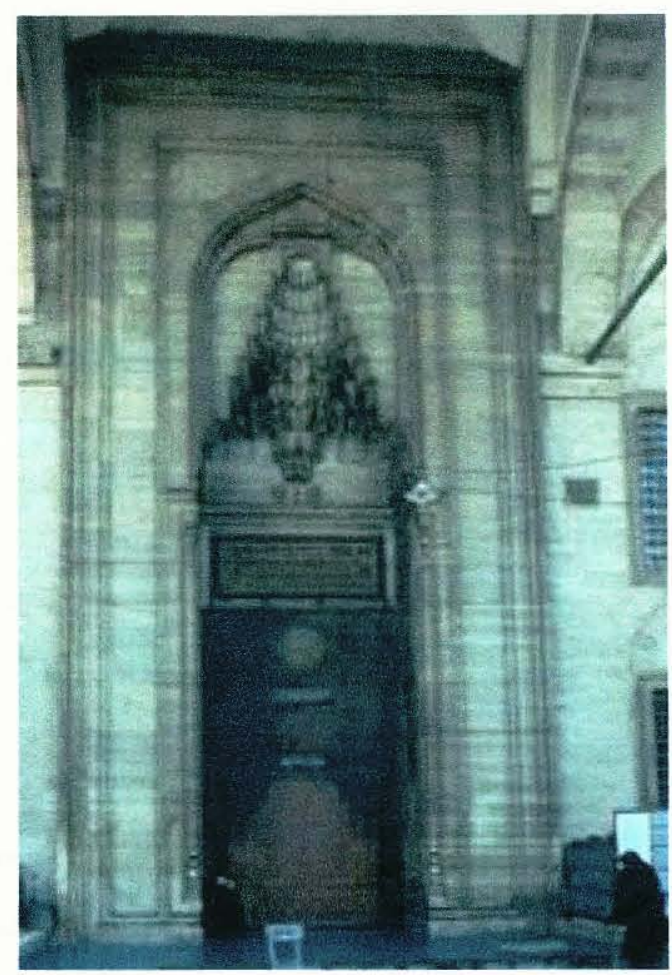

Figure 49. Fâtih Camii, Istanbul (1463-70) Main Portal remaining from original mosque.

There are still some elements remaining of the original Fâtih mosque which were built into the new structure. These details from the courtyard are evidence of the impact of mosque architecture in Bursa and Edirne. The main portal is a virtual copy of the one at Üç Serefeli. ${ }^{143}$ "The inscription on the marble entrance door, resembling the porch of the Üç Serefeli Mosque is the work of Ali bin Sufi, one of the calligraphers of the period of Mehmed II." ${ }^{144}$

There is some dispute concerning the artists of the ceramic tiles decorating the courtyard of the Fâtih Camii. Some historians believe they are the last of the works by the Masters of Tabriz, while others claim they are the early works of tile makers in Iznik. Blair and Bloom suggest that ${ }_{143}$ "Fatih Mosque, Mehmed IIs foundation," Grove Dictionary of Art online 144 Aslanapa 209. 
the polychrome tile lunettes remaining in the courtyard of the Fâtih are the work of the Masters of Tabriz. The underglaze-painted cuerda seca tiles are like those of the Üç Serefeli, but add yellow to a palette of blue, green, and white. ${ }^{145}$ Godfrey Goodwin suggests they are not the later work of the Masters of Tabriz, but are rather early work from Iznik added after the completion of the mosque.. ${ }^{146}$

The engraving by Lorich shows the roof of the Fâtih as a true drum carrying a lipped dome. In contrast, the classical Ottoman mosque doesn't have a true drum. Windows inset within the drum weakened it, requiring the addition of small buttresses between the windows. In addition to these buttresses, turrets were placed in the corners of the roof atop the piers in order to absorb the lateral thrust of the dome and convert it downward. ${ }^{147}$

Kuban sees Ottoman architecture as an organization of mass and a correspondence of upper and lower parts by means of mass, and not a relationship determined by the elements. The core is the duality of the dome set on a square and the dome generates the total space in the building. The interior is therefore an absolute unity. The Ottoman style is geometric and formalist, never ornamental; significant rather than beautiful. Externally, the aim is monumentality. ${ }^{148}$

The 15th century Byzantine historian Kritovoulos of Imbros wrote of this mosque in reference to Hagia Sophia: "The Sultan himself selected the best site in the middle of the city and commanded them to erect a mosque which in height, beauty and size, should compete with the largest and

\footnotetext{
$\overline{145}$ Blair and Bloom 215-216.

146 Goodwin, A History of Ottoman Architecture 127-131.

147 Goodwin, A History of Ottoman Architecture 127-31.

${ }^{148}$ Goodwin, A History of Ottoman Architecture 127-31.
} 
finest temple already existing there."149 The contmporary historian Tursun Beg also commented on Mehmed's conscious decision to draw from the example of Hagia Sophia by writing that the Sultan desired a "great mosque based on the design of Ayasofya which not only encompassed all the arts of Ayasofya, but moreover incorporated modern features constituting a fresh new idiom. Thus, Mehmed II initiated an ongoing dialogue between the Islamic-ottoman architectural heritage and Hagia Sophia that would give birth to a new unique stylistic synthesis."150

Even with its new and innovative approach to roofing, the space within the mosque was somehow lacking. Instead of highlighting the mihrab under its single semidome, the result was rather anticlimactic and unsettling. The initial attempt of the Ottomans to create a spacious domed mosque was a hollow success. Technically the Ottomans had achieved their goal of spanning the sanctuary with a massive central dome, but the interior was still constrained by aisles and the single semidome threw off the balance. The design would be improved upon in later mosques and would come back to the Fâtih, under the reign of Mustafa III, transforming it into the showpiece of Classical Ottoman architecture it had aspired to be. ${ }^{151}$ The Fâtih mosque was built on a plan divided into twelve units. While it was geometrically sound, this design lacked the grace of sixteenth century mosques which were divided into sixteen sections due to the additional domes and semidomes. ${ }^{152}$

\footnotetext{
${ }_{149}$ Gülru Necipoglu, "Challenging the Past: Sinan and the Competitive Discourse of Early Modern Architecture," Mugarnas, vol. 10 (1993) 171. ${ }^{150}$ Gülru Necipoglu, "The Life of an Imperial Monument: Hagia Sophia after Byzantium," 198.

${ }^{151}$ Goodwin, A History of Ottoman Architecture 129-30.

${ }^{152}$ Goodwin, A History of Ottoman Architecture 127-31.
} 


\section{Chapter Summary}

The Ottoman choice to preserve the Byzantine churches initially was one of convenience, but even following the construction of Mehmed's Fâtih Complex and the later imperial mosques, the former churches remained important centers of Muslim worship. The conversion of these churches continued into the sixteenth century with relatively minor adjustments to their plans. Mehmed II acknowledged the influence of Hagia Sophia in his construction of the first imperial mosque complex within the city of Istanbul. The Fâtih represents a stepping stone between the mosques of the Early Ottoman period and the classical ottoman style of the sixteenth century. It is in the Fâtih that the influences of the Byzantines and the Italians find their way into the future of Ottoman mosque architecture. 
CHAPTER VI

THE RISE OF CLASSICAL OTTOMAN ARCHITECTURE

The Sultan Bayezid II, Sehzade, and Süleymaniye mosques are located approximately halfway between the Fâtih and the Ayasofya mosques where they fan in an arc around the former Byzantine Church of Hagia Sophia. In these mosques the Ottoman Classical style differentiated itself and marked the sixteenth century's achievement in creating a new architectural tradition.

\section{Sultan Bayezid II Camii}

Bayezid II (r. 1481-1512) followed his father's lead by building his own large imperial complex from 1500-1505. Unlike the Fâtih Complex, it cascades over the hilly site without regard to geometric placement.

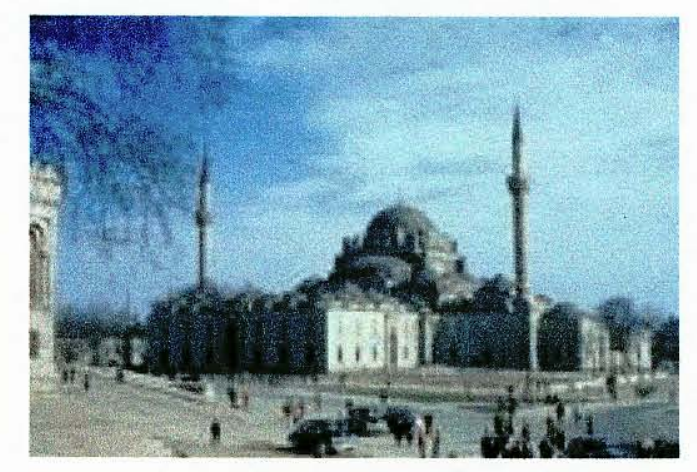

Figure 50. Sultan Bayezid II Camii, Istanbul (1481-1512) Exterior.

The layout of the mosque, however, is governed by geometry. 
It exemplifies a movement toward a more centralized plan. It is "a stepping stone between early Ottoman architecture and classical Ottoman architecture characterized by a centrally planned mosque topped by a central dome held by semidomes on all four sides."153 Like the Fâtih before it, the Bayezid II mosque was preceded by a courtyard. That courtyard, like the one in the plan of the later Fâtih, was from its inception the same size as the prayer hall..$^{154}$

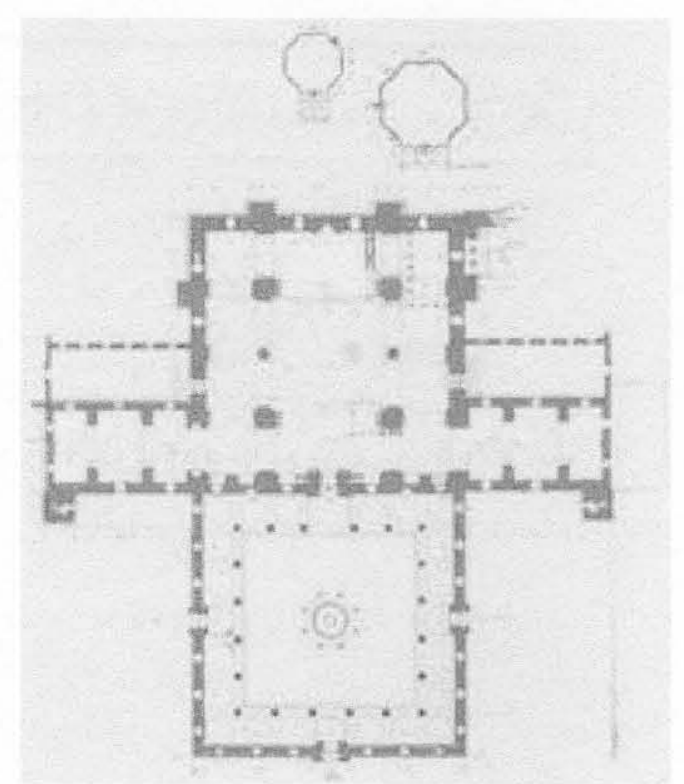

Figure 51. Sultan Bayezid II Camii, Istanbul (1481-1512) Plan.

\footnotetext{
153 "Sultan Bayezid II Complex," Archnet <http://archnet.org/library/sites/one-site.tcl?site_id=7707> 154 "Sultan Bayezid II Complex," Archnet <http://archnet.org/library/sites/one-site.tcl?site_id=7707>
} 


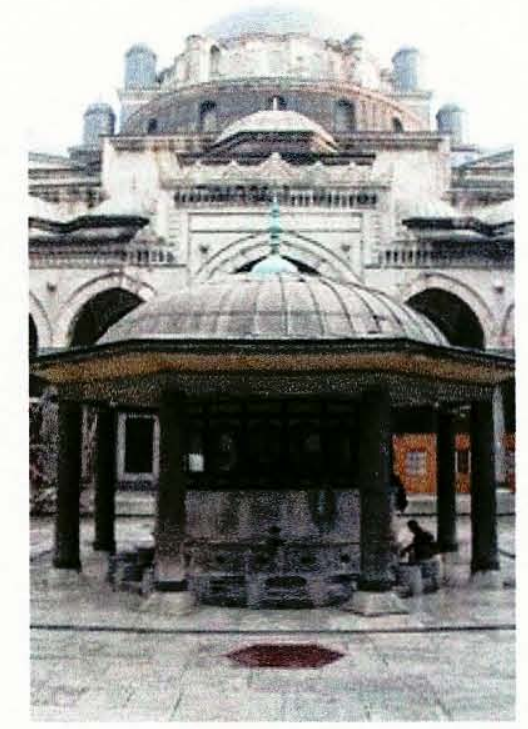

Figure 52. Sultan Bayezid II Camii, Istanbul (1481-1512) Façade from courtyard.

The Ottoman follow-up to the use of the single semidome at the Fâtih Camii was the employment of two semidomes which followed the plan of Hagia Sophia and are in use at the Bayezid II Camii.

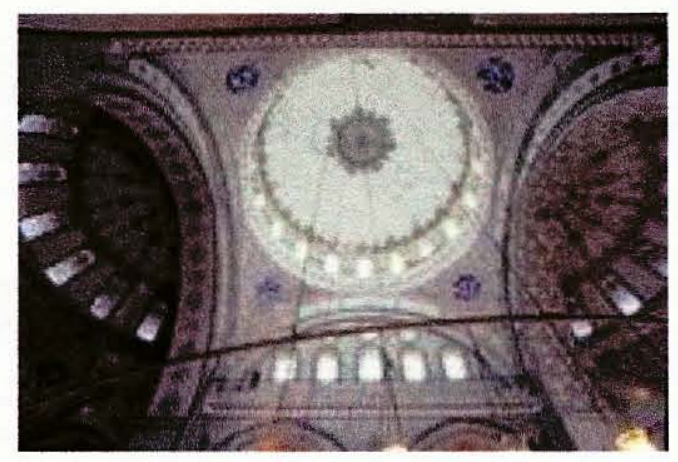

Figure 53. Sultan Bayezid II Camii, Istanbul (1481-1512) Interior view of central dome and semidomes.

The Sultan Bayezid II Camii consists of a domed central space extended by two semidomes along the qibla axis, rreminiscent of the plan of Hagia Sophia. The interior has side arcades covered with four smaller domes, two of which equaled the 
span of the central dome. The central dome which is only 16.8 meters in diameter, much smaller than the Fâtih and the Hagia Sophia, rises to a height of 44 meters and is carried on four piers interspersed with the colonnades separating the central space from the side aisles. ${ }^{155}$ The Bayezid II Camii uses a pure modular geometry but looks archaic when compared to the more refined taste of Sinan in the later Sehzade. ${ }^{156}$ The use of domes on religious buildings was not an unusual phenomenon, but the combination of them in association with semidomes was not a common practice..$^{157}$

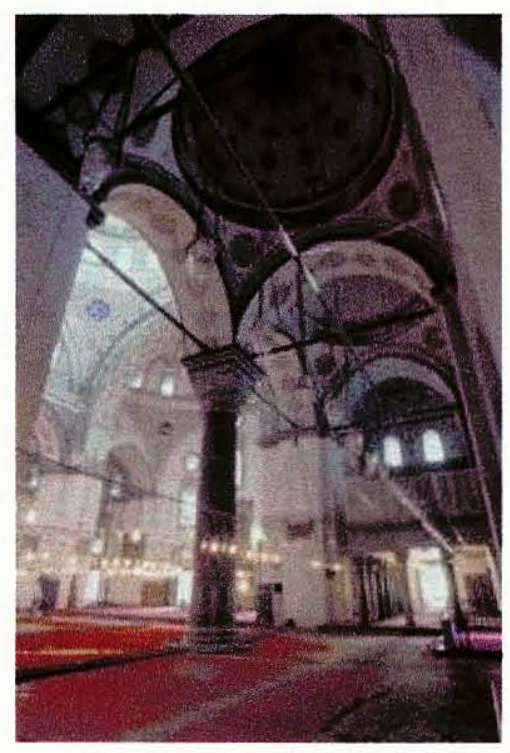

Figure 54. Sultan Bayezid II Camii, Istanbul (1481-1512) Interior looking toward qibla wall from southwest arcade.

Somehow this mosque still appears elongated, even though the space is square and the interior colonnades have been reduced to a single column between the piers. In future mosques, the two flanking semidomes would be increased to

\footnotetext{
155 "Sultan Bayezid II Complex," Archnet <http://archnet.org/library/sites/one-site.tcl?site_id=7707> ${ }^{156}$ Dogan Kuban, "The Style of Sinan's Domed Structures," Muqarnas vol 4 (1987) 83 .

${ }^{157}$ Ahunbay and Ahunbay 180.
} 
four, as in the example of the Sehzade Camii, giving total balance to the form of the Ottoman mosque. The architects had mastered the engineering, sinan would take the next step and create beauty in the details. ${ }^{158}$ The Sultan Bayezid II Camii, unlike Hagia Sophia, does not attempt to hide its basic support elements. "The two great columns which help support the tympana do not obstruct, and the side aisles are exposed and not masked as they are at Hagia Sophia."159 This mosque does not yet achieve the grace and grandeur of Classical Ottoman mosque architecture and, though it follows the plan of Hagia Sophia, it is still only a simplified version of a similar design. The added stability of two semidomes was not enough to protect the dome from earthquakes, for the mosque suffered damage in the earthquakes of 1509 and $1766 . .^{160}$

\section{Sinan}

Not to be confused with Atik Sinan, the architect of the Fâtih, Sinan would pioneer the classical style of Ottoman mosque architecture. Born a Christian in Anatolia around 1497, Sinan was recruited in his youth to serve in the Jannissaries, the elite corps of the Ottoman army, under Sultan Süleyman. He became a Muslim and was educated in carpentry and building techniques. He showed promise as an engineer who designed bridges, aquaducts, and other structures while on campaigns. The campaigns provided Sinan with the opportunity to travel and experience the architectural styles of various cities in Turkey, which he

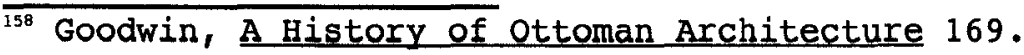
159 Goodwin, A History of Ottoman Architecture 170-171.

160 Ahunbay and Ahunbay 181.
} 
combined with his knowledge of Byzantine and Ottoman structures in Istanbul. After his return to Istanbul, Sïleyman charged Sinan with the task of building several mosques for him. This was the start of a very long and successful career. ${ }^{161}$

Sinan did not like the idea of ambulatory space and sought to create in his mosques a unified whole, free of screens like those found in Hagia Sophia. He favored vast centralized spaces that emphasized the vertical over any other direction. ${ }^{162}$ Sinan readily admitted in his writings his admiration for and desire to surpass Hagia Sophia in his architecture. In his own journals, he called Hagia Sophia "unequaled in the world." He also admitted to using it as a model though he never copied it. Sinan made the comment that no mosque, built in the style of Hagia Sophia had achieved any refinement until his own, in the form of the sehzade Camii. ${ }^{163}$ Sinan was even given the commission of repairing Hagia Sophia around 1573. His work probably included the addition of additional buttresses, some fill-ins, and tierods. This was surely an honor for the architect, and gave him the opportunity to study the structure of the building up close. ${ }^{164}$

\section{Sehzade Camii}

The Sehzade Mosque Complex, completed between 1543 and 1548, was built on the order of sultan Sulleyman in honor of

\footnotetext{
${ }_{161}$ John Freely and Augusto Romano Burelli, Sinan: Architect of Suleyman the Magnificent and the ottoman Golden Age (New York: Thames and Hudson, 1992) 15.

${ }^{162}$ Dogan Kuban, "The Style of Sinan's Domed Structures," 77-78.

${ }^{163}$ Gülru Necipoglu, "Challenging the Past: Sinan and the Competitive Discourse of Early Modern Architecture," 172.

${ }^{164}$ Mainstone 102-109.
} 
his son and heir, Mehmet, who died tragically young of smallpox. The word 'sehzade' means 'prince'. It was sinan's first large commission and with it began a long and fruitful career as the Chief Royal Architect of three sultans.

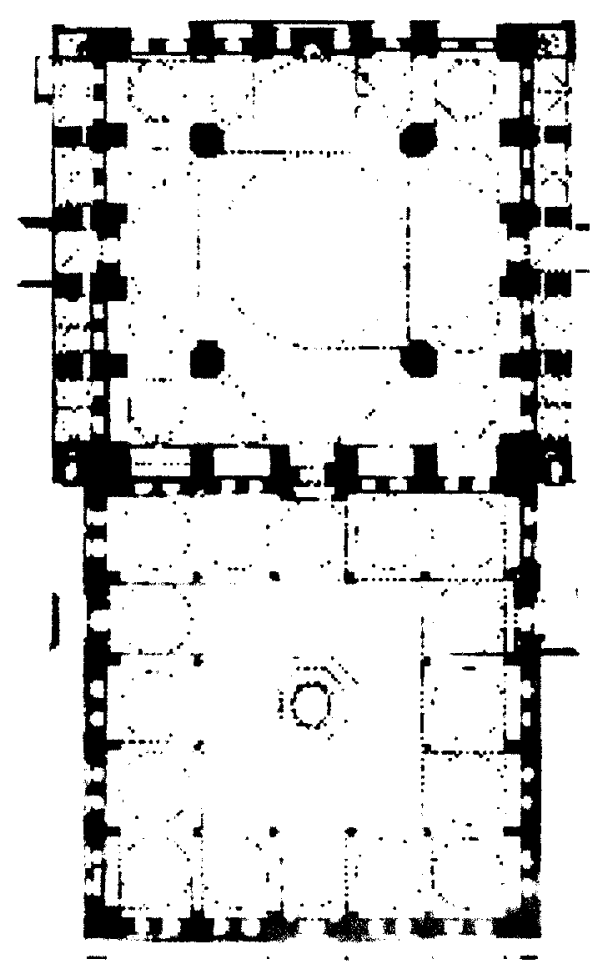

Figure 55. Sehzade Camii, Istanbul (1543-48) Plan.

In the Sehzade Camii, Sinan fully realized the potential of the semidome. The Ottomans surpassed the Byzantines by adopting four semidomes around the central dome in the Sehzade. Sinan eliminated the aisles and, by moving the massive supports to the outside, he opened the space up to its capacity. Though touted as a work of his apprenticeship, the Sehzade beautifully assimilates the goals of ottoman architects. 


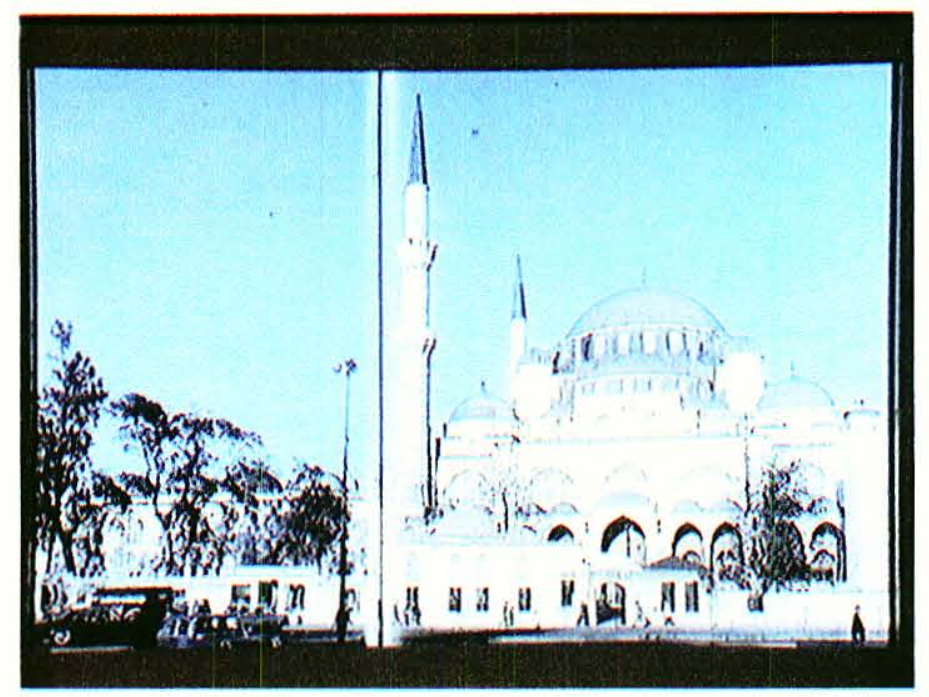

Figure 56. Sehzade Camii, Istanbul (1543-48) Exterior.

Sinan achieved a nearly unified space topped by a cascade of domes and semidomes which is both a reflection of and a response to the architecture of Hagia Sophia. This Ottoman interpretation marks the achievement of a new classical architecture which would reach its zenith thirty years later with the completion of Sinan's Selimiye in Edirne. ${ }^{165}$ The dome of the Sehzade is not the largest of the four Ottoman mosques built in Istanbul and discussed here, but it is perhaps the most important in the evolution of use and form. The central dome is 19 meters in diameter and reaches a height of 37 meters. ${ }^{166}$

The Sehzade has a perfectly symmetrical centralized plan. There are no interior columns to interrupt the vast open space of the prayer hall. The four main piers which support the central dome have polygonal shapes in order to reduce their bulk and to help visually unify the interior.

\footnotetext{
165 Goodwin, A History of Ottoman Architecture 207-208.

${ }^{166}$ Goodwin, A History of Ottoman Architecture 207-208.
} 


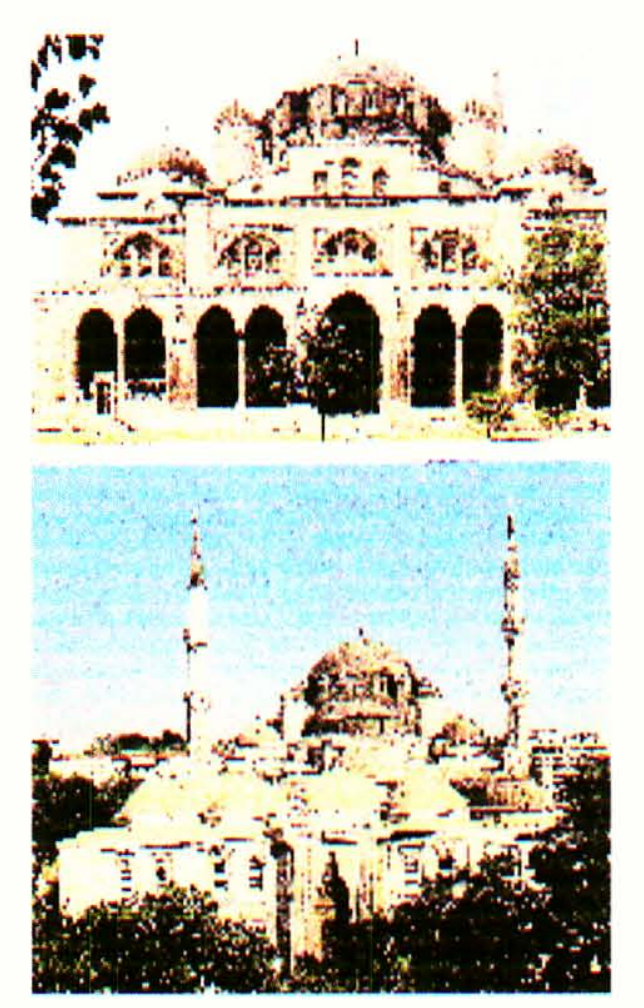

Figure 57. Sehzade Camii, Istanbul (1543-48) Exterior.

The great buttresses are concealed by the exterior walls. The exterior of the structure also no longer appears as massive as the exteriors of earlier mosques. The scale of the Sehzade Camii approaches that of Hagia Sophia, while improving upon the plan of the Sultan Bayezid II Camii by surrounding a central dome with semidomes on each of four sides, with smaller semidomes flanking those. The central dome is now also abutted by three bays rather than two, all elements which combine to form a more graceful structure. ${ }^{167}$

$\overline{{ }^{167} \text { Blair and Bloom 218-219. }}$. 


\section{Süleymaniye Camii}

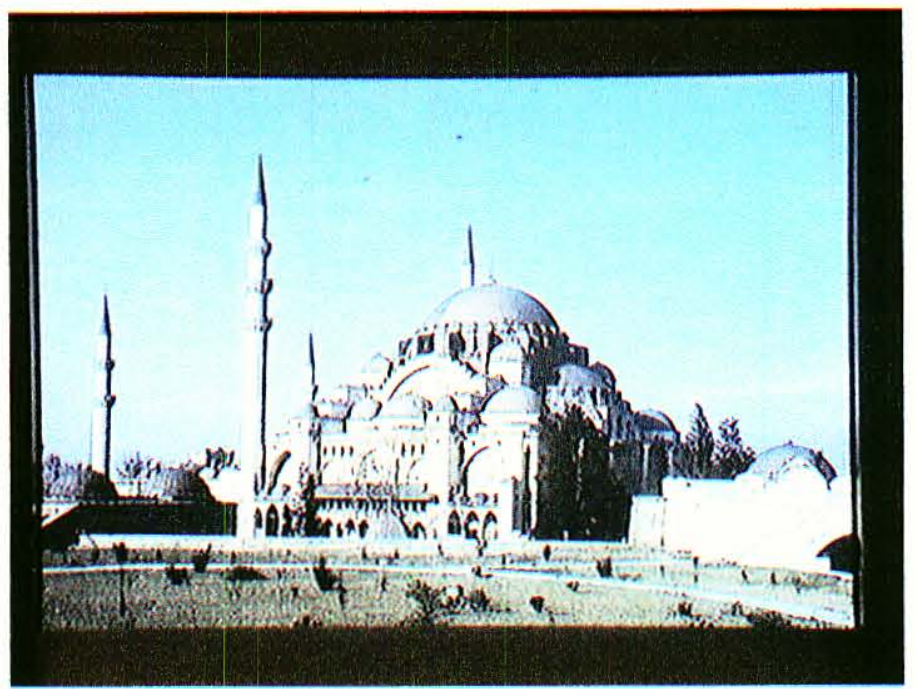

Figure 58. Süleymaniye Camii, Istanbul (1550-57) Exterior.

After the completion of the mosque in honor of his son, Sultan Süleyman the Magnificent commissioned Sinan to build a mosque more splendid than those before it. The Süleymaniye Camii was built between 1550 and 1557 on the Third Hill of Istanbul at the height of Sinan's long career. The Süleymaniye was another attempt by Sinan to revive Hagia Sophia's scheme and reformulate it. ${ }^{168}$ This complex, like the Fâtih which it was designed to resemble, is laid out geometrically. The hill on which it was built was terraced in order to accommodate the buildings in the complex. The plan of the Süleymaniye Camii does away with the uniform side semidomes of the Sehzade and replaces them with three domes, a larger dome in the center. Four exedrae mark the corners of the main axis.

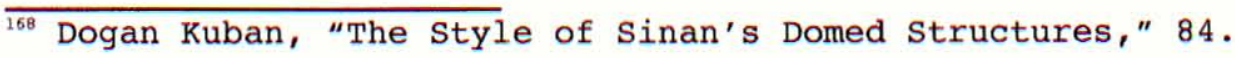




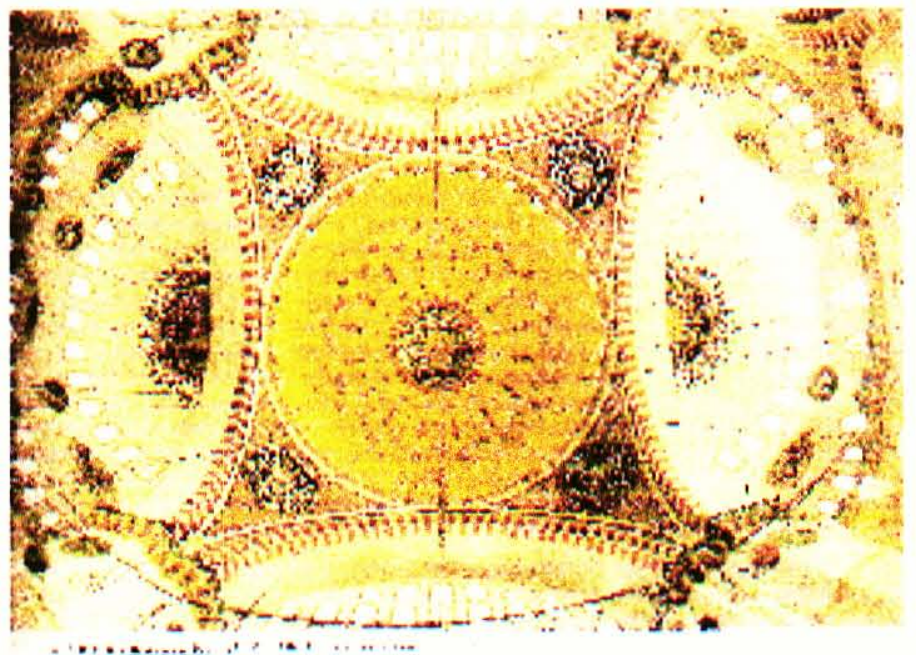

Figure 59. Süleymaniye Camii, Istanbul (1550-57) Interior of central dome and semidomes.

Two semidomes along the central axis lead to the qibla, but the sides are broken into a grander cascade of domes, including five on either side of the main dome following the central axis. The added domes appear to lighten the structure even further than the four semidomes of the Sehzade. ${ }^{169}$ Central to the construction is the massive 26.2 meter diameter main dome rivaling that of Hagia Sophia, barely surpassing the Fatih which had stood unrivaled for 100 years, and soaring 53 meters high. It is the apex of a cascade of more than 500 domes within the complex. ${ }^{170}$

\footnotetext{
169 Blair and Bloom 222.

170 "Suleymaniye Complex," Archnet <http://archnet.org/library/sites/onesite.tcl?site_id=3004>
} 


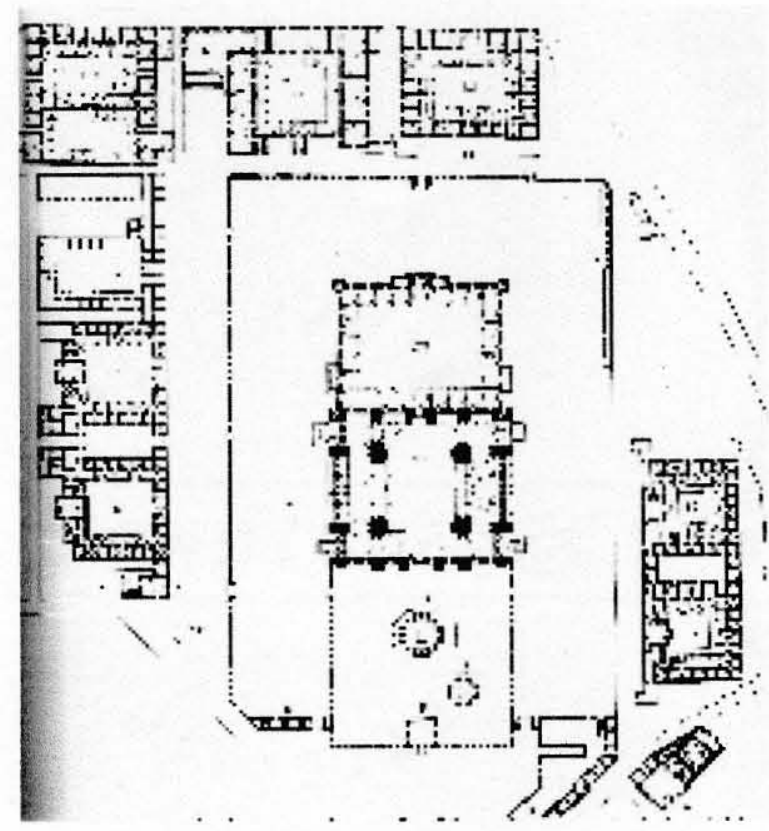

Figure 60. Süleymaniye Camii, Istanbul (1550-57) Plan.

The Süleymaniye is really Sinan's structural criticism of Hagia Sophia. Most notably, the Süleymaniye depends upon its simplicity and graceful silhouette for its beauty. The precise geometry of the plans meant that the purity of the form would not be interrupted by further support construction or worse, a failure of structural integrity. Sinan knew firsthand the damage that could be caused by uneven support. He had studied Hagia Sophia and understood that the additional buttressing necessary to keep it standing detracted from its original beauty.

The glittering mosaics found in Byzantine churches were unnecessary in the mosque, but some tile decoration of vegetal motifs in turquoise, blue, red, and white, created at Iznik, was used sparingly. ${ }^{171}$ Sinan did away with the arcaded screens separating the aisles from the nave, creating

\footnotetext{
171 John Freely and Augusto Romano Burelli, Sinan: Architect of Suleyman the Magnificent and the ottoman Golden Age 27-30.
} 


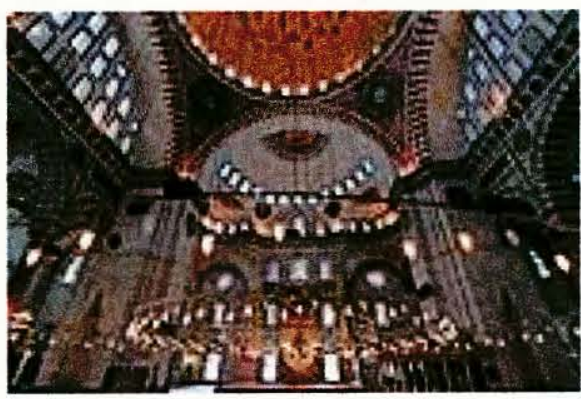

Figure 61. Süleymaniye Camii, Istanbul (1550-57) Interior of prayer hall.
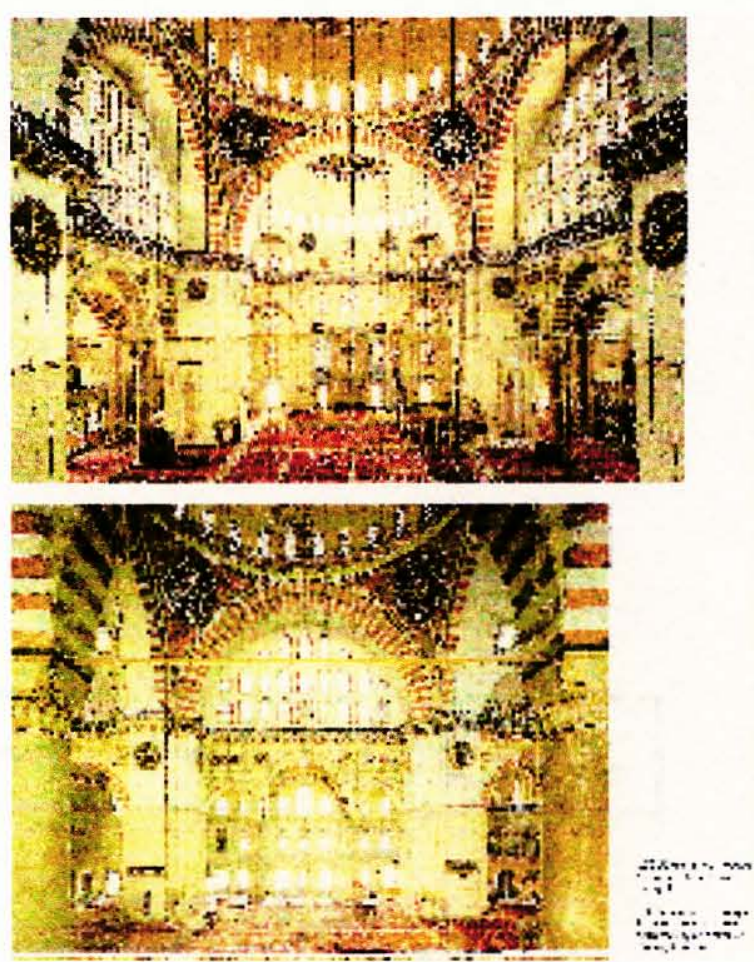

Figure 62. Süleymaniye Camii, Istanbul (1550-57) Interior.

a sanctuary which is part of a unified whole. There are side aisles, but they are only separated from the central space of the prayer hall by the four piers supporting the domes, and two pairs of porphyry columns which support the tympanum walls. ${ }^{172}$ All of the admiration and respect for the 172 John Freely and Augusto Romano Burelli, Sinan: Architect of Suleyman the Magnificent and the ottoman Golden Age 27. 
architecture of Hagia Sophia had inspired Sinan not only to achieve the mastery necessary to replicate it, but to achieve the mastery necessary to improve upon, respond to, and surpass it. The Süleymaniye Mosque was Sinan's final response to the architecture of Hagia Sophia. ${ }^{173}$ "With the Süleymaniye, Ottoman architecture attained a sophistication and maturity that represents the culmination of an effort to achieve an open and balanced composition of structure and form."174 Aptullah Kuran points out: "Considering that the St. Peter's Cathedral in Rome took 160 years from Bramante to Bernini, the completion of the Istanbul suileymaniye in seven shows the wealth of the Empire and the speed and efficiency with which the Corps of Court Architects performed their duty."175

\section{A New Fâtih}

The Fâtih Camii came full circle as both a beginning and an end to the 16th century Classical Ottoman style. Sultan Mustafa III ordered the reconstruction of the Fâtih on the foundations of the old mosque, after its collapse in the 1766 earthquake. The new structure took 5 years to build and incorporated some surviving elements of the original mosque including the three wings of the courtyard, the main portal, the mihrab, and the lower sections of the minarets. ${ }^{176}$

\footnotetext{
$\overline{173}$ Dogan Kuban, "The Style of Sinan's Domed Structures," 84.

174 Jale Erzen, "Sinan as Anti-Classicist" Mugarnas vol.5, (1988) 76 .

${ }^{175}$ John Freely and Augusto Romano Burelli, Sinan: Architect of Suleyman the Magnificent and the ottoman Golden Age 45.

${ }^{176}$ "Fatih Complex," Archnet <http://archnet.org/library/sites/onesite.tcl?site_id=2958>
} 


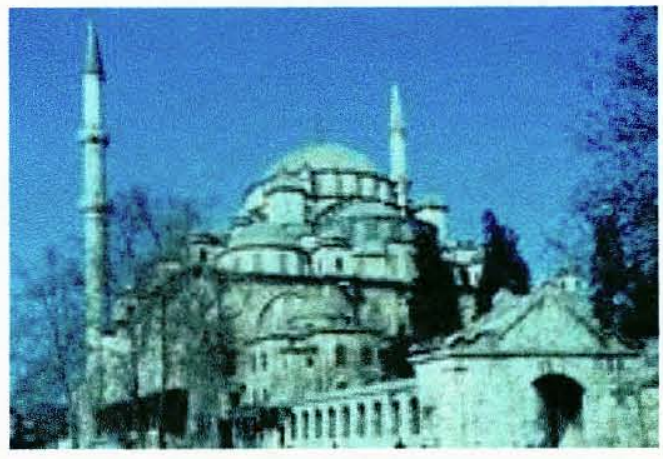

Figure 63. Fâtih Camii, Istanbul (1766-1771) Exterior.

The new Fâtih Camii was built between 1766 and 1771 by architect Mehmed Tahir. The reconstruction was executed in the sixteenth century style rather than the Baroque style in vogue at the time. The original form was unappealing in comparison to the architectural achievements of Sinan, so Mustafa III rebuilt the Fâtih in the Classical Ottoman style following the plan of the Sehzade Camii.

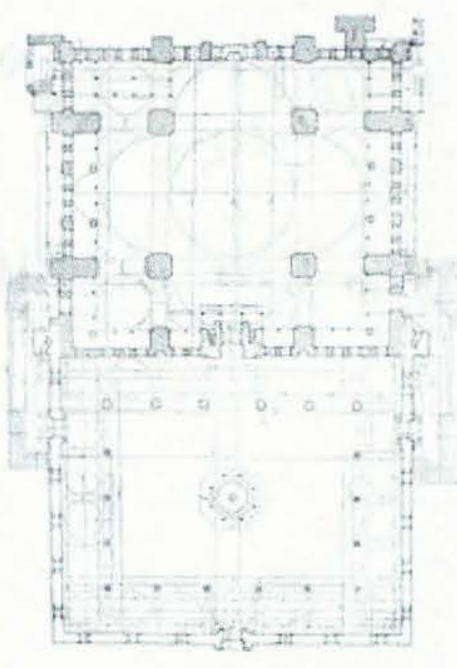

Figure 64. Fâtih Camii, Istanbul (1766-1771) Plan.

This, in effect, fulfilled the destiny it began as one of the great innovative imperial ottoman mosques. Details within the mosque however, "were executed in the Baroque style, as 
was the interior stenciling." ${ }^{177}$

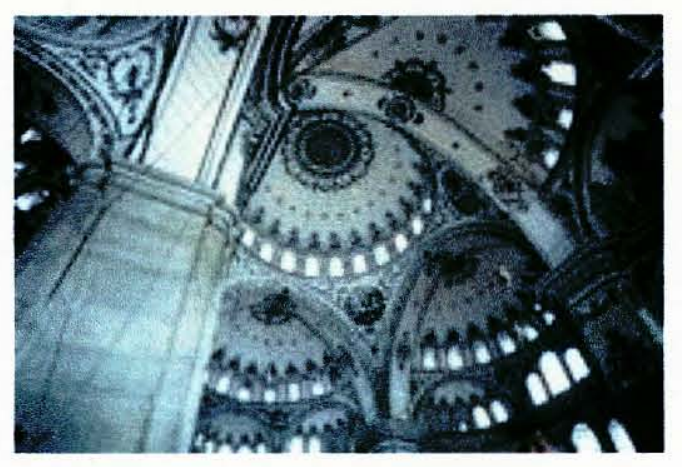

Figure 65. Fâtih Camii, Istanbul (1766-1771) Interior looking up at domes over the prayer hall.

The new Fâtih Camii was built slightly wider than the old one so that the area inside the mosque would equal the area of the preceeding courtyard. The central dome is supported by four semi-domes in the tradition of the Sehzade Camii. Four smaller domes top the corners of the mosque, completing the pyramidal cascade. ${ }^{178}$

\footnotetext{
177 "Fatih Mosque, Mehmed IIs foundation," Grove Dictionary of Art Online

178 "Fatih Complex," Archnet <http://archnet.org/library/sites/onesite.tcl?site_id=2958>
} 


\section{CHAPTER VII}

THE OTTOMAN ARCHITECTURAL CONQUEST OF CONSTANTINOPLE

\section{Respect and Rivalry}

Following the conquest of Constantinople in 1453 by the Ottomans, a new trend in architecture developed that achieved a balance between traditional ottoman building practices of Bursa and Edirne with the styles found in Byzantium and the West. An examination of the resources available to the Ottoman sultans and their architects yields clues to just what is ottoman about imperial ottoman architecture in 16th century Istanbul. The Ottomans drew from a variety of sources in their creation of a new classical architectural style which, grounded in Islamic tradition, continues to dominate the landscape of Istanbul.

The House of the Prophet in Medina, Arabia served as the first mosque. The plan of that structure influenced the development of mosques thereafter. However, rather than remain restricted by flat roofed hypostyle halls, Muslim architects began experimenting with domed structures. While retaining such architectural elements as the mihrab, minbar, minarets, fountain, and courtyard, the ottomans were able to create a new architectural style. Early attempts at spanning large central prayer spaces began with the Üç Serefeli Camii (1437-47). The rise of the empire allowed the Ottomans to combine their knowledge of this basic form with the building techniques of the Byzantines and the Europeans in their 
development of a more open, complex, and larger mosque structure. The path toward progress was focused on the objective of covering a centrally planned mosque with a large central dome covering a prayer hall which was uninterrupted by columns or other structural elements.

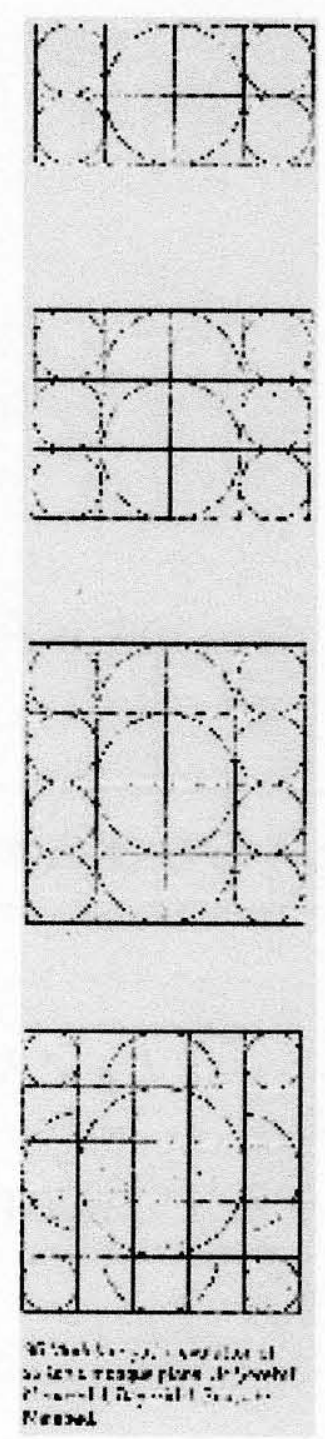

Figure 66. Transformation of mosque plans from the Üç Serefeli (top), Original Fâtih (upper middle), Sultan Bayezid II (lower middle), through the sehzade (bottom). 
What the Ottoman mosques discussed in this thesis have in common is an emphasis on a single unified interior space. While the cascade of domes on the exterior of the mosques creates beautiful silhouettes, it is the interior effect of those domes and semi-domes which is most important, both aesthetically and architecturally. In Ottoman mosques the focus is on interior space and not exterior space as evidenced by façades which face inward onto enclosed courtyards. This is especially fortunate in the crowded metropolitan cities of today where adjacent buildings are built right up against the exterior walls of the mosques, effectively hiding them from passersby. This also contributes to the sanctuary effect of the interior courtyard and the prayer hall. ${ }^{179}$

The conquest of Constantinople was more than a significant military defeat. The city contained architectural jewels which would influence the construction of Ottoman mosques. The centerpiece of Byzantine religious architecture still stands amid the great Ottoman centers of religious worship. Hagia Sophia earned the respect of Muslim rulers who sought to rival its magnificent architecture in the grand mosques of the Fâtih, Sultan Bayezid II, Sehzade, and Süleymaniye.

The "domed-square unit" is not unique to Ottoman Turkish architecture. It was also used in the architecture of the Sassanians, the Armenians, and the Byzantines, and "constituted the focal point of the centrally planned Greekcross church and the domed basilica", in addition to being "used by other peoples of Islamic faith though not as the 179 Ernest J. Grube, "What is Islamic Architecture," Ed. George Michell Architecture of the Islamic World (London: Thames and Hudson, 1978) 10-11. 
basic unit of their architecture."180 The Ottomans, however, through the work of Sinan in the sixteenth century and his predecessors, achieved a new monumental mosque architecture which culminated in the Classical Ottoman tradition at the Süleymaniye Camii in Istanbul.

The Süleymaniye Camii and complex combined the basic elements of worship seen in the Mosque of the Prophet, the design themes adopted from early Turkish mosques, and the Byzantine influence of the semidome as a buttress for central domes with the fundamentals of ideal Renaissance planning. Sinan developed a new standard of distinctly Ottoman architecture in his creation of the sixteenth century classical Ottoman architectural style. The embodiment of cross-cultural influences, this mosque marks the zenith of Ottoman mosque architecture in Istanbul.

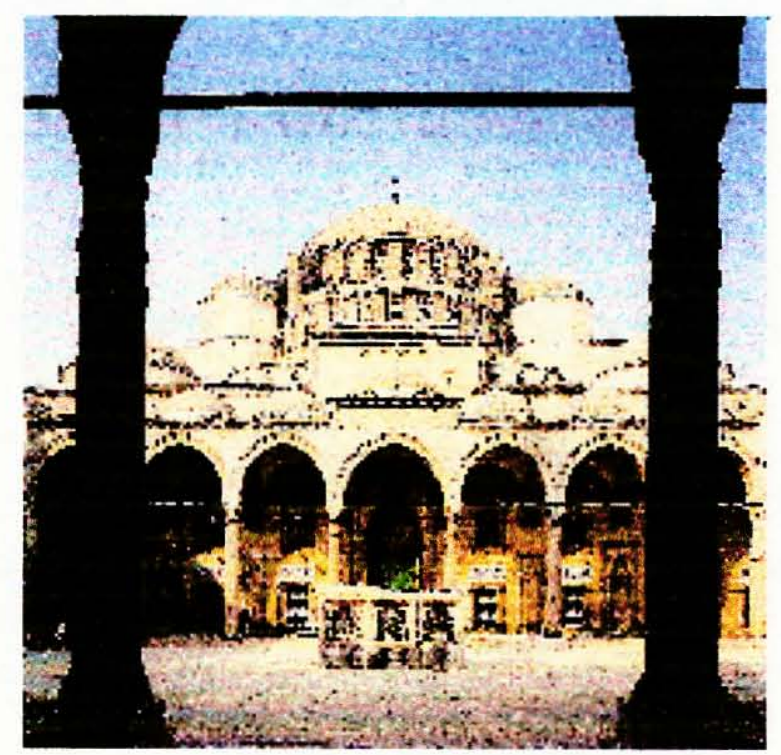

Figure 67. Süleymaniye Camii, Istanbul (1550-57) Façade from courtyard.

$\overline{180}$ Aptullah Kuran, The Mosque in Early Ottoman Architecture 27. 
REFERENCES

Ahunbay, M. and Z. Ahunbay. "Structural Influence of Hagia Sophia on Ottoman Mosque Architecture." Hagia Sophia. Eds. R. Mark and A. Cakmak. New York: Cambridge University Press, 1992.

Aslanapa, oktay. Turkish Art and Architecture. New York: Praeger Publishers, 1971.

Babinger, Franz. Mehmed the Conqueror and His Time. Princeton: Princeton University Press, 1978.

Blair, Sheila S. and Jonathan M. Bloom. The Art and Architecture of Islam 1250-1800. New Haven: Yale University Press, 1994.

"Constantine Lips." Ecumenical Patriarchate of Constantinople Website <http://www.patriarchate.org/ ecumenical_patriarchate/chapter_4/html/ constantine_lips.html>

Dündar, Argun. Edirne. Istanbul: The Award Ceremony Local Office, 1983. <http://archnet.org/library/documents/onedocument.tcl?document_id=3701>.

"Edirne." The Encyclopedia of Islam. Brill <http://www. 
encislam.brill.nl/data/EncIslam/CO/COM-0200.html>.

Erzen, Jale. "Sinan as Anti-Classicist." Mugarnas. Vol. 5. 1988 .

Ettinghausen, Richard, Oleg Grabar, and Marilyn JenkinsMadina. The Art and Architecture of Islam, 650-1250, 2nd ed. New Haven: Yale University Press, 2001.

"Fatih Complex." Archnet <http://archnet.org/library/sites/ one-site.tcl?site_id=2958>

"Fatih Mosque, Mehmed IIs foundation." Grove Dictionary of Art Online

"Fethiye Mosque." Archnet <http://archnet.org/library/sites/ one-site.tcl?site_id=7171>

Freely, John and Ahmet S. Cakmak. Byzantine Monuments of Istanbul. New York: Cambridge University Press, 2004.

Freely, John and Augusto Romano Burelli. Sinan: Architect of Suleyman the Magnificent and the Ottoman Golden Age. New York: Thames and Hudson, 1992.

Goodwin, Godfrey. A History of Ottoman Architecture. Baltimore: The Johns Hopkins Press, 1971.

"Green Mosque," ArchNet <http://archnet.org/library/sites/ one-site.tcl?site_id $=2883>$. 
Grube, Ernest J. "What is Islamic Architecture." Ed. George Michell. Architecture of the Islamic World. London: Thames and Hudson, 1978.

"Haci Ivaz Pasa." <http://archnet.org/library/parties/oneparty.tcl?party_id=627>

"Hagia Sophia." Archnet <http://archnet.org/library/sites/ one-site.tcl?site_id=2966>

"Hagia Sophia." Grove Dictionary of Art Online

"Ivvan." The Dictionary of Islamic Architecture. 1996. <http://archnet.org/library/dictionary/entry.tcl? entry_id=DIA0162>.

Kleinbauer, w. Eugene. Saint Sophia at Constantinople. Dublin, New Hampshire: William L. Bauhan, Publisher, 1999.

Krautheimer, Richard. Early Christian and Byzantine Architecture. New York: Viking Penguin, 1986.

Kritovoulos. History of Mehmed the Conqueror. Trans. C. Riggs. Greenwood Publishers, 1970.

Kuban, Dogan. Muslim Religious Architecture Part I: The Mosque and its Early Development. Leiden: E. J. Brill, 1974. 
---. Muslim Religious Architecture Part II: Development of Religious Architecture in Later Periods. Leiden: E. J. Brill, 1985 .

---. "The style of Sinan's Domed structures." Muqarnas. Vol. 4. 1987 .

"Kucuk Ayasofya Mosque." Archnet <http://archnet.org/library/ sites/one-site.tcl?site_id=7343>

Kuran, Aptullah. The Mosque in Early Ottoman Architecture. Chicago: The University of Chicago Press, 1968.

---. "Turkish Architecture, Past and Present: A Brief Account." Conservation as Cultural Survival. Ed. Renata Holod. Philadelphia: The Aga Khan Award for Architecture, 1980. <http://archnet.org/library/ documents/one-document.tcl?document_id=2605>.

---. "A Spatial Study of Three Ottoman Capitals: Bursa, Edirne, and Istanbul." Mugarnas Volume XIII: An Annual on the Visual Culture of the Islamic World. Ed. Gülru Necipoglu. Leiden: E. J. Brill, 1996. <http://archnet.org/library/documents/onedocument.tcl?document_id=5202>.

Mack, Rosamond. Bazaar to Piazza: The Islamic Trade and Italian Art 1300-1600. Berkeley: University of California Press, 2002. 
Mainstone, Rowland J. Hagia Sophia: Architecture, Structure, and Liturgy of Justinian's Great Church. New York: Thames and Hudson, 1988.

Mango, C. "Byzantine Writers on the Fabric of Hagia Sophia." Hagia Sophia. Eds. R. Mark and A. Cakmak. New York: Cambridge University Press, 1992.

Mathews, Thomas. Byzantine Churches of Istanbul: A Photographic Survey. University Park: The Pennsylvania State University Press, 1976.

---. The Early Churches of Constantinople: Architecture and Liturgy. University Park: The Pennsylvania State University Press, 1971.

"Mehmed II." Grove Dictionary of Art Online

Necipoglu, Gülru. The Age of Sinan: Architectural Culture in the Ottoman Empire. Princeton: Princeton University Press, 2005.

---. "Challenging the Past: Sinan and the Competitive Discourse of Early Modern Architecture." Mugarnas. Vol. 10. 1993.

---. "The Life of an Imperial Monument: Hagia Sophia after Byzantium." Hagia Sophia. Eds. R. Mark and A. Cakmak. New York: Cambridge University Press, 1992. 
Orbay, Iffet. Bursa. Istanbul: The Awards Ceremony Local Office, 1986. <http://archnet.org/library/documents/onedocument.tcl?document_id=3704>.

"Pammakaristos." Ecumenical Patriarchate of Constantinople Website <http://www.patriarchate.org/ecumenical_ patriarchate/chapter_4/html/pammakaristos.html>

Raby, Julian. "East and West in Mehmed the Conqueror's Library." Bulletin du Bibliophile. 1987.

--- "Pride and Prejudice: Mehmed the Conqueror and the Italian Portrait Medal." Italian Medals: Studies in the History of Art. Ed. J.G. Pollard. Hanover: University Press of New England, 1987.

---. "A Sultan of Paradox: Mehmed the Conqueror as a Patron of the Arts." Oxford A.J. Vol. 14. No. 1. 1982.

"St. Mary Pammakaristos." Grove Dictionary of Art Online

"Sergius." Ecumenical Patriarchate of Constantinople Website <http://www.patriarchate.org/ecumenical_patriarchate/ chapter_4/html/sergius_and_bacchus.html>

"Suleymaniye Complex." Archnet <http://archnet.org/library/ sites/one-site.tcl?site_id=3004>

"Sultan Bayezid II Complex." Archnet <http://archnet.org/ library/sites/one-site.tcl?site_id=7707> 
"Uc Serefeli Mosque" ArchNet <http://archnet.org/library/ sites/one-site.tcl?site_id=2910>. 


\section{CURRICULUM VITAE}

NAME: Shannon Phifer Carneal

$\begin{array}{ll}\text { ADDRESS: } & 111 \text { Sweetbriar Lane } \\ & \text { Louisville, KY } 40207\end{array}$

EDUCATION: Honors Diploma

Ballard High School

1991-1995

Rhodes College

1995-1997

Murray State University

KIIS Program, Italy

1998

B.A., History

Bellarmine University

1997-1999

M.A., Fine Arts, Art History

University of Louisville

2002-2005 